UNIVERSIDADE DE BRASÍLIA

FACULDADE DE CIÊNCIAS DA SAÚDE

PROGRAMA DE PÓS-GRADUAÇÃO EM CIÊNCIAS FARMACÊUTICAS

JORGE ANTONIO CHAMON JÚNIOR

CARACTERIZAÇÃO DOS ISOLADOS CLÍNICOS DE CRYPTOCOCCUS SPP. E DETERMINAÇÃO DE SUA SENSIBILIDADE À ANTIFÚNGICOS E AO EXTRATO DE EUGENIA DYSENTERICA 
JORGE ANTONIO CHAMON JÚNIOR

\section{CARACTERIZAÇÃO DOS ISOLADOS CLÍNICOS DE CRYPTOCOCCUS SPP. E DETERMINAÇÃO DE SUA SENSIBILIDADE À ANTIFÚNGICOS E AO EXTRATO DE EUGENIA DYSENTERICA}

Dissertação apresentada ao Programa de Pós-graduação em Ciências Farmacêuticas da Faculdade de Ciências da Saúde, Universidade de Brasília, como requisito parcial à obtenção do título de Mestre em Ciências Farmacêuticas.

Orientadora: Prof ${ }^{\mathrm{a}}$. Dra ${ }^{\mathrm{a}}$. Yanna Karla de Medeiros Nóbrega

BRASÍLIA

2016 
Chamon Júnior, Jorge Antonio
CC448 Caracterização dos isolados clínicos de Cryptococcus spp. e determinação de sua sensibilidade à antifúngicos e ao extrato de Eugenia dysenterica / Jorge Antonio Chamon Júnior; orientador Yanna Karla de Medeiros Nóbrega. -- Brasilia, 2016.

$71 \mathrm{p}$.

Dissertação (Mestrado - Mestrado em Ciências Farmacêuticas) -- Universidade de Brasilia, 2016.

1. Cryptococcus neoformans. 2. Cryptococcus gattii. 3. Eugenia dysenterica. 4. Atividade antifúngica. I. de Medeiros Nóbrega, Yanna Karla, orient. II. Título. 
CARACTERIZAÇÃO DOS ISOLADOS CLÍNICOS DE CRYPTOCOCCUS SPP. E DETERMINAÇÃO DE SUA SENSIBILIDADE À ANTIFÚNGICOS E AO EXTRATO DE EUGENIA DYSENTERICA

Dissertação apresentada ao Programa de Pós-graduação em Ciências Farmacêuticas da Faculdade de Ciências da Saúde, Universidade de Brasília, como requisito parcial à obtenção do título de Mestre em Ciências Farmacêuticas.

Aprovada em 09 de dezembro de 2016.

\section{BANCA EXAMINADORA}

Profa. Dr ${ }^{\mathrm{a}}$. Yanna Karla de Medeiros Nóbrega

Universidade de Brasília (UnB)

Prof. Dr. André Moraes Nicola

Universidade de Brasília (UnB)

Prof. Dr. Fabiano José Queiroz Costa

Hospital Universitário de Brasília (HUB) 
Dedico este empenho realizado a minha família, aos meus amigos e a aqueles que lutam por dias melhores. 


\section{AGRADECIMENTOS}

A Deus por iluminar a vida de meus entes queridos com saúde e paz no coração.

À minha esposa por todo apoio, dedicação, carinho, incentivo, paciência e amor recíproco.

Aos meus filhos César e Vitor por me fazer acreditar no real sentido da vida.

À minha mãe, irmã e vó pela dedicação e zelo em toda minha formação como ser humano e profissional.

À minha grande família, pela convivência, relações humanísticas e completo apoio de sempre.

Aos amigos queridos, de perto e de longe, a minha eterna gratidão e companheirismo sem fins individualistas e lucrativos.

A minha orientadora Yanna por sua conduta transparente, colaborativa e norteadora durante todo este processo.

Aos meus colegas de trabalho do Laboratório Central de Saúde Pública do Distrito Federal (LACEN-DF), especialmente a servidora e amiga Amabel Fernandes Correia por toda injeção de ânimo e por me julgar apto a este desafio.

Aos meus superiores hierárquicos Graziela Araújo e Eduardo Filizzola, por todo incentivo.

Aos meus mestres e professores, muito obrigado pelo conhecimento difundido, lições de vida e aprendizado técnico.

Aos meus alunos que sempre me incentivaram pela busca da informação fidedigna e aplicada aos diversos contextos da vida.

A todos que duvidaram de minha capacidade, muito obrigado, pois vocês foram combustíveis ilimitados para minhas atividades.

A todos que acreditaram no meu potencial, nas minhas atividades laborais, nas minhas ideias, nos meus devaneios, principalmente quando nem eu mais acreditava.

Sem todas esses auxílios e demonstrações afetivas, nada disso seria possível. 


\section{RESUMO}

CHAMON JÚNIOR, Jorge Antonio. CARACTERIZAÇÃO DOS ISOLADOS CLÍNICOS DE CRYPTOCOCCUS SPP. E DETERMINAÇÃO DE SUA SENSIBILIDADE À ANTIFÚNGICOS E AO EXTRATO DE EUGENIA DYSENTERICA, 2016. Dissertação (Mestre em Ciências Farmacêuticas) - Faculdade de Ciências da Saúde, Universidade de Brasília, Brasília, 2016.

Introdução: A criptococose vem assumindo um papel relevante dentre as infecções fúngicas oportunistas por ser considerada uma das micoses mais comuns nos indivíduos imunodeprimidos apresentando elevada morbidade e mortalidade, com cerca de 650.000 mortes por ano em todo mundo. Esta doença é causada pelos fungos leveduriformes encapsulados Cryptococcus neoformans e Cryptococcus gattii. O C. neoformans acomete pacientes imunocomprometidos, já o $C$. gattii, vem se tornando um grave problema de saúde pública, pois é capaz de acometer pacientes imunocompetentes. Fato que promove ainda mais preocupação é o fato de existir escassos medicamentos antifúngicos disponíveis, que possuem elevada toxicidade e já apresentam resistência por mecanismos pouco elucidados. Diante destas circunstâncias, estratégias farmacológicas vem sendo estudadas e desenvolvidas, inclusive empregando extratos de plantas com potencial terapêutico. Neste sentido, o estudo do efeito antifúngico do extrato aquoso das folhas de Eugenia dysenterica (Mart.) DC sobre isolados de Cryptococcus spp foi realizado.

Objetivos: Identificar isolados clínicos de Cryptococcus spp. por métodos clássicos, bioquímicos, manuais e automatizados, moleculares e por espectrometria de massa, visando caracterizá-los fenotipicamente e genotipicamente, e avaliar o perfil de susceptibilidade aos agentes antifúngicos convencionais e ao extrato aquoso bruto de Eugenia dysenterica.

Materiais e métodos: Neste estudo, 20 isolados clínicos contendo Cryptococcus spp. foram submetidos a identificações microscópicas (tinta nanquim e hidróxido de potássio), provas bioquímicas manuais (assimilação de glicina, produção de urease e melanina), provas bioquímicas automatizadas, PCR-RFLP e espectometria de massa (MALDI-TOF). Além disso, foi realizado teste de suscetibilidade a antifúngicos convencionais e microdiluição em placa para o extrato aquoso de folhas de E. dysenterica.

Resultados: A partir da diversas metodologias empregadas obtivemos a caracterização das espécies (12 C. neoformans e 8 C. gattii) e variantes (12 VNI e 8 VGII), assim como a presença de resistência aos antifúngicos usuais (3 casos de resistência a Anfotericina B). Além da demonstração do efeito antifúngico do extrato de E. dysenterica.

Conclusão: Neste estudo, visualizou-se o predomínio da espécie $C$. neoformans VNI frente a C. gattii VGII, em consonância com os estudos já realizados e as informações epidemiológicas existentes, e que esta caracterização é fundamental para fins terapêuticos e de saúde pública, diante do quadro de limitação de tratamento e iminentes casos de resistências a antifúngicos. Além disso, fornece subsídios para que o extrato aquoso de $E$. dysenterica seja considerado a um forte canditado na elaboração de novos fármacos antifúngicos.

Palavras chaves: Cryptococcus neoformans, Cryptococcus gattii, Eugenia dysenterica, atividade antifúngica 


\begin{abstract}
CHAMON JÚNIOR, Jorge Antonio. CHARACTERIZATION OF THE CLINICAL ISOLATES OF CRYPTOCOCCUS SPP. AND DETERMINATION OF ITS SENSITIVITY TO ANTIFUNGS AND THE EXTRACT OF EUGENIA DYSENTERICA, 2016. Dissertation (Master in Pharmaceutical Sciences) - Faculty of Health Sciences, University of Brasília, Brasília, 2016.
\end{abstract}

Introduction: Cryptococcosis has been playing an important role among fungal opportunistic infections, being considered one of the most common mycoses in immunocompromised individuals presenting high morbidity and mortality, with around 650,000 deaths per year worldwide. This disease is caused by the encapsulated yeast Cryptococcus neoformans and Cryptococcus gattii. C. neoformans affects immunocompromised patients, and $C$. gattii has become a serious public health problem since it is capable of injuring immunocompetent patients. A fact that promotes even more concern is the fact that there are few antifungal drugs available, which present high toxicity and are already resistant by poorly elucidated mechanisms. Facing these circumstances, pharmacological strategies have been studied and developed, including using plants with therapeutic potential in their extracts. In this sense, the study of the antifungal effect of the aqueous extracts of Eugenia dysenterica (Mart.) DC leaves on Cryptococcus spp isolates was performed.

Objectives: To identify clinical isolates of Cryptococcus spp. by classical, biochemical manual and automated, molecular and mass spectrometry methods, aiming to characterize them phenotypically and genotypically. Added to this is the assessment of the susceptibility profile to the conventional antifungal agents and to the crude aqueous extract of Eugenia dysenterica.

Materials and methods: In this study, 20 clinical isolates containing Cryptococcus spp. (Glycine assimilation, urease and melanin production), automated biochemical tests, PCRRFLP and mass spectrometry (MALDI-TOF) were performed. In addition, the antifungal susceptibility test and plaque microdilution for the aqueous extract of leaves of $E$. dysenterica were performed.

Results: Based on the different methodologies used, we characterized the species (12 $C$. neoformans and 8 C. gattii) and variants (12 VNI and $8 \mathrm{VGII})$, as well as the presence of resistance to the usual antifungal agents (3 cases of resistance to Amphotericin B). In addition to demonstrating the antifungal effect of E. dysenterica extract.

Conclusion: In this study, the prevalence of the $C$. neoformans VNI species in relation to $C$. gattii VGII was observed, in agreement with the studies already carried out and the existing epidemiological information, and that this characterization is fundamental for therapeutic and public health purposes, In view of the limitation of treatment and imminent cases of antifungal resistance. In addition, it provides subsidies for the aqueous extract of $E$. dysenterica to be considered a strong candidate in the development of new antifungal drugs.

Key words: Cryptococcus neoformans, Cryptococcus gattii, Eugenia dysenterica, antifungal activity 


\section{LISTA DE FIGURAS}

Figura 1 - Estruturas celulares de leveduras do gênero Cryptococcus ................................ 13

Figura 2 - Forma celular de Cryptococcus spp........................................................... 19

Figura 3 - Técnica de microscopia ótica para visualização de Cryptococcus spp ….............. 21

Figura 4 - Colônias de Cryptococcus spp. em meios de cultivo .......................................... 22

Figura 5 - Crescimento de Criptococcus spp. em ágar CGB …...................................... 22

Figura 6 - Identificação bioquímica de Cryptococcus spp. em meio ureia-ágar-base ............ 23

Figura 7 - Flores e frutos de Eugenia dysenterica (Mart.) DC ......................................... 28

Figura 8 - Visualização microscópica de Cryptococcus spp. .............................................. 39

Figura 9 - Aspectos macroscópicos Cryptococcus spp. em meios de cultura ......................... 41

Figura 10 - Espectros de Cryptococcus na plataforma VITEK MS .................................... 43 


\section{LISTA DE TABELAS}

Tabela 1 - Espécies atuais e propostas para o complexo C. gattii e C. neoformans 15

Tabela 2 - Isolados clínicos de pacientes com suspeita de micoses sistêmicas 30

Tabela 3 - Teste de identificação bioquímica para Cryptococcus spp. 31

Tabela 4 - Cepas de referência do complexo Cryptococcus spp. 34

Tabela 5 - Características microscópicas das amostras biológicas por exame direto 39

Tabela 6 - Resultados dos testes bioquímicos manuais...... 40

Tabela 7 - Técnicas utilizadas na identificação de Cryptococcus spp. 44

Tabela 8 - ECV para drogas antifúngicas usadas no tratamento da criptococose 45

Tabela 9 - Resultados dos testes de susceptibilidade do Vitek 2 Compact 45

Tabela 10 - CIM de FLU (controle) e E. dysenterica. 46 


\section{LISTA DE ABREVIATURAS}

5-FC

AFLP

AIDS

CEP/SES-DF

CGB

CFW

CIM

CLSI

DMSO

$\mathrm{ECV}$

ELISA

FDA

FNT

GXM

LACEN-DF

LCR

MALDI-TOF

MLST

NPM

PAS

PCR

PCR fingerprint

PCR multiplex

PCR nested

$\mathrm{pH}$

qPCR

RFLP

SNC

Var

VG

VN 5-fluorocitosina

Amplified Fragment Length Polymorphism

Síndrome da Imudeficiência Adquirida

Comitê de Ética em Pesquisa da Secretaria de Estado de Saúde do DF

L-canavanina, glicina e azul de bromotimol

Branco de Calcoflúor

Concentração Inibitória Mínima

Clinical and Laboratory Standards Institute

Dimetilsulfóxido

Epidemiologic Cutoff Value

Enzyme-Linked Immunosorbent Assay

Food and Drug Administration

Fator de Necrose Tumoral

Glucuronoxilomanana

Laboratório Central de Saúde Pública do Distrito Federal

Líquido cefalorraquidiano

Matrix Assisted Laser Desorption Ionization Time-of-flight

Multilocus sequence typing

Núcleo de Parasitologia e Micologia

Ácido periódico Schiff

Reação em Cadeia da Polimerase

Reação em Cadeia da Polimerase fingerprint

Reação em Cadeia da Polimerase multiplex

Reação em Cadeia da Polimerase nested

Potencial hidrogeniônico

Reação em Cadeia da Polimerase em Tempo Real

Restriction Fragment Length Polymorphism

Sistema Nervoso Central

Variedade

Variedade gattii

Variedade neoformans 


\section{SUMÁRIO}

1 INTRODUÇÃO

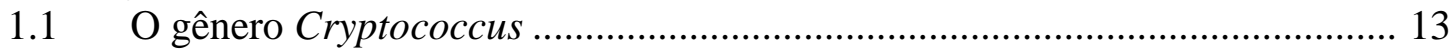

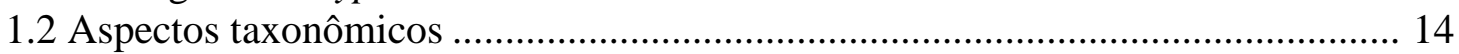

1.3 Fatores de virulência .............................................................................................. 15

1.4 Aspectos morfobioquímicos ............................................................................ 18

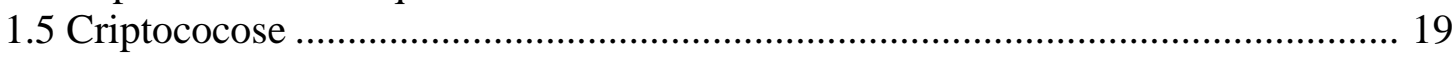

1.6 Diagnóstico laboratorial .................................................................................. 20

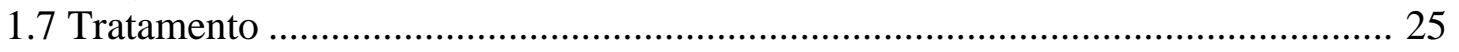

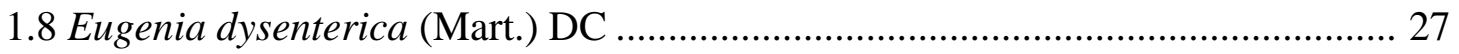

2 OBJETIVOS

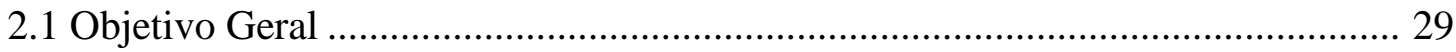

2.2 Objetivos Específicos .................................................................................... 29

\section{MATERIAL E MÉTODOS 29}

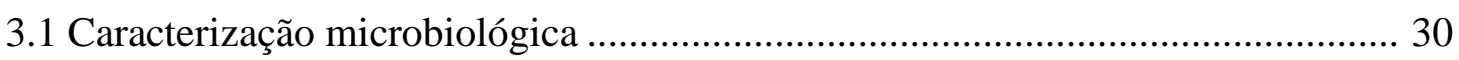

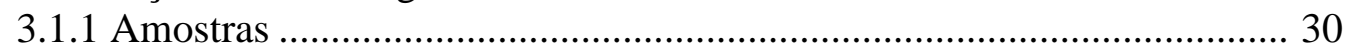

3.1.2 Exame direto................................................................................... 30

3.1.3 Isolamento fúngico............................................................................. 31

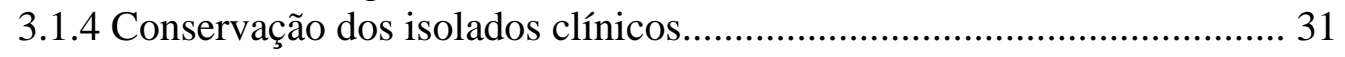

3.1.5 Testes bioquímicos manuais................................................................ 31

3.1.6 Testes bioquímicos automatizados........................................................ 32

3.1.7 Método molecular PCR-RFLP.............................................................. 32

3.1.7.1 Extração do DNA do Cryptococcus spp. ............................... 32

3.1.7.2 Método de PCR-RFLP............................................................. 33

3.1.8 Espectrometria de massa....................................................................... 34

3.2 Determinação do perfil de susceptibilidade de Cryptococcus spp........................ 35

3.2.1 Agentes antifúngicos..............................................................................35

3.2.2 Preparo do inóculo fúngico................................................................... 35

3.2.3 Leitura e interpretação dos resultados.................................................. 35

3.3 Avaliação da atividade antifúngica do extrato aquoso de Eugenia dysenterica.... 36

3.3.1 Material botânico.............................................................................. 36

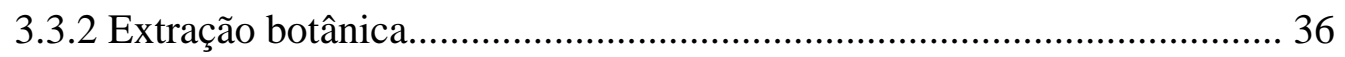

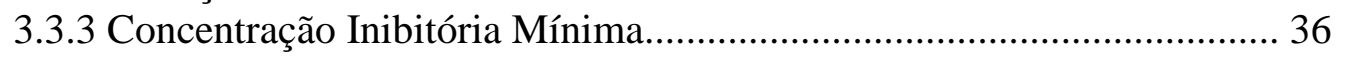

3.3.3.1 Preparação do meio de cultura............................................ 36

3.3.3.2 Preparo do inóculo fúngico........................................................ 37

3.3.3.3 Preparação da solução estoque................................................. 37

3.3.3.4 Preparação da placa.................................................................. 37

3.3.4 Leitura e interpretação dos resultados..................................................... 38

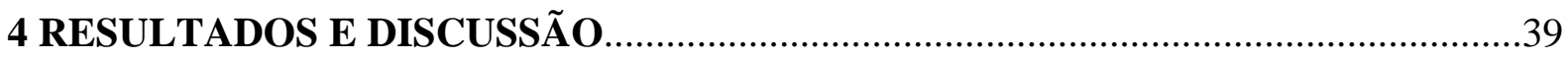

4.1 Características microbiológicas dos isolados clínicos............................................. 39

4.2 Perfil de susceptibilidade de Cryptococcus spp. ................................................. 44

4.3 Atividade antifúngica do extrato aquoso de Eugenia dysenterica .......................... 45

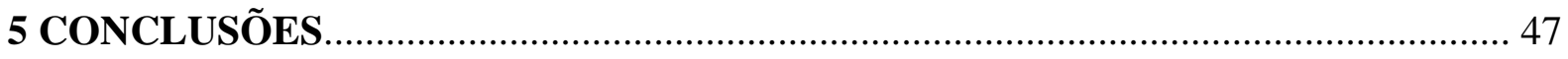




\section{INTRODUÇÃO}

\section{$1.1 \mathrm{O}$ gênero Cryptococcus}

O gênero Cryptococcus compreende fungos basidiomicetos, leveduriformes, encapsulados, embora existam formas acapsuladas ou deficientes em cápsulas, que apresentam tamanho entre 2 a $10 \mu \mathrm{m}$ de diâmetro (COSTA, 2009). Em geral, suas células são compostas de cápsula, parede celular, membrana celular, núcleo e citoplasma com organelas como: corpúsculo de Golgi, mitocôndria, ribossomo, retículo endoplasmático e vacúolo (Figura 1) (NAYAK et al., 2010).

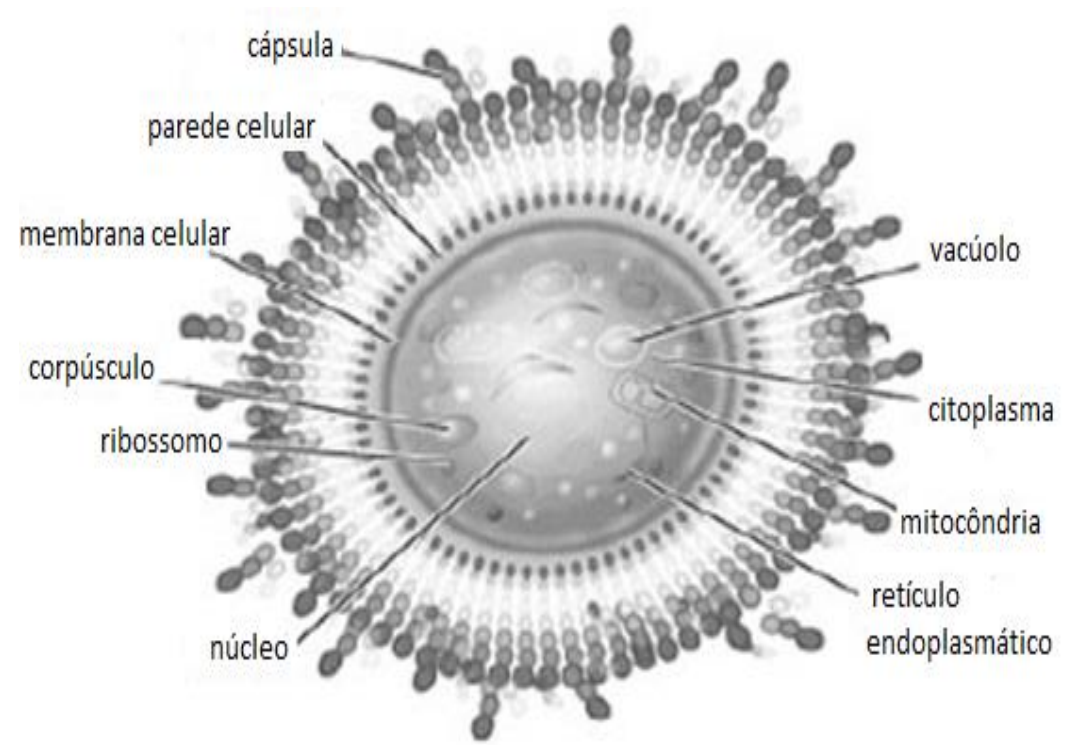

Figura 1 - Estrutura celular de levedura do gênero Cryptococcus Fonte: Adaptado de NAYAK et al., 2010

Existem cerca de 40 espécies de Cryptococcus, sendo a grande maioria de vida livre. As espécies patogênicas infectam mamíferos, aves e insetos, causando infecções sistêmicas e cutâneas. Dentre estas espécies destacam-se duas de grande impacto clínico: Cryptococcus neoformans e Cryptococcus gattii (ELLIS \& PFEIFFER, 1990; SORRELL, 2001).

Em relação ao $C$. neoformans, sabe-se que é um fungo cosmopolita e responsável pela maioria das infecções criptocócicas em indivíduos imunocomprometidos, sejam pacientes com Sindrome da Imudeficiência Adquirida (AIDS), aqueles submetidos a terapias imunossupressoras, transplantados, com doenças linfoproliferativas e desnutridos 
(FERNANDES et al., 2000; DARZÉ et al., 2000; COGLIATI, 2013; RIVERA et al., 2015; GUTCH et al., 2015).

Os principais reservatórios do C. neoformans são fezes de pombos e de outras aves, troncos ocos de diferentes espécies de árvores e guano (fezes de morcego acumuladas e empregadas como fertilizante), o que torna este fungo extremamente disseminado em diferentes tipos de ambientes (NWEZE et al., 2015).

No que se refere ao C. gattii, caracteriza-se como um fungo endêmico para as regiões tropicais e subtropicais, sendo responsável por até $80 \%$ das infecções criptocócicas em hospedeiros imunocompetentes (KWONG-CHUNG \& BENNETT, 1992; SORRELL, 2001; SMITH \& KAUFFMAN, 2012; PAULA et al., 2014), representando grave problema de saúde pública (CASADEVALL \& PERFECT, 1998; TRILLES et al., 2008).

C. gattii também apresenta nicho ecológico bastante diversificado, podendo estar presentes em troncos de árvores em decomposição, solo, água doce e salgada (KIDD et al., 2007; DATTA et al., 2009; BYRNES et al., 2009a; WALRAVEN et al., 2011). Entre as árvores em que há a presença de C. gattii destacam-se o Eucalyptus spp. (eucalipto), Abies spp. (abeto), Acer spp. (bordo), Alnus glutinosa (amieiro), Cedrus spp. (cedro), Pinus spp. (pinheiro) e Quercus spp. (carvalho) (SPRINGER \& CHATURVEDI, 2010), e em algumas espécies de cactos (LOPERENA-ALVAREZ et al., 2010).

No Brasil, a presença do C. neoformans ocorre em todas as regiões do país, divergindo em relação ao C. gattii, que se comporta como patógeno principalmente nas regiões Norte e Nordeste do país (TRILLES et al., 2008).

Outras espécies são raramente identificadas incluindo C. laurentii, C. albidus, $C$. uzbekistanensis, C. adeliensis, C. curvatus, C. magnus, C. humicolus, C. luteolus, C. macerans, C. flavescens e C. uniguttulatus (PEDROSO et al., 2007; LEITE JR et al., 2012).

\subsection{Aspectos taxonômicos}

O gênero Cryptococcus apresenta características genotípicas, epidemiológicas e genéticas que possibilitam classificá-lo em variedades, sorotipos e genótipos moleculares (ENANCHE-ANGOULVANT et al., 2007; BOVERS et al., 2008; HUSTON \& MODY, 2009). Observa-se que C. neoformans apresenta duas variedades, var. grubii (sorotipo A) e var. neoformans (sorotipo D), podendo haver um híbrido (sorotipo AD), já o C. gattii inclui 
sorotipos B e C (FRANZOT et al., 1997; MEYER et al., 2009; TELLO, et al., 2013; NÁGARAJHA SELVAN et al., 2014).

Com os avanços em estudos moleculares permitiu-se uma classificação mais detalhada, dividida em nove genótipos moleculares. O C. neoformans var. grubii classificado em VNI, VNII e VNB, o C. neoformans var. neoformans em VNIV, o híbrido em VNIII, $C$. gattii em VGI, VGII, VGIII, VGIV e VGV (LEVITZ \& BOEKHOUT, 2006; ENANCHEANGOULVANT et al., 2007).

O incremento de análises filogenéticas possibilita inferir que o $C$. gattii difere-se do $C$. neoformans em cerca de 37 milhões anos. Além disso, sugere que a var. grubii e a var. neoformans possuem uma diferença de aproximadamente 19 milhões de anos, conforme cálculos com base na média ponderada de divergência entre o aparecimento de dois genes codificadores de proteínas (XU et al., 2000; MARRA et al., 2004).

A junção de técnicas filogenéticas e de biologia molecular como Multilocus Sequence Typing (MLST), Amplified Fragment Length Polymorphism (AFLP), PCR fingerprint e Restriction Fragment Length Polymorphism (PCR-RFLP) permite a confecção de uma proposta, ainda que controversa, de alteração de nomenclatura das espécies atuais, criando a perspectiva de novas espécies como $C$. deneoformans, $C$. bacilliisporus, $C$. deuterogattii, $C$. tetragattii e $C$. decagattii, além de associações entre espécies e formas híbridas, Cryptococcus deneoformans x Cryptococcus gattii híbrido, Cryptococcus neoformans x Cryptococcus gattii híbrido e Cryptococcus deneoformans x Cryptococcus deuterogattii híbrido (Tabela 1) (HAGEN et al., 2015; NYAZIKA et al., 2016). 
Tabela 1 - Espécies atuais e propostas para o complexo C. gattii e C. neoformans

\begin{tabular}{|c|c|c|c|}
\hline $\begin{array}{l}\text { Nomenclatura da } \\
\text { espécie atual }\end{array}$ & $\begin{array}{l}\text { Clados obtidos por MLST / } \\
\text { Genótipos obtidos por AFLP }\end{array}$ & $\begin{array}{c}\text { PCR-fingerprint / } \\
\text { Genótipos obtidos por } \\
\text { RFLP }\end{array}$ & $\begin{array}{c}\text { Nomenclatura da espécie } \\
\text { proposta }\end{array}$ \\
\hline \multirow{3}{*}{$\begin{array}{c}\text { Cryptococcus } \\
\text { neoformans var. grubii }\end{array}$} & Clado F, AFLP1 & VNI & \multirow{3}{*}{ Cryptococcus neoformans } \\
\hline & Clado G, AFLP1A/VNB & VNII & \\
\hline & Clado H, AFLP1B & VNII & \\
\hline $\begin{array}{l}\text { Cryptococcus } \\
\text { neoformans var. } \\
\text { Neoformans }\end{array}$ & Clado I, AFLP2 & VNIV & Cryptococcus deneoformans \\
\hline $\begin{array}{c}\text { Cryptococcus } \\
\text { neoformans híbrido }\end{array}$ & AFLP3 & VNIII & $\begin{array}{c}\text { Cryptococcus neoformans } \mathrm{x} \\
\text { Cryptococcus deneofromans } \\
\text { híbrido }\end{array}$ \\
\hline \multirow{5}{*}{ Cryptococcus gattii } & Clado D, AFLP4 & VGI & Cryptococcus gattii \\
\hline & Clado C, AFLP5 & VGIII & Cryptococcus bacilliisporus \\
\hline & Clado A, AFLP6 & VGII & Cryptococcus deuterogattii \\
\hline & Clado E, AFLP7 & VGIV & Cryptococcus tetragattii \\
\hline & Clado B, AFLP10 & VGIV/GIIIc & Cryptococcus decagattii \\
\hline $\begin{array}{l}\text { Cryptococcus } \\
\text { neoformans var. } \\
\text { neoformans } \mathrm{x} \\
\text { Cryptococcus gattii } \\
\text { AFLP4/VGI híbrido }\end{array}$ & AFLP8 & & $\begin{array}{c}\text { Cryptococcus deneoformans } \\
\mathrm{x} \\
\text { Cryptococcus gattii híbrido }\end{array}$ \\
\hline $\begin{array}{c}\text { Cryptococcus } \\
\text { neoformans var. grubii x } \\
\text { Cryptococcus gattii } \\
\text { AFLP4/VGI híbrido } \\
\end{array}$ & AFLP9 & & $\begin{array}{l}\text { Cryptococcus neoformans } \mathrm{x} \\
\text { Cryptococcus gattii híbrido }\end{array}$ \\
\hline $\begin{array}{c}\text { Cryptococcus } \\
\text { neoformans var. } \\
\text { neofromans } \mathrm{x} \\
\text { Cryptococcus gattii } \\
\text { AFLP6/VGII híbrido }\end{array}$ & AFLP11 & & $\begin{array}{c}\text { Cryptococcus deneoformans } \\
\mathrm{x} \\
\text { Cryptococcus deuterogattii } \\
\text { híbrido }\end{array}$ \\
\hline
\end{tabular}

Fonte: Adaptado de HAGEN et al., 2015

1.3 Fatores de virulência

O gênero Cryptococcus apresenta inúmeros fatores de virulência, dos quais se destacam a habilidade de crescer a $37{ }^{\circ} \mathrm{C}$, a presença de cápsula, produção de melanina, urease, fosfolipase e proteases (STEENBERGEN \& CASADEVALL, 2003; PEDROSO et al., 2009; LIN, 2009; DOERING, 2009; EISENMAN \& CASADEVALL, 2012; PAULA, et al., 2014; LEV et al., 2016). Estes fatores são alvos de muitos estudos que visam identificar quais genes estão envolvidos no processo de virulência (OKABAYASHI et al., 2007; ROSA e 
SILVA et al., 2008) e são significativos para a determinação do grau de patogenicidade, assim como as características e estado imunológico do hospedeiro (REOLON et al., 2004).

A capacidade do Cryptococcus spp. em se desenvolver a $37{ }^{\circ} \mathrm{C}$ ou de ter termotolerância é fundamental, isso possibilita o crescimento e a multiplicação destes fungos à temperatura corporal dos mamíferos, entre 37 a $39^{\circ} \mathrm{C}$ (KWON-CHUNG \& BENNETT, 1992; CASADEVALL \& PERFECT, 1998; BARBOSA JÚNIOR et al., 2013).

A cápsula polissacarídica geralmente é composta por três componentes: manoproteína, galactoxilomanana e glucuronoxilomanana (GXM). A GXM é um polímero de alto peso molecular, responsável por cerca de $90 \%$ em massa, da constituição da estrutura capsular (STEENBERGEN et al., 2003). Esta estrutura confere uma morfologia única em relação a outras leveduras patogênicas, que irá proteger o fungo, dificultando a apresentação de antígenos para as células T, diminuindo a resposta imunológica do hospedeiro. Esta cápsula reduz a fagocitose, prejudicando a ação leucocitária, além de impedir a ligação dos receptores do sistema complemento aos leucócitos (COEJAERTS, 2006; PEDROSO, 2008).

A presença de melanina é importante para o fungo por atuar como um antioxidante, protegendo-o da destruição intracelular por células fagocíticas. Além disso, a produção de melanina impede a ação do fator de necrose tumoral alfa (TNF- $\alpha$ ) produzido por macrófagos ativados (WONG et al., 1990; CHATURVEDI et al., 1996; DOLANDES FRANCO, 2001). Por essas propriedade a melanina promove a resistência a radiação ultravioleta, a diminuição da susceptibilidade para anfotericina $\mathrm{B}$ e a resistência a agentes oxidantes (WANG \& CASADEVALL, 1994; WANG et al., 1995; SALAS et al, 1996; BARBOSA JÚNIOR et al., 2013).

A enzima urease é codificada pelo gene Urel e é secretada pelo fungo durante os quadros patológicos. Esta enzima participa do processo de interação patógeno-hospedeiro, aumentando o $\mathrm{pH}$, favorecendo principalmente a infecção pulmonar e a invasão do sistema nervoso central (SNC) por via hematogênica (COX et al., 2000; OLSZEWSKI et al. 2004; REOLON et al., 2004; PEDROSO, 2008).

As fosfolipases e proteinases são consideradas fatores de virulência em leveduras em geral (BUCHANAN \& MURPHY, 1998; PESSOA et al, 2012) sendo relacionadas à invasão fúngica no sistema imunológico do hospedeiro, favorecendo a disseminação hematogênica e o acometimento das meninges (SANTANGELO et al, 1999; PESSOA et al, 2012). As fosfolipases em especial podem provocar desestabilização de membranas celulares, podendo causar lise e liberação de componentes lipídicos (GHANNOUM, 2000). 
1.4 Aspectos morfobioquímicos

Cryptocococcus spp. configura-se como levedura haploide, capsulada, ovalada, arredondada ou elipsoide medindo entre de 2 a $10 \mu \mathrm{m}$ de diâmetro (Figura 2), com a possibilidade de apresentar brotamento único ou múltiplo (KWON-CHUNG \& FELL, 1987; LACAZ et al., 2002; FAGANELLO et al,, 2006; NAYAK et al., 2010).

Em ágar Sabouraud as colônias são mucoides, brilhantes, com margem lisa e inteira, e com a cor entre o branco e o creme (FRIES et al., 2001). O ágar Níger ou ágar staib também pode ser utilizado, e quando há crescimento, as colônias são marrons, devido a produção de melanina, característica marcante do C. neoformans e C. gatti, (JACOBSON, 2000; PEDROSO et al., 2007; YAMAMURA, et al., 2013). Entretanto pode haver colônias não produtoras de melanina, chamadas cepas albinas (MANDAL et al., 2007).

Sobre os aspectos bioquímicos, C. neoformans e $C$. gattii não fermentam carboidratos, mas assimilam por mecanismo oxidativo a glicose, maltose, sacarose, galactose, trealose, melizitose, D-xilose, L-raminose, sorbitol, manitol, dulcitol, D-manitol, $\alpha$-metil-deglicosídeo, salicina, inositol e frutose. Também hidrolisam a uréia, por ação da urease e produzem fosfolipases e proteases (DE HOOG et al., 2000; CASALI et al., 2003; CAMPOS E BARONI, 2010).

A detecção da enzima urease é realizada utilizando-se meio uréia-ágar-base, no qual se observa a hidrólise da uréia e produção de amônio, aumentado o potencial hidrogeniônico $(\mathrm{pH})$ e fornecendo uma coloração rósea intensa (ARAÚJO JÚNIOR et al, 2015). 


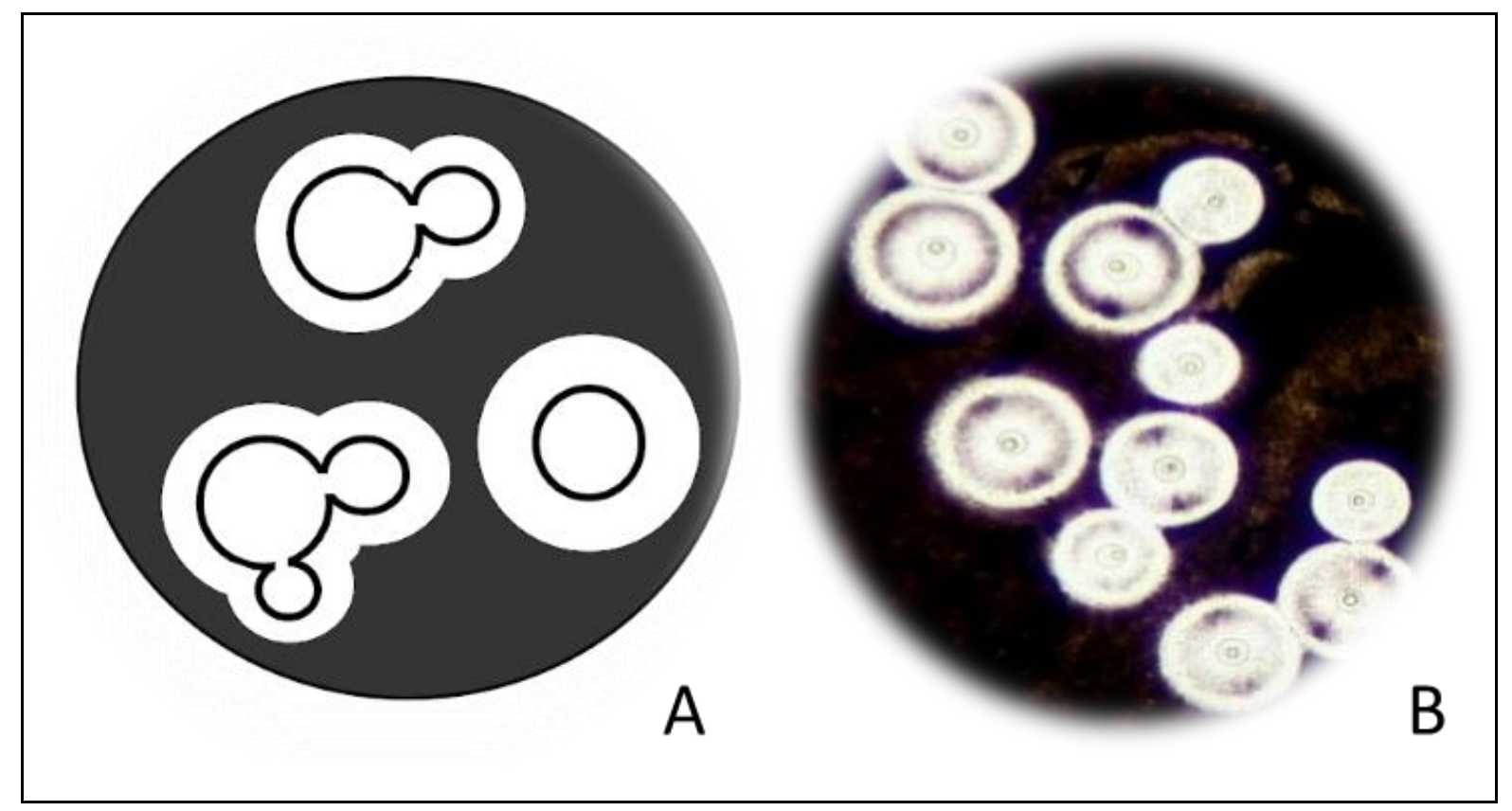

Figura 2 - Forma celulares de Cryptococcus spp.

Estrutura esquemática de Cryptococcus spp. em brotamento (A) e Cryptococcus spp. em brotamento visualizado em tinta nanquim (B)

Fonte: Adaptado de ZARAGOZA et al., 2006; LOURENÇO, 2015

\subsection{Criptococose}

A criptococose, também chamada de torulose, doença de Busse-Buschke e blastomicose européia, vem assumindo um papel relevante dentre as infecções fúngicas oportunistas por ser considerada uma das micoses mais comuns nos indivíduos imunodeprimidos (DARZÉ et al., 2000; LOCKHART et al., 2013). O impacto desta doença é extremamente significativo, apresentando elevada morbidade e mortalidade, sendo evidenciado em populações com acesso limitado aos serviços de saúde, acarretando cerca de 650.000 mortes por ano em todo mundo (PARK et al., 2009; HAYNES et al., 2011; TEODORO et al., 2013; PERFECT, 2013; MCCLELLAND et al., 2013; WANG et al., 2015; NYAZIKA et al., 2016).

O C. neoformans e C. gattii são as espécies que geralmente causam a criptococose, doença de impactante associação com pacientes portadores da Síndrome da Imunodeficiências Adquirida (Acquired Immune Deficiency Syndrome - AIDS), principalmente na África subsaariana e no sudeste da Ásia, áreas com alta incidência de infectados com o Vírus da Imunodeficiência Humana (Human Immunodeficiency Virus - HIV) (PARK et al., 2009; ASSOGBA et al., 2015; COGLIATI et al., 2016). Entretanto, atualmente a doença cada vez mais é encontrada em pacientes não infectados por HIV, como indivíduos com neoplasias 
hematológicas, transplantados de órgãos e com doenças autoimunes (BRATTON et al., 2012; SANCHINI et al., 2014; HENAO-MARTÍNEZ \& BECKHAM, 2015).

A criptococose é contraída pela inalação de partículas infecciosas, sejam esporos, estruturas fúngicas secas e/ou células de levedura em aerossol (ZAITZ et al., 2010; NASSER et al., 2011; LEV et al., 2015). Nos pulmões permanecem latentes até a ocorrência de alguma falha do sistema imunológico, havendo ativação e disseminação para o SNC, pele, ossos, articulações, olhos e coração (PAL \& DAVE, 2006; PANTOJA et al., 2006; COSTA et al., 2014).

Inicialmente ocorre infecção pulmonar, com possibilidade de cursar com quadro de pneumonia (NAYAK et al., 2010). Com a predileção do fungo pelo SNC, a meningoencefalite instala-se (TSENG et al., 2013; COLOMBO \& RODRIGUES, 2015), podendo ocorrer mais raramente trombose do seio venoso cerebral (SENADIM et al., 2016).

A presença do Cryptococcus spp. ainda pode culminar com a criptococemia e a produção de biofimes em dispositivos médicos, como cateteres, fístulas e próteses de válvulas cardíacas, devido sua disseminação hematogênica (MARTINEZ \& CASADEVALL, 2015; BENADUCCI et al., 2016).

Em 10 a $15 \%$ dos casos de criptococose sistêmica ocorrem lesões cutâneas, que raramente são oriundas de inoculação primária na pele. Em situações mais graves pode haver necrose cutânea (BIVANCO, et al., 2006; LIU, et al., 2015; JACKSON \& HERRING, 2015).

\subsection{Diagnóstico laboratorial}

O diagnóstico laboratorial da criptococose pode ser feito a partir de uma grande variedade de espécimes clínicos, como: líquor, urina, fragmentos de tecido, aspirados de lesões cutâneas, sangue, escarro e lavado bronco-alveolar (MEZZARI et al., 2013).

A identificação de fungos do gênero Cryptococcus pode ser feita por microscopia, cultura, provas bioquímicas manuais e automatizadas, sorologia, espectrometria de massa, técnicas moleculares e testes histológicos (MITCHELL \& PERFECT, 1995; AMARO, 2006; POSTERARO, et al., 2012).

A microscopia possibilita a visualização de leveduras encapsuladas (Figura 3) após preparação do espécime clínico com tinta da China, nigrosina, nanquim ou nankin, a qual permite a visualização nítida de um halo claro em torno da célula, que representa a cápsula não corada (NAMIQ et al., 2005; MENDES, 2009; XAVIER, et al., 2009). Além disso, pode 
ser utilizado o reagente branco de calcoflúor (CFW) para visualização do aspecto leveduriforme em microscópio de fluorescência (HARRINGTON \& HAGEAGE, 2003; GALANIS et al, 2009).

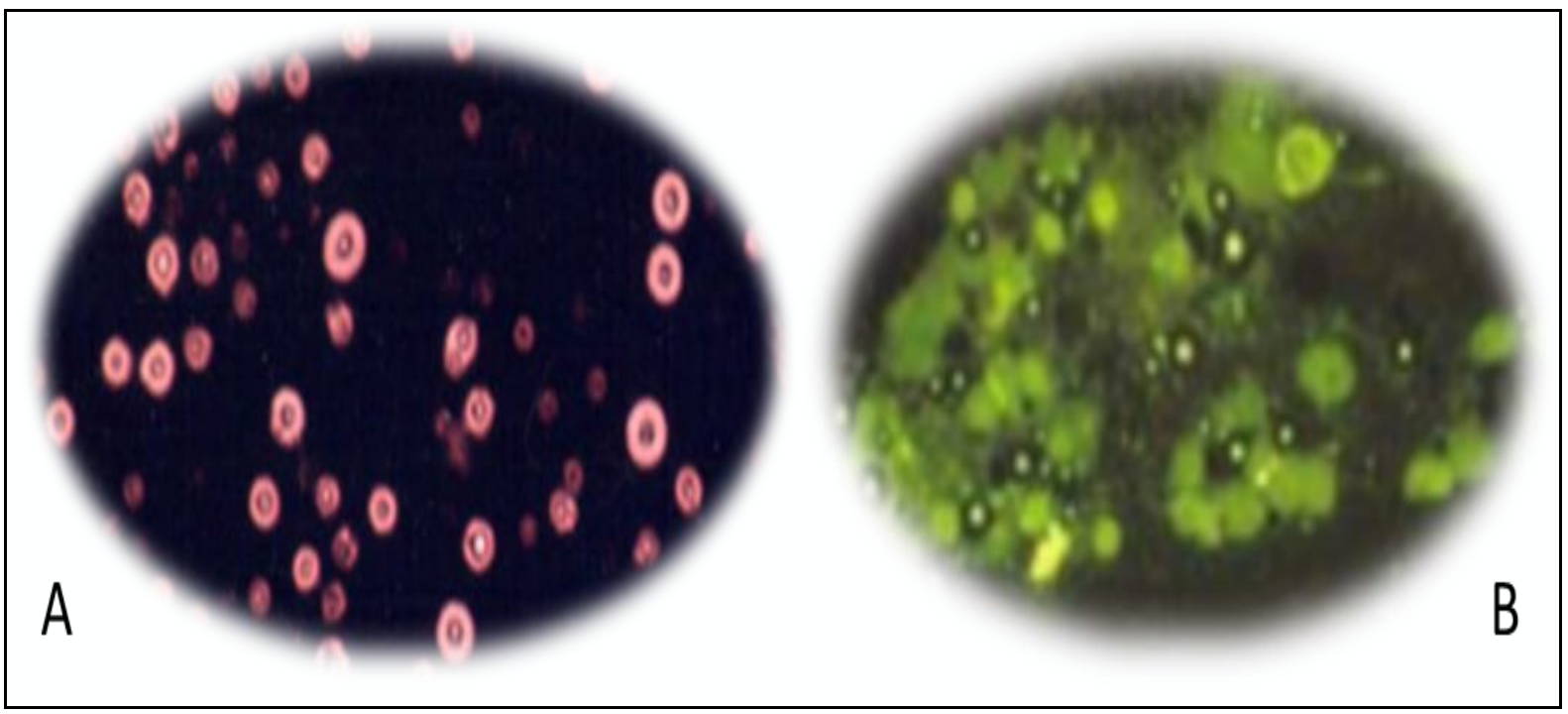

Figura 3 - Técnica de microscopia ótica para visualização de Cryptococcus spp.

Cryptococcus spp. visualizados em tinta da China (A) e Cryptococcus spp. visualizados em fluorescência após preparação com CFW (B)

Fonte: Adaptado de HARRINGTON \& HAGEAGE, 2003; NASSER et al., 2011

O isolamento de Cryptococcus spp.. pode ser feito em meios de cultura como ágar Sabouraud. Além disso é utilizado o ágar Níger para a caracterização da produção de melanina e ágar à base de L-canavanina, glicina e azul de bromotimol (CGB), que apresenta coloração diferente utilizada na diferenciação entre as espécies $C$. neoformans e $C$. gattii (GALANIS, et al, 2009; KLEIN et al., 2009; PEREIRA \& BARROS, 2012; MORA et al., 2015).

As colônias em ágar Sabouraud crescem com aspecto superficial brilhante, liso, com consistência cremosa a mucoide, coloração branca a bege. No ágar Níger, as colônias apresentam coloração marrom claro a marrom escuro (Figura 4), devido a produção de melanina (SANTOS et al., 2009; FARIA et al., 2010). 


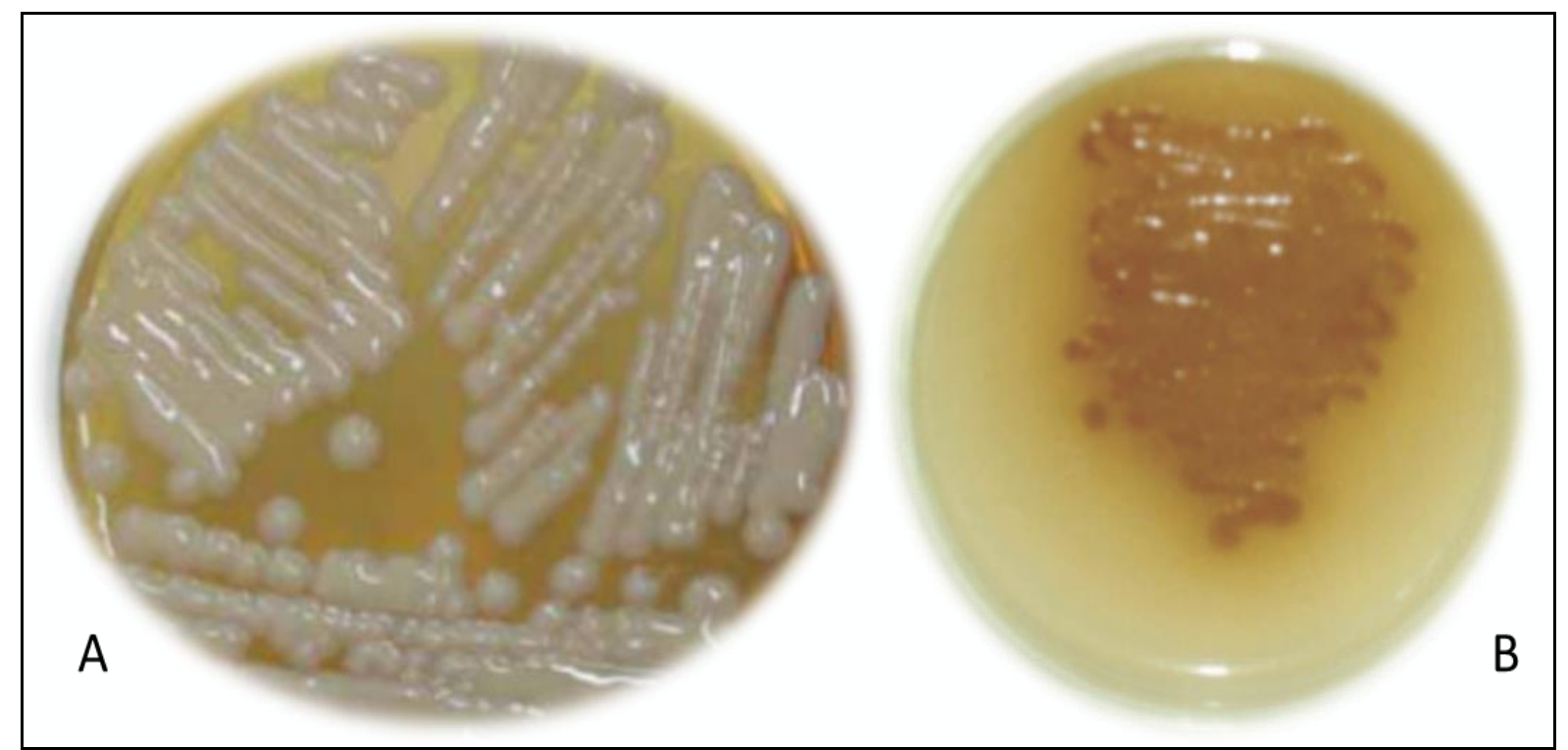

Figura 4 - Colônias de Cryptococcus spp. em meios de cultivo

Em ágar Sabouraud (A) e colônias de Cryptococcus neoformans em ágar Níger (B)

Fonte: Adaptado de GOMES et al., 2010; NASSER et al, 2011

No ágar CGB (Figura 5), quando há crescimento significa que as colônias são canavanina resistentes e capazes de utilizar a glicina como uma única fonte de carbono, provocando a cor azul, o que é indicativo de C. gattii. Quanto ao C. neoformans, este é sensível à canavanina e não utiliza a glicina como uma única fonte de carbono, não havendo crescimento e alteração de coloração (BYRNES et al., 2009b).

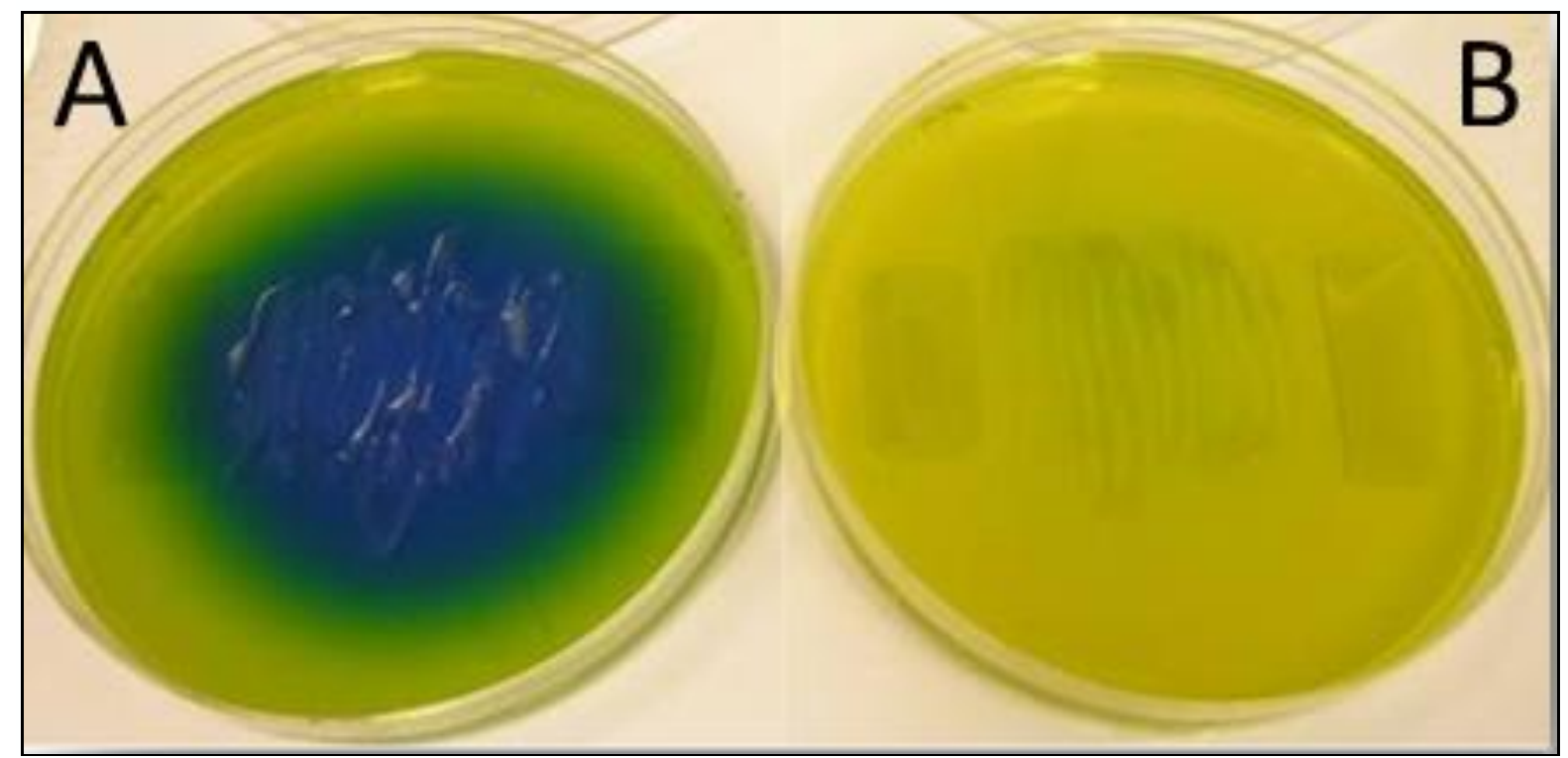

Figura 5 - Crescimento de Criptococcus spp. em ágar CGB

C. gattii (A) e C. neoformans (B) em ágar CGB

Fonte: Adaptado de KLEIN et al., 2009

As provas bioquímicas utilizadas em rotina laboratorial consistem na realização do teste manual da urease (Figura 6) ou a partir de testes automatizados, que podem analisar 
simultaneamente uma série de compostos, inclusive a urease, como: glicose, L-sorbose, galactose, D-ribose, D-xylose, L-arabinose, D-arabinose, L-ramnose, salicina, melibiose, sacarose, alfa-metila-D-glucósido, o inositol, a maltose, trealose, celobiose, lactose, rafinose, D-Glucitol, ribitol, eritritol, glicerol, melezitose, D-manitol, galactitol, D-L-ácido láctico e ácido succínico (ST GERMAIN \& BEAUCHESNE, 1991; SOUZA et al., 2001; MASSONET et al., 2004; MELHEM et al., 2013).

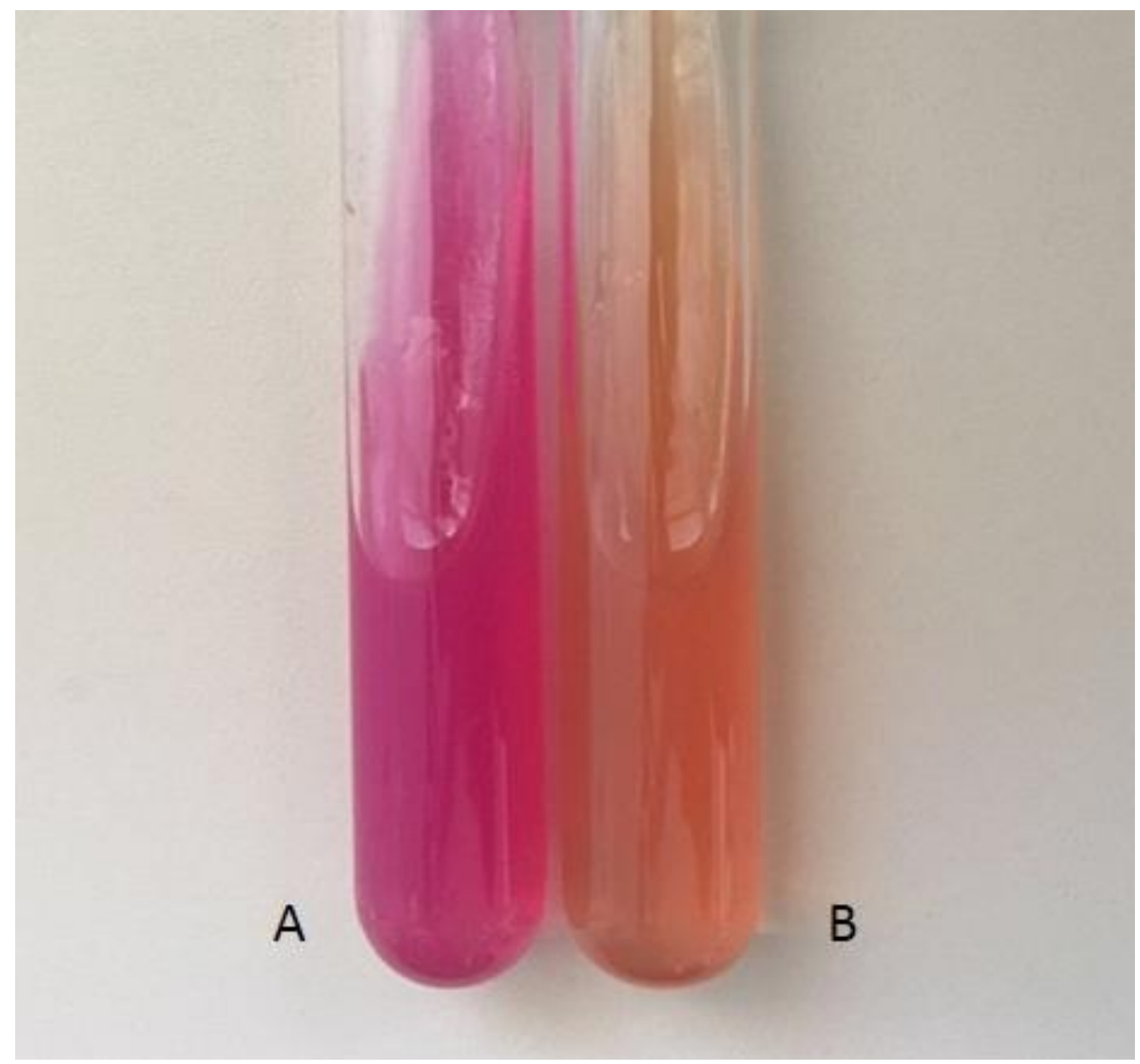

Figura 6 - Identificação bioquímica de Cryptococcus spp. em meio ureia-ágar-base No tubo A há produção de urease (reação positiva) e no tubo B não há produção (reação negativa)

Ainda é possível a realização de testes sorológicos, já que, durante a infecção por Cryptococcus spp., há a presença de antígenos capsulares polissacarídicos solúveis em fluidos corporais, como soro e Líquido Cefalorraquidiano (LCR), e podem ser detectados com a utilização de anti-soro específico em técnicas distintas como aglutinação em látex, Enzyme- 
linked Immunosorbent Assay (ELISA), imunodifusão radial e imunocromatografia (QUEIROZ et al., 2008; SEVERO et al., 2009).

Outra metodologia empregada na identificação é a espectrometria de massa do tipo Matrix-assisted laser desorption/ionization-time of flight mass spectrometry (MALDI-TOF), uma importante tecnologia, que vem revolucionando a prática da microbiologia como um todo (MARTINY et al., 2012), a partir da análise dos padrões de proteínas. As colônias isoladas e puras de Cryptococcus spp. são adicionados a uma matriz polimérica formando uma mistura, que é aplicada a um suporte. Este é irradiado com laser, havendo ionização e condução dos íons para o tubo do espectrômetro de massa, com posterior cálculo do tempo de vôo e separação a partir da carga e massa, formando espectros de proteínas características para cada micro-organismo (MCTAGGART et al., 2011; DE CAROLIS et al., 2014).

Os métodos moleculares representam potenciais ferramentas de diagnóstico, por apresentarem alta especificidade, no entanto, o uso destes métodos na rotina clínica laboratorial é limitado, devido à falta de padronização, difícil validação e expertise elevada exigida por parte dos profissionais envolvidos (ARVANITIS et al., 2014).

Vários procedimentos têm sido propostos para detectar e diferenciar espécies de Cryptococcus, incluíndo métodos de hibridação de ácidos nucleicos (SAMBROOK et al. 1989; SPITZER \& SPITZER, 1992) e técnicas baseadas na reação em cadeia da polimerase (PCR), como: PCR multiplex que se fundamenta no uso de primers específicos para a amplificação de regiões conservadas; PCR nested que utiliza pares de primers para amplificação do DNA (NEPPELENBROEK et al., 2014); PCR em tempo real (qPCR), que requer uma única corrida sem a necessidade de gel de ágarose para a análise, utilizando-se a amostra primária, minimizando-se as chances de contaminação (VERON et al., 2009); RFLP que baseia-se na caracterização de sítios de restrições (PINCUS et al., 2007); AFLP, que consiste em uma amplificação seletiva a partir de fragmentos de restrição do material genômico e MLST, que é uma tipagem de sequência multilocus (BOEKHOUT et al., 2001; LATOUCHE et al., 2003).

Outros exames a serem realizados em menor escala são os histopatológicos para visualização do micro-organismo, nos quais, os cortes histológicos podem ser corados por hematoxilina-eosina, mucicarmim de Meyer, ácido periódico Schiff (PAS), método de Gomori-Grocott e Fontana-Masson (LAZERA et al., 2004; PEDROSO \& CANDIDO, 2006). 


\subsection{Tratamento}

No tratamento da criptococose, a escolha do antifúngico está relacionada ao sítio de infecção e as características imunológicas do paciente (SEVERO et al., 2011). Os agentes antifúngicos disponíveis para o tratamento, correspondem a anfotericina $\mathrm{B}$ e sua diferentes formulções (poliênicos); fluconazol (triazólico) e 5-fluorocitosina ou flucitosina (análogos de pirimidina) (ZAITZ et al., 2010; MCCARTY \& PAPPAS, 2015).

Em função de suas toxicidades aguda e crônica existentes e na tentativa de melhorar sua eficácia terapêutica, diferentes formulações de anfotericina B vem sendo desenvolvidas e estão atualmente disponíveis como a anfotecina B liposomal ou lipossômica, complexo lipídico de anfotericina B e dispersão coloidal de anfotericina B (DORA \& SOUZA, 2005; GOVENDER et al., 2013).

Este agente antifúngico interage de forma específica com o ergosterol, constituinte da parede celular fúngica, e leva à formação de poros através das membranas lipídicas (FILIPPIN \& SOUZA, 2006), os poros formados danificam a membrana e alteram a permeabilidade celular, promovendo o extravasamento de componentes citoplasmáticos e posteriormente a morte celular (BAGINSKI \& CZUB, 2009).

Entretanto, formas de resistências a este antifúngico sugerem que as possíveis causas de resistência à anfotericina $\mathrm{B}$ podem estar relacionadas à ausência total de ergosterol na membrana fúngica e a presença de estruturas diferentes do ergosterol, que impossibilitam a ligação com os poliênicos (MORACE et al., 2014).

Os triazólicos apresentam atividade fungicida ou fungistática baseada na inibição da esterol-14- $\alpha$-desmetilase, prejudicando a síntese do ergosterol na membrana citoplasmática e levando ao acúmulo de 14- $\alpha$-metilesteróis, que não possuem a mesma forma e propriedades físicas que o ergosterol. Com isso ocorre a formação de uma membrana alterada, que não desempenha as funções exigidas para o desenvolvimento do fungo (BERGOLD \& GEORGIADIS, 2004). Os triazólicos apresentam a vantagem de causar menos reações adversas do que a anfotericina $\mathrm{B}$, entretanto possuem menor potência. Contudo, a sua utilização excessiva ocasionou o aparecimento de formas de resistência em espécies até então suscetíveis (SANTOS, et al., 2014). Essas formas de resistência podem ser explicadas por mecanismos de indução de bombas de efluxo, que levam à diminuição da concentração da droga antifúngica no alvo terapêutico (SANGUINETTI et al., 2015); de inibição e/ou superexpressão do gene ERG11, reduzindo a afinidade entre os azólicos e os sítios 
enzimáticos específicos (MORACE et al., 2014); e de mutação do gene ERG3, que impede a conversão do 14- $\alpha$-metil-3,6-diol para 14- $\alpha$-metilfecosterol com a substituição do ergosterol por fecosterol, bloqueando a ação do antifúngico na membrana (CARRILLO-MUÑOZ et al., 2006).

A flucitosina ou 5-fluorcitosina (5-FC) é uma alternativa terapêutica que promove efeitos fungistáticos e fungicidas sobre diversos gêneros, como Cryptococcus, Candida e Aspergillus. A flucitosina é uma pirimidina que após sua administração transforma-se, dentro da célula fúngica, em 5-fluoruracil e depois em 5-fluordesoxiuridina. Esse último comporta-se como um antimetabólito que interfere na biossíntese normal dos ácidos nucléicos e nucleotídeos fundamentais para o desenvolvimento do fungo. Tal fármaco é absorvido por via digestiva, distribuindo-se e atigindo o SNC e o LCR, (GHANNOUM \& RICE, 1999; MORACE et al., 2014), podendo ser usado de maneira sinérgica com anfotericina B, para pacientes com infecções fúngicas sistêmicas (FLEVARI et al., 2013), entretanto deve se levar em consideração seu efeito mielotóxico.

Os mecanismos de resistência para 5-FC baseiam-se nas múltiplas enzimas intracelulares requeridas para a sua ação como a mutação ou perda da atividade da permease codificada pelo gene $F C y 2$; modificação na enzima citosina deaminase codificada pelo gene FCyl e alteração na enzima UMP-pirofosforilase, codificada pelo gene FURl (CHAPELAND-LECLERC et al., 2005).

Contudo, a aplicação de metodologias que permitam a determinação das diversidades genômicas das espécies de Cryptococcus spp. e a investigaçãode mecanismos de virulência associados a estas espécies tem aumentado, com propósito de identificar novos alvos terapêuticos no combate da criptococose (BAHN \& JUNG, 2013).

A partir dessas informações percebe-se que o número de opções terapêuticas disponíveis é bastante limitado frente a gravidade e relevância da criptococose para a saúde pública. Soma-se a isso os efeitos colaterais associados a anfotericina-B e 5-flurocitosina e o aparecimento de resistência clínica ao uso de triazólicos ou com Concentração de Inibição Mínima (CIM) elevada, que dificultam cada vez mais as possibilidades de tratamento (FRIESE et al., 2001; ESPINEL-INGROFF et al., 2012a).

As falhas no tratamento também podem estar associadas a atrasos e erros no diagnóstico, assim como a falta de antifúngicos nas unidades hospitalares (BICANIC et al., 2007; DROMER et al., 2008; NUCCI \& PERFECT, 2008). 
Diante destas circunstâncias, estratégias farmacológicas vêm sendo utilizadas, representadas pela produção de novas formulações de antifúngicos, combinações terapêuticas entre os antifúngicos disponíveis e também terapias alternativas usando princípios ativos obtidos de fontes naturais, materiais sintéticos e materiais poliméricos (SPAMPINATO \& LEONARDI, 2013).

\subsection{Eugenia dysenterica (Mart.) DC}

Eugenia dysenterica (Mart.) DC é uma espécie vegetal pertencente à família Myrtaceae, utilizada como fonte de alimento e para fins medicinais. É uma arvore frutífera que está distribuída em toda a extensão do cerrado, incluindo várias unidades federativas brasileiras, predominando na Bahia, Distrito Federal, Goiás, Maranhão, Mato Grosso, Mato Grosso do Sul, Minas Gerais, Pará, Piauí, São Paulo e Tocantins (LORENZI et al., 2002; BRITO et al., 2003; MAZUTI SILVA et al., 2015).

Stenocalyx dysenterica, Stenocalyx dysentericus (Mart. Ex DC.) Berg e Myrtus dysenterica Mart são consideradas sinonímias botânicas (ALMEIDA et al., 1998). Já cagaita e cagaiteira são nomes populares que fazem referência ao efeito laxativo vinculado ao seu fruto (OLIVEIRA et al., 2012).

Visualmente, sua árvore quando adulta pode chegar a 8 metros de altura, 15 metros de amplitude e uma copa de 8 metros. A copa é alongada e densa, com ramos quadrangulares e glabros. Os botões, pedicelos, ramos jovens e folhas são dotados de diminutos pelos (MARTINOTTO et al., 2008).

As flores são brancas (Figura 7- A), odorizadas, solitárias, tretâmeras ou pentâmeras, dialipétalas e dialisépalas, elípticas; com cerca de $2 \mathrm{~cm}$ de diâmetro; possui muitos estames, apresentando estilite filiforme e estigma simples (PINA, 2008; FARIA JÚNIOR, 2010).

As folhas são descritas como membranáceas, de tamanho estimado entre 3 a $14 \mathrm{~cm}$ de comprimento e cerca de 1 a $8 \mathrm{~cm}$ de largura, aromáticas, simples, oposta-cruzadas, ovadaelípticas e elípticas a oblongo-elípticas (SILVA et al., 2001).

Os frutos são de coloração verde quando jovens e amarelo quando maduros (Figura 7 B). Apresentam casca fina e são considerados frutos do tipo baga, de formato globoso e levemente achatado. São suculentos, carnosos, brilhantes, com cerca de $90 \%$ de água e de sabor acidificado e ímpar (PROENÇA \& GIBBS, 1994; CAMILO et al., 2014). 


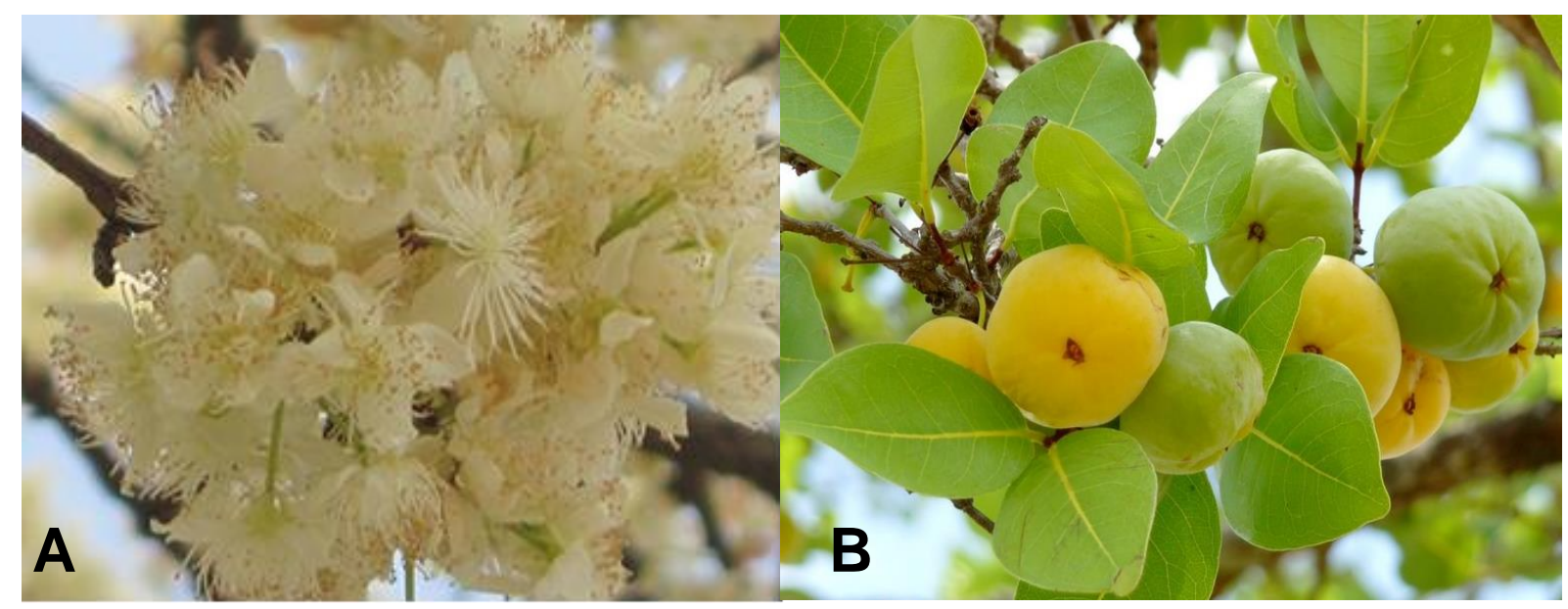

Figura 7. Flores (A) e frutos (B) de Eugenia dysenterica Fonte: Adaptado de DUBOC \& GUERRINI, 2007

Em relação aos constituintes químicos percebe-se uma grande variedade, nos quais destacam-se taninos, flavonoides, terpenos e saponinas no extrato etanólico de folhas de cagaita (CECÍLIO et al., 2012). Em frutos foram encontrados ácido gálico, compostos fenólicos (catequinas e procianidinas) e carotenóides. Além destes, em óleos essenciais foram encontradas substâncias como: $\beta$-cariofileno, $\alpha$-humuleno, limoneno, $\alpha$-tujeno, $\alpha$-terpineol e óxido de $\beta$-cariofileno, $\alpha$-pineno, (Z)- $\beta$ ocimeno, (E)- $\beta$-ocimeno, e $\gamma$-cadineno (COSTA et al., 2000; DUARTE et al., 2010; SOUSA et al., 2012).

As atividades biológicas dos extratos de folhas de E. dysenterica apresentam propriedades antidiarréica (LIMA et al., 2011), antioxidante, gastroprotetora associada à inibição da produção de ácido clorídrico (PRADO et al., 2014), atividades antiviral (CECÍLIO et al., 2012), inibitória em relação $\alpha$-amilase e $\alpha$-glucosidase (SOUSA et al., 2012) e antifúngica (COSTA et al., 2000).

A atividade antifúngica evidenciada por Costa e cols. (2000) demostrou que óleos essenciais de E. dysenterica foram ativos contra oito cepas de Candida albicans, 35 cepas de C. neoformans e duas de $C$. gattii, na qual, o resultado mais significativo foi contra as cepas de Cryptococcus. Em estudo recente do nosso grupo, Correia e cols. (2016) também mostraram alto efeito inibitório de extrato aquoso de folhas $E$. dysenterica contra espécies de Candida não albicans, entre elas C. parapsilosis, C. guillermondii, C. krusei, C. tropicalis e C. famata. Tendo em vista o potencial antifúngico de E. dysenterica contra microorganismos fúngicos e diante das poucas opções terapêuticas convencionais e dos seus elevados grau de toxicidade, e o fato de nem sempre haver resolutividade nos tratamentos de criptococose, a procura por produtos oriundos de plantas medicinais apresenta-se como relevante realidade, que deve ser melhor estudada. 


\section{OBJETIVOS}

\subsection{Objetivo Geral}

Identificar isolados clínicos de Cryptococcus spp, demonstrando as características fenotípicas e genotípicas das diferentes espécies e avaliar o perfil de susceptibilidade aos agentes antifúngicos convencionais e ao extrato aquoso bruto de Eugenia dysenterica.

\subsection{Objetivos Específicos}

Identificar espécies de Cryptococcus spp., por métodos clássicos morfológicos e bioquímicos.

Confirmar a identificação das espécies de Cryptococcus spp através do gene URA5 utilizando método molecular PCR-RFLP.

Verificar a acurácia da técnica de espectrometria de massas Matrix Assisted Laser Desorption Ionization Time-of-flight (MALDI-TOF) para identificação das espécies de Cryptococcus spp.

Determinar o perfil de susceptibilidade de Cryptococcus spp. frente à antifúngicos comerciais.

Testar extrato bruto de Eugenia dysenterica contra Cryptococcus spp. por método de Concentração Inibitória Mínima (CIM). 


\section{MATERIAL E MÉTODOS}

\subsection{Caracterização microbiológica}

\subsubsection{Amostras}

Foram analisados 20 isolados de Cryptococcus spp. provenientes de cultivo de líquido cefalorraquidiano (LCR) $(n=15)$, sangue $(n=2)$, lavado broncoalveolar $(n=1)$, fragmento de pele $(n=1)$ e aspirado traqueal $(n=1)$, oriundos de pacientes com suspeita de micose sistêmica, atendidos nas unidades de saúde da rede pública do Distrito Federal. O processamento das amostras biológicas foi realizado pelo Laboratório de Micologia do Núcleo de Parasitologia e Micologia (NPM) do Laboratório Central de Saúde Pública do Distrito Federal (LACEN-DF). Este estudo foi aprovado pelo parecer $n^{\circ}$ 1.385.224 do Comitê de Ética em Pesquisa da Faculdade de Ciências da Saúde da Universidade de Brasília (CEP/FS-UnB) (ANEXO 1).

Tabela 2 - Isolados clínicos de pacientes com suspeita de micoses sistêmicas

\begin{tabular}{lcc}
\hline \multicolumn{1}{c}{ Amostras biológicas } & Número & \% \\
\hline Líquido cefalorraquidiano & 15 & 75 \\
\hline Sangue & 2 & 10 \\
\hline Lavado broncoalveolar & 1 & 5 \\
\hline Fragmento de pele & 1 & 5 \\
\hline Aspirado traqueal & 1 & 5 \\
\hline Total & $\mathbf{2 0}$ & $\mathbf{1 0 0}$ \\
\hline
\end{tabular}

\subsubsection{Exame direto}

A presença de Cryptococcus spp. nas amostras de LCR foi detectada por microscopia óptica com aumento de $400 \mathrm{X}$, por meio de montagem em lâmina com tinta nanquim, que permitiu a visualização da cápsula, devido a exclusão do corante, formando área clara ao redor da célula leveduriforme oriundas de LCR. Para as outras amostras biológicas, sangue, lavado broncoalveolar, fragmento de pele e aspirado traqueal, as células leveduriformes foram detectadas utilizando solução de hidróxido de potássio $(\mathrm{KOH})$ a $20 \%$, como reagente digestor e clarificante (ZAITZ et al., 2010; LARONE, 1995). 


\subsubsection{Isolamento fúngico}

A obtenção dos isolados foi feita a partir de cultivos das amostras biológicas a $25{ }^{\circ} \mathrm{C}$ $\left( \pm 2{ }^{\circ} \mathrm{C}\right)$ em tubos de ágar Sabouraud dextrose com cloranfenicol (HiMedia, Mumbai, Índia), ágar Níger (HiMedia, Mumbai, Índia) e ágar Littman (HiMedia, Mumbai, Índia) e a $37^{\circ} \mathrm{C}$ em ágar Fava Neto. O crescimento leveduriforme foi observado em até 72 horas (LARONE, 1995).

\subsubsection{Conservação dos isolados clínicos}

Os isolados foram conservados em criotubos de $2,0 \mathrm{~mL}$, em solução aquosa de glicerina a $10 \%$ e conservados à temperatura de $20{ }^{\circ} \mathrm{C}$ negativos, possibilitando posterior recuperação e processamento dos microrganismos fúngicos (NEUFELD, 1999).

\subsubsection{Testes bioquímicos manuais}

Para a realização dos testes bioquímicos, os isolados congelados foram subcultivados em tubos de ágar Sabouraud dextrose com cloranfenicol (HiMedia, Mumbai, Índia) a $25^{\circ} \mathrm{C}$ por 24 a 48 horas de incubação, até que ocorresse crescimento adequado (LARONE, 1995). Colônias frescas e puras obtidas foram inoculadas em tubos de ágar Níger, ágar uréia e placas de ágar CGB e incubadas novamente a $25{ }^{\circ} \mathrm{C}$ por 24 a 48 horas, a fim de detectar no ágar niger a formação de colônias escurecidas, indicativas de produção de melanina, em ágar uréia a produção de urease e ágar CGB a assimilação de glicina (KLEIN et al, 2009).

Tabela 3 - Teste de identificação bioquímica para Cryptococcus spp.

\begin{tabular}{lll}
\hline Testes bioquímicos & Produto de reação & Indicador de coloração \\
\hline Ágar Níger & Produção de melanina & $\begin{array}{l}\text { Colônias escurecidas (reação positiva) } \\
\text { Colônias cremes (reação negativa) }\end{array}$ \\
\hline Ágar uréia & Produção de urease & $\begin{array}{l}\text { Colônias róseas (reação positiva) } \\
\text { Colônias cremes (reação negativa) }\end{array}$ \\
\hline Ágar CGB & Assimilação de glicina & $\begin{array}{l}\text { Colônias azuis (reação positiva) } \\
\text { Colônias amarelas (reação negativa) }\end{array}$ \\
\hline
\end{tabular}




\subsubsection{Testes bioquímicos automatizados}

Foram utilizados cartões de identificação para leveduras do sistema VITEK® 2 Compact (BioMérieux ${ }^{\circledR}$, França) constituídos por 46 testes colorimétricos, que envolvem reações de assimilação de carboidratos (20), ácidos orgânicos (6) e nitrato (1); reações de oxidase (8), aril-amidase (9), fosfatase (1) e urease (1).

Para a preparação dos cartões de identificação foram realizados subcultivos, com os isolados, em tubos de ágar Sabouraud dextrose com cloranfenicol (HiMedia, Mumbai, Índia) a $25^{\circ} \mathrm{C}$ por 24 a 48 horas de incubação, até que ocorresse crescimento adequado (LARONE, 1995). Em seguida, colônias foram suspensas em solução salina estéril ( $\mathrm{NaCl}$ aquoso de 0,45 a $0,50 \%, \mathrm{pH} 4,5$ a 7,0) em tubos $(75 \mathrm{X} 12 \mathrm{~mm})$ de poliestireno transparente, até a obtenção de solução com densidade equivalente a 2,0 da escala de Mc Farland. Para isto foi utilizado o calibrador VITEK® 2 DensiChek (BioMérieux®, França), medidor de turbidez.

Os tubos e os cartões foram dispostos em suportes de amostras (racks) e estas inseridas na plataforma VITEK® 2 Compact (BioMérieux®, França) com a finalidade de distribuir a suspensão do inóculo fúngico entre os poços dos cartões, que foram selados e incubados a $35,5^{\circ} \mathrm{C}$ por até 18 horas, para leituras ópticas feita automaticamente a cada 15 min. A partir destas leituras, perfis de identificação foram estabelecidos e interpretados de acordo com um algoritmo específico, proporcionando identificação do organismo desconhecido e classificando as identificações finais como: "excelente", "muito bom", "bom", "aceitável" ou "baixa discriminação" (HATA et al., 2007).

\subsubsection{Método molecular PCR-RFLP}

A técnica de PCR-RFLP foi realizada no Laboratório de Micologia do Instituto de Higiene e Medicina Tropical (IHMT) da Universidade Nova de Lisboa (UNL), Portugal.

\subsubsection{Extração do DNA do Cryptococcus spp.}

Foram realizados subcultivos dos isolados de Cryptococcus spp. em tubos de ágar Sabouraud dextrose com cloranfenicol (HiMedia, Mumbai, Índia) a $25{ }^{\circ} \mathrm{C}$ por 24 a 48 horas de incubação, até que ocorresse crescimento adequado (LARONE, 1995). Em seguida as colônias de leveduras foram transferidas para um microtubo de 1,5 mL contendo um volume 
de $200 \mu \mathrm{L}$ de esferas de vidro (0,4-0,6 mm de diâmetro) e $500 \mu \mathrm{L}$ de Tampão de Lise (Tris 50 mM, NaCl 250 mM, EDTA 50 mM, SDS 0,3 \% (p/v), pH 8). Em seguida, esse microtubo foi agitado em vórtex durante 3 minutos continuamente, até a formação de uma suspensão celular densa.

No passo seguinte, o microtubo foi colocado em banho-maria a $65^{\circ} \mathrm{C}$ durante $1 \mathrm{~h}$, e posteriormente a suspensão fúngica foi novamente agitada no vórtex durante 3 min e centrifugada por 10 min a $11000 \mathrm{~g}$. Após a centrifugação, o sobrenadante que contém o DNA foi separado para um novo microtubo, e congelado a $-20{ }^{\circ} \mathrm{C}$ até a realização da técnica de PCR-RFLP.

\subsubsection{Método de PCR-RFLP}

Para a realização da técnica de PCR-RFLP inicialmente foi realizada uma diluição de 1:750 em tampão Tris-HCl do DNA fúngico extraído, e para padronizar a concentração de DNA foi realizada uma purificação, seguida de quantificação em espectrofotômetro NANODROP ND-100 (Thermoscientific, Walthan, EUA) e um ajuste para a concentração 50 ng do DNA desejada. A qualidade do DNA extraído foi avaliada através de eletroforese em gel de agarose a $1 \%$ corado com brometo de etídio $(0,5 \mu \mathrm{g} / \mathrm{mL})$.

O gene URA5 foi amplificado em $50 \mu \mathrm{L}$, contendo: 50 ng DNA, tampão PCR 1x (10mM Tris- $\mathrm{HCl} \mathrm{pH} 8.3,50 \mathrm{mM} \mathrm{KCl}, 1,5 \mathrm{mM} \mathrm{MgCl}_{2}$ ), 0,2 mM de cada dATP, dCTP e dTTP, 3mM MgAc, 1,5 U Taq DNA polimerase, e $50 \mathrm{ng}$ de cada primer: ura5 fold (5' ATGTCCTCCCAAGCCTCGACTCCG3') e ura5 reverse (5' TTAAGACCTCTGAACACCGTACTC3').

A ciclagem foi realizada usando termociclador com: 1 ciclo de $94{ }^{\circ} \mathrm{C}$ por $3 \mathrm{~min}, 35$ ciclos de $94{ }^{\circ} \mathrm{C}$ por $45 \mathrm{~s}, 61{ }^{\circ} \mathrm{C}$ por $1 \mathrm{~min}$, e $72{ }^{\circ} \mathrm{C}$ por $10 \mathrm{~min}$, seguido de um ciclo de $72{ }^{\circ} \mathrm{C}$ por 10 min. Os produtos da amplificação no PCR foram digeridos com Saup81 e that por 3h ou overnight e separados em gel de agarose $3 \%$ por eletroforese empregando $100 \mathrm{v}$ por $5 \mathrm{~h}$.

Para otimizar a técnica de PCR-RFLP quanto à tipificação de isolados de Cryptococcus spp., foram empregadas cepas de referência correspondentes aos 8 tipos moleculares descritos na tabela 4. 
Tabela 4 - Cepas de referência do complexo Cryptococcus spp.

\begin{tabular}{|c|c|c|}
\hline Espécie referência & Espécie identificada & Origem \\
\hline WM148 (=CBS 10085) & $\begin{array}{l}\text { Cryptococcus neoformans } \\
\text { (tipo molecular VNI) }\end{array}$ & LCR, Austrália (sorotipo A) \\
\hline WM626 (=CBS 10084) & $\begin{array}{l}\text { Cryptococcus neoformans } \\
\text { (tipo molecular VNII) }\end{array}$ & LCR, Austrália (sorotipo A) \\
\hline WM629 (=CBS 10079) & $\begin{array}{l}\text { Cryptococcus neoformans } \\
\text { (tipo molecular VNIV) }\end{array}$ & Sangue, Austrália (sorotipo D) \\
\hline WM628 (=CBS 10080) & $\begin{array}{l}\text { Cryptococcus neoformans } \\
\text { (híbrido - tipo molecular VNIII) }\end{array}$ & LCR, Austrália (sorotipo AD) \\
\hline WM179 (=CBS 10078) & $\begin{array}{l}\text { Cryptococcus gattii } \\
\text { (tipo molecular VGI) }\end{array}$ & LCR, Austrália (sorotipo B) \\
\hline WM178 (=CBS 10082) & $\begin{array}{l}\text { Cryptococcus gattii } \\
\text { (tipo molecular VGII) }\end{array}$ & Pulmão, Austrália (sorotipo B) \\
\hline WM161 (=CBS 10081) & $\begin{array}{l}\text { Cryptococcus gattii } \\
\text { (tipo molecular VGIII) }\end{array}$ & Eucalyptus debris, Estados Unidos (sorotipo B) \\
\hline WM161 (=CBS 10101) & $\begin{array}{l}\text { Cryptococcus gattii } \\
\text { (tipo molecular VGIV) }\end{array}$ & Guepardo, África do Sul (sorotipo C) \\
\hline $\begin{array}{l}\text { CN137 (=PYCC } 3957 \\
\text { CBS 132) }\end{array}$ & Cryptococcus neoformans & Suco de fruta fermentado (híbrido AD) \\
\hline
\end{tabular}

Fonte: Laboratório de Micologia, IHMT

\subsubsection{Espectrometria de massa}

As espécies de Cryptococcus foram analisadas por espectrometria de massa na estação de preparação Vitek MS (BioMérieux®, França). Para isto, colônias dos isolados de Cryptococcus spp., subcultivados em tubo de ágar Sabouraud dextrose com cloranfenicol (HiMedia, Mumbai, Índia) a $25^{\circ} \mathrm{C}$ por 24 a 48 horas de incubação, foram aplicadas em splots do suporte para inoculação/identificação (BioMérieux®, França) e, em seguida tratadas com $0,5 \mu \mathrm{L}$ de ácido fórmico (25\% [vol / vol] - BioMérieux®, França). Após secagem à temperatura ambiente, $1 \mu \mathrm{L}$ de matriz de ácido $\alpha$-ciano-4-hidroxicinâmico (3.1 \% [peso / vol]) - BioMérieux, França) foi adicionado e novamente sofreu processo de secagem à temperatura ambiente antes da análise por espectrometria de massa (KIM et al., 2014).

O suporte de inoculação/identificação foi inserido na estação de leitura e a identificação fúngica foi obtida por meio de espectros. Os espectros formados foram comparados com espectros padrões armazenados nos bancos de dados MYLA® (BioMérieux ${ }^{\circledR}$, França) e Spectral Archive and Microbial Identification System (SARAMIS) 
(Shimadzu®, Japão). Esta comparação é realizada por meio de sobreposição de picos, capazes de caracterizar espécie, gênero ou família dos micro-organismos, resultando em probabilidade relativa da identificação (KIM et al., 2014).

Foram considerados válidos o percentual de probabilidade de identificação igual ou maior de $85 \%$. Como controle positivo foi utilizado cepa de referência de Escherichia coli ATCC 8739 (KIM et al., 2014).

\subsection{Determinação do perfil de susceptibilidade de Cryptococcus spp.}

\subsubsection{Agentes antifúngicos}

Foram utilizados os cartões de sensibilidade fúngica AST-YS07 (BioMérieux®, França) no sistema VITEK ${ }^{\circledR} 2$ Compact (BioMérieux®, França), a fim de determinar as sensibilidades aos seguintes agentes antifúngicos: Anfotericina B (AB), Fluconazol (FLU) e Flucitosina (FCT).

\subsubsection{Preparo do inóculo fúngico}

A partir de subcultivos dos isolados fúngicos, em tubos de ágar Sabouraud dextrose com cloranfenicol (HiMedia, Mumbai, Índia) a $25{ }^{\circ} \mathrm{C}$ por 24 a 48 horas de incubação, foram preparados inóculos fúngicos. Para isto, colônias foram suspensas em 3,0 mL de solução salina estéril ( $\mathrm{NaCl}$ aquoso de 0,45 a $0,50 \%, \mathrm{pH} 4,5$ a 7,0) contidas em tubos (75 x $12 \mathrm{~mm}$ ) de poliestireno transparente, até obter uma suspensão equivalente a 2,0 da escala de Mc Farland. Para isto foi utilizado o calibrador VITEK® 2 DensiChek (BioMérieux®, França), medidor de turbidez.

\subsubsection{Leitura e interpretação dos resultados}

Os cartões foram carregados com as respectivas suspensões de leveduras que foram diluídas adequadamente pelo equipamento. Após o preenchimento, os cartões foram incubados, ocorrendo a leitura automaticamente. O tempo de incubação variou de 9,1 a 27,1 h (tempo médio de 18,1 h), com base na taxa de crescimento microbiano. Os resultados foram expressos como valores de Concentração Inibitória Mínima (CIM) em $\mu \mathrm{g} / \mathrm{mL}$. 
Os resultados de CIM obtidos no sistema VITEK $® 2$ Compact foram comparadas com os Epidemiologic Cutoff Value (ECV), pois até o momento, não há breakpoints estabelecidos para antifúngicos contra Cryptococcus spp. Os valores de breakpoints foram baseados a partir de dois estudos de Espinel-Ingroff e cols. (2012a e 2012b).

\subsection{Avaliação da atividade antifúngica do extrato aquoso de Eugenia dysenterica}

\subsubsection{Material botânico}

Para o teste de atividade antifúngica foi utilizado extrato aquoso das folhas de Eugenia dysenterica, pertecente a família Myrtaceae, obtido da região do Cerrado e entorno de Brasília, Distrito Federal. Esta espécie foi identificada e depositada em excicata, voucher 914 (UnB), pelos professores Christopher William Fagg e Suelí Maria Gomes, no Herbário da Universidade de Brasília.

\subsubsection{Extração botânica}

As folhas de E. dysenterica após secagem em temperatura ambiente, foram pulverizadas em moinho de facas e extraídas por infusão, utilizando $400 \mathrm{~g}$ do material botânico e 3L de água destilada. Após filtação, a parte líquida foi removida por liofilização (SOUZA, et al., 2012). Os extratos utilizados neste trabalho foram cedidos gentilmente pelo Grupo de Pesquisa, Desenvolvimento, Produção e Controle da Qualidade de Medicamentos e foram produzidos pelo Laboratório de Produtos Naturais (LPN) da Universidade de Brasília $(\mathrm{UnB})$.

\subsubsection{Concentração Inibitória Mínima}

\subsubsection{Preparação do meio de cultura}

Foi utizado RPMI-1640 suplementado com glutamina, vermelho de fenol, sem bicarbonato. Foi adicionado 3-( $N$-morpholimo) ácido propanosulfônico (MOPS) e ajustado em pH 7,0. A esterilização do meio foi realizada por filtração e sua conservação mantida em $4^{\circ} \mathrm{C}$. 


\subsubsection{Preparo do inóculo fúngico}

O inóculo fúngico foi obtido por meio de subcultivo dos isolados de Cryptococcus spp. em ágar Sabouraud dextrose com cloranfenicol (HiMedia, Mumbai, Índia) à $25^{\circ} \mathrm{C}( \pm 2$ ${ }^{\circ} \mathrm{C}$ ) por 24 a 48 horas. Para isto, foram suspensas colônias em 3,0 mL de solução salina estéril 0,45\%, contidas em tubos de ensaios, até obter uma suspensão equivalente a 0,5 da escala de McFarland. A leitura do inóculo fúngico foi realizada utilizando o medidor de turbidez VITEK® 2 DensiChek (BioMérieux®, França).

Após preparação desta suspensão padrão procedeu-se diluições de 1:50 seguida de uma diluição 1:20 ambas em caldo RPMI-1640.

Após as diluições, foi adicionado ao inóculo fúngico $15 \mu \mathrm{L}$ de solução aquosa de ressazurina estéril à $20 \mu \mathrm{g} / \mathrm{mL}$, a fim de revelar o crescimento fúngico por meio de mudança de coloração, de azul (ausência de crescimento fúngico) a rosa (presença de crescimento fúngico) (MANJUAN et al., 2007).

\subsubsection{Preparação da solução estoque}

A solução estoque do extrato de E. dysenterica e do controle positivo a fluconazol foram preparados em dimetilsulfóxido (DMSO) a $1 \%$ com concentração final de $100 \mathrm{mg} / \mathrm{mL}$ e $2 \mathrm{mg} / \mathrm{mL}$, respectivamente (MANJUAN et al., 2007).

\subsubsection{Preparação da placa}

Para o teste de microdiluição foram utilizadas placas de 96 poços. Inicialmente, foi adicionado $100 \mu \mathrm{L}$ do caldo RPMI 1640 em cada poço. Em seguida diluições seriadas de 1:2 foram realizadas com solução estoque do extrato aquoso iniciando com concentração de $50.000 \mu \mathrm{g} / \mathrm{mL}$ e concentração final de $24,41 \mu \mathrm{g} / \mathrm{mL}$. Diluições seriadas de 1:2 também foram realizadas para o controle positivo (fluconazol), cuja concentração inicial foi de $1000 \mu \mathrm{g} / \mathrm{mL}$ e final de $0,976 \mu \mathrm{g} / \mathrm{mL}$. Posteriormente $100 \mu \mathrm{L}$ do inóculo fúngico foi adicionado em cada poço. Controles de esterilidade e crescimento foram realizados, utilizando-se o caldo RPMI 1640 e caldo RPMI 1640 com microrganismos do gênero Cryptococcus, respectivamente. As placas foram incubadas a $37^{\circ} \mathrm{C}$ por 48 horas (MANJUAN et al., 2007). 


\subsubsection{Leitura e interpretação dos resultados}

A leitura foi realizada por visualização da mudança de coloração dos poços. Para este estudo, a CIM foi interpretada como a menor concentração que manteve sua coloração inicial (azul), indicando ausência de crescimento ou a primeira diluição que sofreu alteração de azul para sutilmente rosa, equivalente a inibição proeminente do crescimento (MANJUAN et al., 2007).

Em função da coloração escura do extrato de E. dysenterica, não foi possível a leitura da absorvância em leitoras de placas convencionais. Tal limitação foi suprimida com a realização de semeios em ágar Sabouraud de alíquotas provenientes dos poços da placa para verificação de crescimento fúngico. 


\section{RESULTADOS E DISCUSSÃO}

\subsection{Características microbiológicas dos isolados clínicos}

No exame direto (Tabela 5), utilizando tinta nanquim e $\mathrm{KOH}$ a $20 \%$, os isolados de Cryptococcus spp. foram caracterizados como estrututas celulares arrendondadas com ou sem brotamento. A utilização de tinta nanquim no líquido cefalorraquidiano permitiu também a observação de estrutura capsular, importante fator de virulência, inerente as espécies de Cryptococcus (Figura 8).

Tabela 5 - Características microscópicas das amostras biológicas por exame direto

\begin{tabular}{lcc}
\hline \multirow{2}{*}{ Amostras biológicas } & \multicolumn{2}{c}{ Características microscópicas } \\
\cline { 2 - 3 } Líquido cefalorraquidiano & $\begin{array}{c}\text { Células arrendodadas com ou sem } \\
\text { brotamento encapsuladas }\end{array}$ & KXame não realizado \\
\hline $\begin{array}{l}\text { Sangue } \\
\text { Lavado broncoalveolar }\end{array}$ & Exame não realizado & Células arrendodadas com ou sem \\
$\begin{array}{l}\text { Fragmento de pele } \\
\text { Aspirado traqueal }\end{array}$ & & brotamento \\
\hline
\end{tabular}

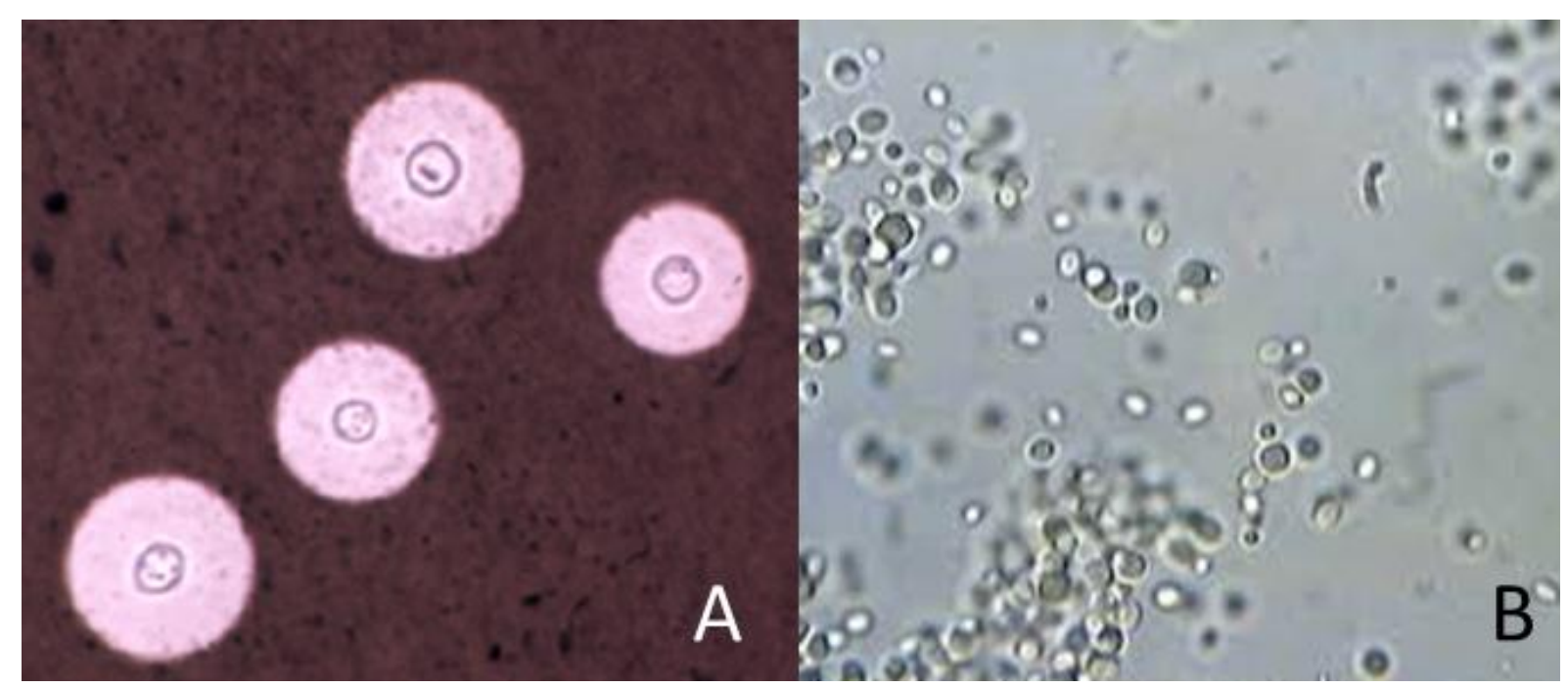

Figura 8 - Visualização microscópica de Cryptococcus spp.

Análises em Tinta naquim (A) e $\mathrm{KOH}$ (B)

$\mathrm{Na}$ identificação macroscópica, todos os isolados apresentaram colônias com características morfológicas de Cryptococcus spp., com aspecto mucóide, brilhante, úmido e com coloração inicialmente creme no ágar Sabouraud dextrose com cloranfenicol, ágar Littman e no ágar Fava Neto, e coloração enegrecida em ágar Níger.

Colônias enegrecidas no ágar Níger, foram demonstradas por todos os isolados $(\mathrm{n}=20)$. Esta característica de produzir melanina a partir da reação entre fenol oxidase, 
produzida pelo micro-organismo, com ácido cafeico presente no meio, é típica de espécies de Cryptococcus neoformans ou Cryptococcus gattii e permite a diferenciação destas espécies com outras espécies de Cryptococcus (KLEIN et al., 2009).

A produção de urease no meio ágar uréia também ocorreu em todos os isolados $(\mathrm{n}=20)$, corroborando com a caracterização das espécies do gênero Cryptococcus, uma vez que, outras espécies de levedura, como por exemplo espécies do gênero Trichosporon e algumas espécies do gênero Candida são urease negativa (KLEIN et al., 2009).

Embora os meios ágar Níger e ágar uréia auxiliam na caracterização do gênero Cryptococcus, estes não possibilitam a diferenciação entre as espécies de Cryptococcus. Neste caso, foi utilizado o ágar CGB, que é um efetivo meio de diferenciação entre as duas principais espécies de interesse clínico, C. neoformans e C. gattii.

No ágar CGB, 8 isolados assimilaram glicina, sendo caracterizado como Cryptococcus gattii e 12 isolados não assimilaram glicina e foram identificados como Cryptococcus neoformans.

Tabela 6 - Resultados dos testes bioquímicos manuais

\begin{tabular}{lcccc}
\hline Identificação & $\begin{array}{c}\text { Número de isolados } \\
\text { clínicos }\end{array}$ & $\begin{array}{c}\text { Produção de } \\
\text { melanina }\end{array}$ & $\begin{array}{c}\text { Produção de } \\
\text { urease }\end{array}$ & $\begin{array}{c}\text { Assimilação de } \\
\text { glicina }\end{array}$ \\
\cline { 3 - 5 } C.gattii & 8 & $8 / 8(100 \%)$ & $8 / 8(100 \%)$ & $8 / 8(100 \%)$ \\
C. neoformans & 12 & $12 / 12(100 \%)$ & $12 / 12(100 \%)$ & $0 / 12(0 \%)$ \\
\hline
\end{tabular}




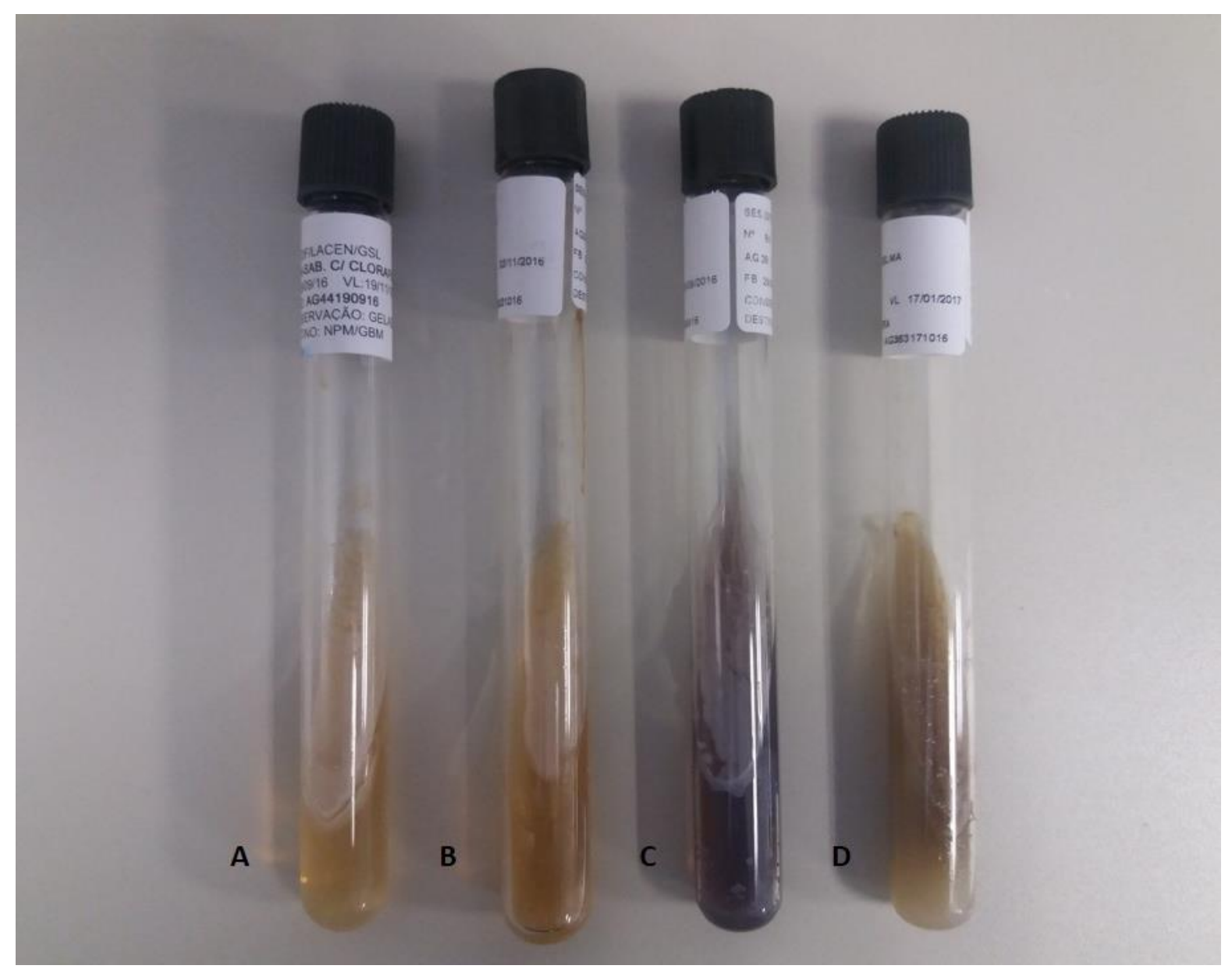

Figura 9 - Aspectos macroscópicos Cryptococcus spp. em meios de cultura

Crescimento em ágar Sabouraud (A), ágar Fava Neto (B), ágar Littman (C) e ágar Níger (D)

De forma complementar, foram realizados identificações com testes bioquímicos automatizados, utilizando-se o equipamento VITEK® 2 Compact (BioMérieux ${ }^{\circledR}$, França), os quais envolveram as reações de assimilação de carboidratos, ácidos orgânicos e nitrato e, reações de oxidase, aril-amidase e fosfatase. A realização destas provas serviu para confirmar a caracterização do $C$. neoformans, uma vez que, já era esperado a limitação na identificação do $C$. gattii, pois esta espécie não está presente no banco de dados do sistema. Todos os isolados clínicos $(\mathrm{n}=20)$ foram identificados como C. neoformans, evidenciando a limitação supracitada.

A diferenciação de $C$. neoformans e $C$. gattii deve ser realizada, pois entre estas espécies há constrastes de grande relevância clínica, como o perfil de hospedeiro e manejos clínicos, principalmente voltados a condições terapêuticas, no que tange a dosagem farmacológica, tempo de tratamento e perfil de sensibilidade aos antifúngicos. Diante ao reconhecimento do $C$. gattii como um patógeno emergente, o diagnóstico laboratorial 
diferencial entre estas espécies tornou-se sine qua non para a resolução de casos de criptococose, exigindo abordagens moleculares adicionais.

Neste estudo, utilizando a técnica PCR-RFLP, com a amplificação do gene URA5, foi identificado 12 espécies de $C$. neoformans var grubii VNI (C. neoformans) e 8 espécies de $C$. gattii VGII (C. deuterogattii), que representam respectivamente $60 \%$ e $40 \%$. Todos os isolados encontrados estão em consonância com o perfil de variantes predominantes no Brasil, entretanto as informações sobre a distribuição de espécies é bastante fragmentanda, não havendo um consenso sobre a epidemiologia referente a criptococose (FAVALESSA, et al., 2014; HERKERT et al., 2016).

Segundo Meyer e cols. (2011), o tipo molecular VNI representa $63 \%$ dos agentes etiológicos isolados em casos de criptococose no mundo inteiro, seguido de VGI ( $9 \%$ ), VGII (7 \%), VNII e VNIII (6 \% cada), VNIV (5\%), VGIII (3\%) e VGIV (1\%). Comparando os nossos dados, com os encontrados por Meyer e cols. (2011), observamos apenas dois genótipos identificados, VNI que correspondeu a $60 \%$ do genótipo $C$. neoformans var grubii isolado em nossas amostras e que corrobora com os $63 \%$ encontrados por estes pesquisadores, e o VGII que correspondeu a $40 \%$ do do genótipo $C$. gatii, No Brasil, há um estudo realizado por Trilles e cols. (2008) com isolados clínicos, que apresenta similitude, sendo encontrado os seguintes tipos moleculares: VNI (64\%) e VGII (21\%), seguido de VNII (5\%), VGIII (4\%), VGI e VNIV (3\% cada) e VNIII (<1\%), não havendo identificação do tipo molecular VGIV.

Cabe ressaltar a que a identificação das espécies de Cryptococcus e suas variantes não apresenta apenas interesse taxonômico e epidemiológico, mas também auxilia na abordagem clínica, devido aos apectos imunológicos e fatores de riscos distintos (KWON-CHUNG et al., 2014).

O C. neoformans var grubii VNI (C. neoformans) é fundamentalmente encontrado em amostras de pacientes imuncomprometidos infectados com HIV, já o $C$. gatti VGII ( $C$. deuterogattii) está associado a pacientes não infectados com HIV e crianças, caracterizando a diferença entre o perfil de hospedeiro (DOS SANTOS et al., 2008).

Da mesma forma, diferenças nos perfis de sensibilidade aos antifúngicos são encontradas para estas duas variantes.

A análise por espectrometria de massa MALDI-TOF realizada no equipamento VITEK MS® (BioMérieux ${ }^{\circledR}$, França) identificou todos os isolados como C.neoformans utilizando os bancos de dados MYLA® (BioMérieux®, França) e SARAMIS® (Shimadzu®, 
Japão), revelando a limitação deste método em termos de diferenciação de espécies e suas variantes. Tal fato deve-se a aplicabilidade recente desta técnica para identificação de leveduras e pela elevada complexidade de inserção de novos espectros nos bancos de dados existentes.
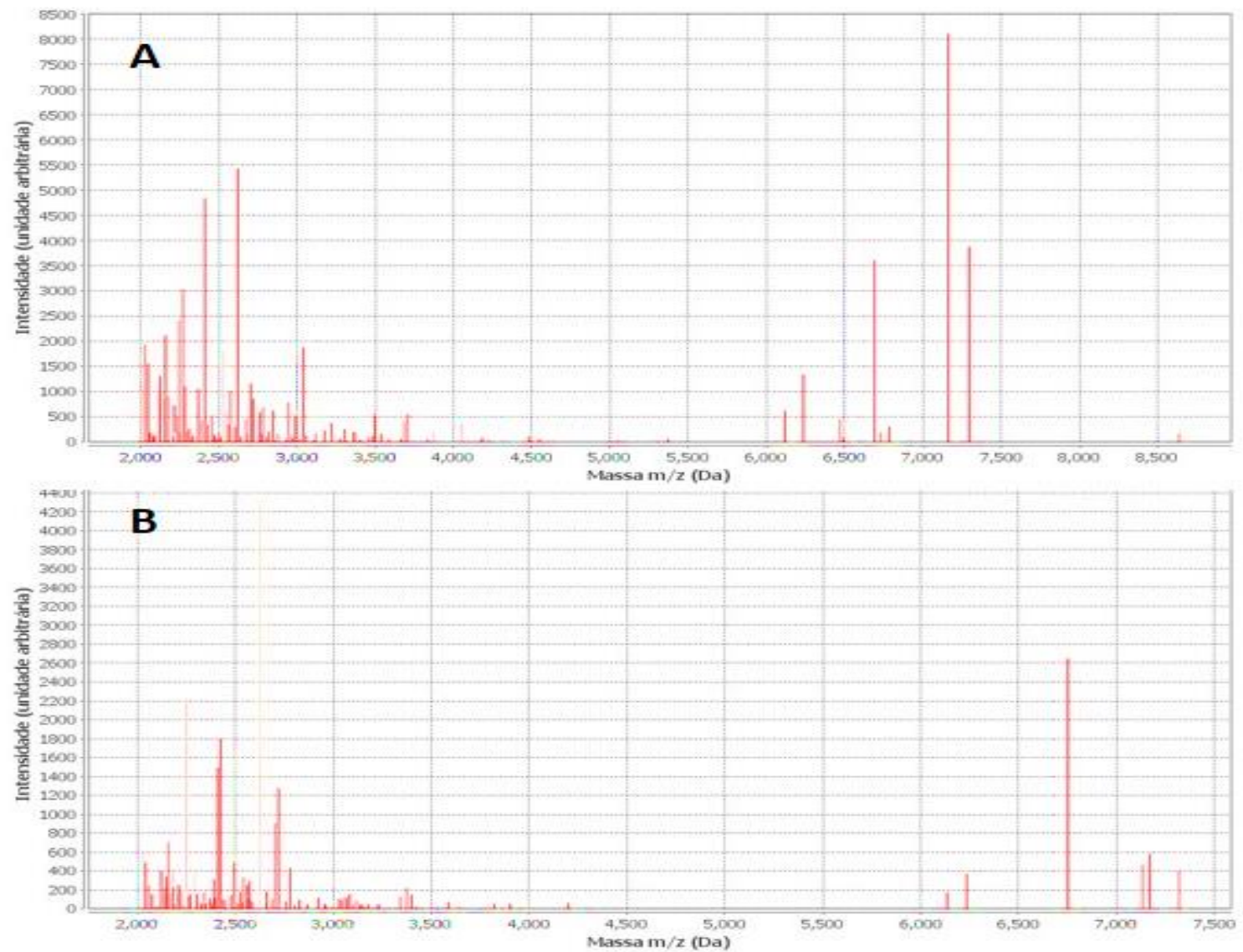

Figura 10 - Espectros de Cryptococcus na plataforma VITEK MS ® Espectros de C.neoformans (A) e C. gattii (B)

Fazendo uma comparação das técnicas empregadas neste estudo (Tabela 7), conseguimos evidenciar limitações importantes entre as metodologias utilizadas. Entre as técnicas manuais o Ágar Níger diferencia Cryptococcus spp. de outras espécies fúngicas, como Candida spp. e Trichophyton spp., já o Ágar CGB demonstra eficiência na diferenciação entre as espécies de Cryptococcus, evidenciando suas potencialidades, quanto a a utilização como testes iniciais ou de triagem.

Observando o desempenho das técnicas automatizadas VITEK 2 e VITEK MS (MALDI-TOF), novamente verificamos limitações na identificação das espécies fúngicas, e temos que ressaltar essa pouca especificidade do método empregado no equipamento VITEK 2, que é muito utilizado na prática clínica para identificação de espécies, e apresentou $100 \%$ de falha neste processo. Quanto ao MALDI-TOF, também observamos a mesma limitação 
metodológica, entretanto sabemos que ao longo do tempo e com a inserção de novos espectros de identificação, é possível que esta especificidade melhore e consequentemente a técnica seja robusta o suficiente para auxiliar nas identificações de espécies. E finalmente, observando os resultados obtidos pela técnica molecular de PCR-RFLP, podemos afirmar que o método nos permitiu identificar a espécie, sua variante genotípica e genótipo, o que além de trazer aumento de sensibilidade e principalmente especifidade metodológica, traz confiabilidade laboratorial, e ainda corrobora com o manejo clínico farmacológico dos pacientes, aumentando assim as chances de cura da micose.

Tabela 7 - Técnicas utilizadas na identificação de Cryptococcus spp.

\begin{tabular}{|c|c|c|c|c|c|c|}
\hline \multicolumn{4}{|c|}{ Técnicas manuais } & \multicolumn{2}{|c|}{$\begin{array}{c}\text { Técnicas } \\
\text { automatizadas }\end{array}$} & $\begin{array}{c}\text { Técnicas } \\
\text { moleculares }\end{array}$ \\
\hline $\begin{array}{c}\text { Tinta } \\
\text { nanquim }\end{array}$ & Ágar Uréia & Ágar Níger & Ágar CGB & $\begin{array}{c}\text { VITEK } \\
2\end{array}$ & $\begin{array}{l}\text { VITEK } \\
\text { MS }\end{array}$ & PCR-RFLP \\
\hline \multirow{2}{*}{$\begin{array}{l}\text { Leveduras } \\
\text { encapsuladas } \\
\qquad(20)\end{array}$} & $\begin{array}{c}\text { Cryptococcus spp. } \\
\text { (20) }\end{array}$ & $\begin{array}{c}C . \\
\text { neoformans } \\
(12)\end{array}$ & $\begin{array}{c}C . \\
\text { neoformans } \\
\text { (12) }\end{array}$ & \multirow{2}{*}{\multicolumn{2}{|c|}{ C. neoformans (20) }} & $\begin{array}{c}\mathrm{VNI} \\
\text { C.neoformans } \\
(12)\end{array}$ \\
\hline & & $\begin{array}{l}\text { C. gattii } \\
\text { (8) }\end{array}$ & $\begin{array}{l}\text { C. gattii } \\
\text { (8) }\end{array}$ & & & $\begin{array}{c}\text { VGII } \\
\text { C.deuterogattii } \\
(8)\end{array}$ \\
\hline
\end{tabular}

\subsection{Perfil de susceptibilidade de Cryptococcus spp.}

Para a determinação do perfil de suscetibilidade das amostras de Cryptococcus frente aos antifúngicos Anfotericina B (AB), Fluconazol (FLU) e 5-Fluorocitosina (FCT), utilizouse cartões do tipo AST-YS07 (BioMérieux®, França) compatíveis com o equipamento VITEK® 2 Compact (BioMérieux®, França) e análises confrontativas com dados epidemiológicos correntes, no intuito de se parametrizar os resultados e obter uma interpretação quanto a sensibilidade ou resistência aos antifúngicos (Tabela 8).

Os resultados foram expressos em $\mu \mathrm{g} / \mathrm{mL}$, caracterizando a CIM (Tabela 9), entretanto quando se trata de Cryptococcus spp., não há valores de referência estabelecidos para os antifúngicos em questão, por isso a necessidade de se utilizar os Epidemiologic Cut-off value (ECV), para possibilitar avaliações (ESPINEL-INGROFF, et al., 2012a e 2012b). 
Tabela 8 - ECV para drogas antifúngicas usadas no tratamento da criptococose

\begin{tabular}{lcccc}
\hline Espécie & Genótipo & Drogas Antifúngicas & Sensível $(\boldsymbol{\mu g} / \mathbf{m L})$ & Resistente $(\boldsymbol{\mu g} / \mathbf{m L})$ \\
\hline \multirow{3}{*}{ C. neoformans } & \multirow{2}{*}{ VNI } & AB & $\leq 0,5$ & $>0,5$ \\
& & FLU & $\leq 8$ & $>8$ \\
& & FCT & $\leq 8$ & $>8$ \\
C. gatti & AB & FLU & $\leq 1$ & $>32$ \\
& \multirow{2}{*}{ VGII } & FCT & $\leq 16$ & $>16$ \\
\hline
\end{tabular}

Anfotericina-B (AB), Fluconazol (FLU) e 5-Fluorositosina (FCT)

Adaptado de ESPINEL-INGROFF, et al., 2012a e 2012b

Dentre todos os isolados clínicos $(n=20)$ foram identificadas 3 situações de resistência a $\mathrm{AB}$, sendo 2 em $C$. neoformans VNI e 1 em $C$. gattii VGII, fato também elucidado em estudos anteriores, como em Da Silva e Cols, 2008 e Andrade-Silva e cols, 2013, que demonstraram resistência a AB, mas sem a descrição de seu mecanismo, entretanto pode estar associada a alteração na composição do ergosterol da membrana fúngica, em virtude de mediação por aumento da atividade da catalase e/ou defeitos na biossíntese de ergosterol (JOSEPH-HORNE et al., 1996; RODRÍGUEZ-TUDELA \& MARTINEZSUAREZ, 1997; PEMÁN, CANTÓN \& ESPINEL-INGROFF, 2009).

Tabela 9 - Resultados dos testes de susceptibilidade do Vitek 2 Compact

\begin{tabular}{|c|c|c|c|c|c|}
\hline Espécie & Genótipo & Drogas Antifúngicas & CIM $(\mu \mathrm{g} / \mathrm{mL})$ & Ocorrência & $\begin{array}{c}\text { Interpretação } \\
\text { (ECV) }\end{array}$ \\
\hline \multirow{7}{*}{ C. neoformans } & \multirow{7}{*}{ VNI } & \multirow{4}{*}{$\mathrm{AB}$} & $\leq 0,25$ & $9 / 12$ & Sensível \\
\hline & & & 0,5 & $1 / 12$ & Sensível \\
\hline & & & 1 & $2 / 12$ & Resistente \\
\hline & & & 2 & $11 / 12$ & Sensível \\
\hline & & \multirow[t]{2}{*}{ FLU } & 4 & $1 / 12$ & Sensível \\
\hline & & & $\leq 1$ & $11 / 12$ & Sensível \\
\hline & & \multirow[t]{2}{*}{ FCT } & 2 & $1 / 12$ & Sensível \\
\hline \multirow{7}{*}{ C. gattii } & \multirow{7}{*}{ VGII } & & $\leq 0,25$ & $4 / 8$ & Sensível \\
\hline & & \multirow{3}{*}{$\mathrm{AB}$} & 0,5 & $1 / 8$ & Sensível \\
\hline & & & 1 & $2 / 8$ & Sensível \\
\hline & & & 4 & $1 / 8$ & Resistente \\
\hline & & \multirow{2}{*}{ FLU } & 2 & $4 / 8$ & Sensível \\
\hline & & & 4 & $4 / 8$ & Sensível \\
\hline & & FCT & 1 & $8 / 8$ & Sensível \\
\hline
\end{tabular}

\subsection{Atividade antifúngica do extrato aquoso de Eugenia dysenterica}

A atividade antifúngica do extrato aquoso de E. dysenterica foi evidenciada contra $C$. neoformans e $C$. gattii a partir de microdiluições em placa, que permitiram a identificação de uma CIM (Tabela 10), assim como no estudo de Costa e cols. (2000) que demonstrou atividade contra Cryptococcus spp.

Alguns estudos indicam ação de outras espécies da família Myrtaceae contra Cryptococcus spp. Segundo Ferreira e cols. (2014), extratos obtidos da casca e folhas de 
Eugenia calycina possuem ação contra Cryptococcus sp., C. neoformans e C. gattii. Victoria e cols (2012), citam que extrato de folhas de E. uniflora possui atividade contra C. laurentii, assim como Lago e cols (2011), para C. neoformans e C. gattii.

Tendo em vista os resultados obtidos a partir dos estudos com extratos brutos de espécies de Eugenia percebe-se o grande potencial antifúngico desta planta, candidatando-a como para o desenvolvimento de novos fármacos, visto que os tratamentos convencionais apresentam nefrotoxicidade, hepatotoxidade e mielotoxicade (GULLO et al., 2013).

Além disso, o extrato vegetal de $E$. dysenterica deve ser considerado um fitocomplexo e não, um conjunto de substâncias isoladas, o que enaltece ainda mais sua atividade biológica. Os fitocomplexos são substâncias originadas no metabolismo primário ou secundário, ou mesmo ambos, dos extratos das plantas, e são responsáveis em sua totalidades pelos efeitos biológicos de uma planta medicinal ou de seus derivados (BRASIL, 2014). Assim sendo, poderíamos atribuir as atividades biológicas dos extratos à presença destes compostos ativos, que podem agir sigergicamente e também conferir efeitos diretos e indiretos. $\mathrm{O}$ efeito direto refere-se a sua ação farmacológica, enquanto o indireto às interações simultâneas com outras plantas ou fármacos (MARTINS et al., 2015).

Analisando os resultados da Concentração Inibitória Mínima (CIM) obtidas com o extrato aquoso de E. dysenterica (Tabela 10), podemos afirmar que os valores obtidos apresentam potencialidade fungicida relevante, principalmente se considerarmos que houve resistência a um antifúngico usual no tratamento da criptococose, a Anfotericina B.

Contudo, são necessários mais estudos para avaliar o potencial antifúngico de $E$. dysenterica e possíveis ações sinérgicas com demais antifúngicos comerciais, assim como estabelecer claramente mecanismos de ação e validar sua eficácia em estudos in vivo.

Tabela 10 - CIM de FLU (controle) e E. dysenterica

\begin{tabular}{ccccc}
$\begin{array}{c}\text { Identificação } \\
\text { molecular } \\
\text { (PCR-RFLP) }\end{array}$ & $\begin{array}{c}\text { Espécie } \\
\text { identificada }\end{array}$ & $\begin{array}{c}\text { CIM (FLU - controle) } \\
\boldsymbol{\mu g} / \mathbf{m L}\end{array}$ & $\begin{array}{c}\text { CIM (E. dysenterica) } \\
\boldsymbol{\mu g} / \mathbf{M l}\end{array}$ & Ocorrência \\
\hline \multirow{2}{*}{ C.gattii } & & 1,95 & $>100000$ & $2 / 8$ \\
& & 3,9 & 24 & $2 / 8$ \\
VGII & 3,9 & $>1000$ & $1 / 8$ \\
& & 3,9 & 390 & $1 / 8$ \\
& & 1,95 & 24 & $1 / 8$ \\
& & 3,9 & 48 & $2 / 12$ \\
VNI & & 1,95 & 100000 & $1 / 12$ \\
& & 1,95 & 195 & $1 / 12$ \\
& & 1,95 & 24 & $1 / 12$ \\
\hline
\end{tabular}




\section{CONCLUSÕES}

Os resultados apresentados neste estudo, nos permitem concluir que:

O LCR foi o espécime clínico predominante, que correspondeu a $75 \%$ do total de amostras analisadas, e apenas neste material biológico foi possível visualisar estruturas leveduriformes encapsuladas correspondente ao Cryptococcus spp.

A utilização de ágar CGB permitiu a diferenciação dos isolados em C. neoformans e C. gattii, havendo predomínio do primeiro $(60 \%)$ frente ao segundo (40\%), ressaltando a importância dessa metodologia para a triagem na identificação das espécies.

Os testes bioquímicos automatizados realizados na plataforma VITEK® 2 Compact (BioMérieux ${ }^{\circledR}$, França) identificou todos os isolados como C. neoformans, revelando sua limitação quanto a diferenciação entre espécies de Cryptococcus.

A análise por espectofotometria de massa revelou-se insuficiente para a identificação de espécies e variantes de Cryptococcus spp. uma vez que, ainda possui um banco de dados limitado, não havendo espectros padrões de $C$. gattii para se realizar as correlações.

A técnica molecular PCR-RFLP possibilitou a diferenciação de espécies e suas variantes, identifcando 12 espécies de $C$. neoformans var grubii VNI (C. neoformans) e 8 espécies de $C$. gattii VGII (C. deuterogattii), que representam respectivamente $60 \%$ e $40 \%$. Estes resultados concordaram com os resultados em ágar CGB e com os padrões epidemiológicos encontrados em estudos nacionais e internacionais.

São necessárias combinações entre métodos clássicos manuais empregados para a triagem na identificação das espécies de Cryptococcus, e o método molecular PCR-RFLP, que juntos complementam para a identificação das espécies de Cryptococcus spp.

Para a determinação do perfil de suscetibilidade das amostras de Cryptococcus frente aos antifúngicos AB, FLU e FCT utilizou-se cartões do tipo AST-YS07 (BioMérieux®, França) no equipamento VITEK® 2 Compact (BioMérieux ${ }^{\circledR}$, França) e constatou-se 3 situações de 
resistência a $\mathrm{AB}$, sendo 2 em $C$. neoformans VNI e 1 em $C$. gattii VGII. Os valores de CIM obtidos foram comparados com valores epidemiológicos convencionados. Como não há valores de referência estabelecidos para os antifúngicos em questão, utilizamos Epidemiologic Cut-off value (ECV).

O extrato aquoso de folhas de $E$. dysenterica apresentou atividade antifúngica contra $C$. neoformans e $C$. gattii, mesmo para as cepas que apresentaram resistência a antifúngicos empregados na terapêutica como a Anfotericina B. Considerando o fato de o extrato ser um fitocomplexo, podemos afirmar que há perspectivas em considerá-lo com potencial para o desenvolvimento de novos fármacos, e também para o isolamento de novas substâncias com atividade fungicida, o que traria novos tratamentos com menos toxicidade e melhores chances de cura para os casos de resistência a antifúngicos convencionais.

De maneira geral, os resultados do estudo apontam estratégias metodológicas que devem ser empregadas na prática laboratorial para a correta identificação da espécie e variante do fungo Cryptococcus, bem como a implantação de antifungigrama com as drogas mais usuais, mesmo sem valores de referências de CIM totalmente padronizados, o que traria a estes pacientes uma perspectiva de diagnóstico laboratorial mais precisa e consequentemente diagnóstico clínico e tratamento farmacológico mais eficientes. Além disso, a $E$. dysenterica apresentou potencialidades fungicidas evidentes para estas espécies fúngicas, cada vez mais prevalentes em nosso meio e com pouco arsenal terapêutico convencional disponível, o que faz esta micose ter relevante taxa de mortalidade no Brasil e no mundo, e ser considerada um problema de saúde pública emergente. 


\section{REFERÊNCIAS}

ALBUQUERQUE, P. C.; RODRIGUES, M. L. Research trends on pathogenic Cryptococcus species in the last 20 years: a global analysis with focus on Brazil. Future Microbiol, v. 7, p. 319-329, 2012.

ALMEIDA, S. P.; PROENÇA, C. E. B.; SANO, S. M.; RIBEIRO, J. F. Cerrado: espécies vegetais úteis. Empresa Brasileira de Pesquisa Agropecuária editor. Planaltina, DF: EMBRAPA, p. 464, 1998.

AMARO, M. C. O. Caracterização de isolados clínicos de Cryptococcus neoformans e Cryptococcus gatti quanto à susceptibilidade a fluconazol. Dissertação de Mestrado Programa de Pós-Graduação em Biologia Celular e Molecular, 2006.

ANDRADE-SILVA, L.; et al. Susceptibility profile of clinical and environmental isolates of Cryptococcus neoformans and Cryptococcus gattii in Uberaba, Minas Gerais, Brazil. Med Mycol., v. 51, p. 635-640, 2013.

ASSOB, J. C. N.; KAMGA, H. L. F.; NSAGHA, D.S.; NJUNDA, A.L.; NDE, P.F.; ASONGALEM, E. A.; NJOUENDOU, A. J.; SANDJON, B.; PENLAP, V. B;. Antimicrobial and toxicological activities of five medicinal plant species from Cameroon traditional medicine. BMC Compl Altern Med, v.11, p. 1-27, 2011.

ASSOGBA, K.; et al. Neuromeningeal cryptococcosis in sub-Saharan Africa: killer disease with sparse data. J. Neurosci. Rural Pract, v. 6, p. 221-224, 2015.

ARAÚJO JÚNIOR, E. C.; TÁRPARO, C.V.; UCHIDA, C.Y.; MARINHO, M. Cryptococcus: isolamento ambiental e caracterização bioquímica. Arq. Bras. Med. Vet. Zootec, v .67, 2015.

ARVANITIS, M. et al. Molecular and nonmolecular diagnostic methods for invasive fungal infections. Clinical Microbiology Reviews, v. 27, p. 490-526, 2014.

BAGINSKI, M.; CZUB, J. Amphotericin B and Its New Derivatives - Mode of Action. Current Drug Metabolism, v. 10, p. 459-469, 2009.

BAHN, Y. S.; JUNG, K. W. Stress signaling pathways for the pathogenicity of Cryptococcus. Eukaryot Cell, v. 12, p. 1564-1577, 2013.

BARBOSA JÚNIOR, A. M.; SANTOS, B. F. O.; CARVALHO, E. O.; MELO, D. L. F. M.; TRINDADE, R. C.; STOIANOFF, M. A. R. Biological activity of Cryptococcus neoformans and Cryptococcus gattii from clinical and environmental isolates. Jornal Brasileiro de Patologia e Medicina Laboratorial, v. 49, 2013.

BATTISTI, C.; GARLET, T. M. B.; ESSI, L.; HORBACH, R. K.; ANDRADE, A.; BADKE, M . R. Plantas medicinais utilizadas no município de Palmeira das Missões, RS, Brasil. Revista Brasileira de Biociências, v. 11, p. 338-348, 2013. 
BIVANCO, F. C.; MACHADO, C. D. S.; MARTINS, E. L. Criptococose cutânea. Arq Med ABC, v. 31, p. 102-109, 2006.

BENADUCCI, T.; SARDI, J. C. O.; LOURENCETTI, N. M. S.; SCORZONI, L.; GULLO F. P.; ROSSI, S. A.; DERISSI, J. B.; PRATA, M. C. A.; FUSCO-ALMEIDA, A. M.; MENDESGIANNINI, M. J .S. Virulence of Cryptococcus spp.. Biofilms In Vitro and In Vivo using Galleria mellonella as an Alternative Model. Front. Microbiol, v. 9, 2016.

BERGOLD, A. M.; GEORGIADIS, S.; Novidades em fármacos antifúngicos: uma revisão. Visão Acadêmica, v. 5, p. 159 -172, 2004.

BICANIC, T.; MEINTJES, G.; WOOD, R.; HAYES, M.; REBE, K.; et al. Fungal burden, early fungicidal activity, and outcome in cryptococcal meningitis in antiretroviral-naive or antiretroviral-experienced patients treated with amphotericin B or fluconazole. Clin Infect Dis, v. 45, p.76-80, 2007.

BOEKHOUT, T.; THEELEN, B.; DIAZ, M.; FELL, J.W.; HOP, W.C.J.; ABELN, E.C.A.; DROMER, F. ; MEYER, W. Hybrid genotypes in the pathogenic yeast Cryptococcus neoformans. Microbiology, v. 147, p. 891-907, 2001.

BOVERS, M.; HAGEN, F.; BOEKHOUT, T. Diversity of the Cryptococcus neoformans/Cryptococcus gattii species complex. Revista Iberoamericana de Micologia, v. 25, p. 4-12, 2008.

BRATTON, E. W.; et al. Comparison and temporal trends of three groups with cryptococcosis: HIV-infected, solid organ transplant, and HIV-negative/non-transplant. PLoS ONE, v.7, 2012.

BRASIL. Resolução RDC $\mathrm{n}^{\circ} 26$ de 13 de maio de 2014. Dispõe sobre o "Registro de medicamentos fitotérapicos e o registro e a notificação de produtos tradicionais fitoterápicos". Órgão emissor: ANVISA - Agência Nacional de Vigilância Sanitária. Disponível em: www.anvisa.gov.br. Acesso em: 15 de maio de 2016.

BRITO, M. A.; PEREIRA, E. B. C.; PEREIRA, A. V.; RIBEIRO, J. F. Cagaita: biologia e manejo. Empresa Brasileira de Pesquisa Agropecuária editor. Planaltina, DF: EMBRAPA, 2003.

BUCHANAN, K. L.; MURPHY, J. W. What makes Cryptococcus neoformans a pathogen? Emerg Infect Dis, v. 4, p. 71-83, 1998.

BYRNES, E. J.; BILDFELL, R. J.; FRANK, S. A.; MITCHELL, T. G.; MARR, K.A.; et al. Molecular evidence that the range of the Vancouver Island outbreak of Cryptococcus gattii infection has expanded into the Pacific Northwest in the United States. J Infect Dis, v.199: p. 1081-1086, 2009a.

BYRNES, E. J.; LI, W.; LEWIT, Y.; PERFECT, J. R.; CARTER, D. A.; COX, G. M; et al. First Reported Case of Cryptococcus gattii in the Southeastern USA: Implications for TravelAssociated Acquisition of an Emerging Pathogen. PLoS ONE, v. 4, $2009 \mathrm{~b}$. 
CAMPOS, F. L.; BARONI, F. A. Isolados de Cryptocococcus neoformans, $C$. gattii e $C$. laurentii produtores de protease e fosfolipase. Revista de Patologia Tropical, v.39, p. 83-89, 2010.

CAMILO, Y. M. V.; SOUZA, E. R. B.; VERA, R.; NAVES, R. V. Caracterização de frutos e seleção de progênies de cagaiteiras (Eugenia dysenterica DC.). Científica, v. 42, p. 1-10, 2014.

CARRILLO-MUÑOZ, A. J.; GIUSIANO, G.; EZKURRA, P. A.; QUINDÓS, G. Antifungal agentes: Mode of action in yeast cells. Rev. Esp. Quimioterap., v. 19, p. 130-139, 2006.

CASADEVAll, A.; PERFECT, J. R. Cryptococcus neoformans. American Society for Microbiology, Washington, DC, 1998.

CASALI, A. K.; GOULART, L.; ROSA E SILVA, L. K.; RIBEIRO, A. M.; AMARAL, A. A.; ALVES, S. H.; SCHRANK, A.; MEYER, W.; VAINSTEIN, M. H. Molecular typing of clinical na environmental Cryptocococcus neoformans in the Brazilian State Rio Grande do Sul. FEMS Yeast Res, v. 3, p. 405-415, 2003.

CECÍlIO, A. B. FARIA, D. B.; OLIVEIRA, P. C.; CALDAS, S.; OLIVEIRA, D. A.; SOBRAL, M. E. G.; et al. Screening of Brazilian medicinal plants for antiviral activity against rotavirus. Journal of Ethnopharmacology, v. 141, p. 975-981, 2012.

CHAPELAND-LECLERC, F.; BOUCHOUX, J.; GOUMAR, A.; CHASTIN, C.; VILLARD, J.; NOÉ, T. Inactivation of the FCY2 Gene Encoding Purine-Cytosine Permease Promotes Cross-Resistance to Flucytosine and Fluconazole in Candida lusitaniae. Journal List Antimicrob Agents Chemother, v. 49, 2005.

CHATURVEDI, V.; WONG, B.; NEWMAN, S. L. Oxidative killing of Cryptococcus neoformans by human neutrophils. Evidence that fungal mannitol protects by scavenging reactive oxygen intermediates. The Journal of Immunology, v. 156, p. 3836-3840, 1996.

CLSI. Method for Antifungal Disk Diffusion Susceptibility Testing of Yeasts: Approved Guideline. Waine, Pensilvânia - USA, 2004.

COENJAERTS, F. E. J. The sixth International Conference on Cryptococcus and Cryptococcosis. FEMS. Yeats Res, v. 6, p. 312-317, 2006.

COGLIATI, M. Global molecular epidemiology of Cryptococcus neoformans and Cryptococcus gattii: an atlas of the molecula. Scientifica (Cairo), 2013.

COGLIATI, M.; ZANI, A.; RICKERTS, V.; MCCORMICK, I.; DESNOS-OLLIVIER, M.; VELEGRAKI, A.; ESCANDON, P.; ICHIKAWA, T.; IKEDA, T.; et al. Multilocus sequence typing analysis reveals that Cryptococcus neoformans var. neoformans is a recombinant population. Fungal Genetics and Biology, v. 87, p. 22-29, 2016.

COLOMBO, A. C.; RODRIGUES, M. L. Fungal colonization of the brain: anatomopathological aspects of neurological cryptococcosis. An. Acad. Bras. Ciênc, v.87, 2015. 
COLOMBO, G; TÁPARO, C.V.; ARAÚJO JÚNIOR, E.C.; MAKATU, M. Y.; SANTOS, F.S.; MARINHO, M. Biochemical and molecular characterization of Cryptococcus spp. isolates from environmental feces of pigeons (Columba livia domestic). Arquivo Brasileiro de Medicina Veterinária e Zootecnia, v. 67, 2015.

COSTA, A. K. F. Análise fenotípica e molecular de cepas de Cryptococcus spp obtidas de fontes ambientais e clínicas. Tese apresentada ao Programa de Pós-Graduação em Ciências Veterinárias da Faculdade de Veterinária da Universidade Estadual do Ceará, 2009.

COSTA, C. R.; LULI, F. B. D.; CARNEIRO, J. R.; CARDOSO, A. M. Infecções fúngicas em pacientes HIV positivos: Revisão da literatura sobre criptococose e histoplasmose. Estudos, v. 41, p. 843-854, 2014.

COSTA, T. R.; et al. Antifungal activity of volatile constituents of Eugenia dysenterica leaf oil. Journal of Ethnopharmacology, v. 72, p. 111-117, 2000.

CORREA, M. P. S. C.; OLIVEIRA, E. C.; DUARTE, R. R. B. S.; PARDAL, P. P. O.; OLIVEIRA, F. M.; SEVERO, L. C. Criptococose em crianças no estado do Pará, Brasil. Revista da Sociedade Brasileira de Medicina Tropical, v. 32, p. 505-508, 1999.

CORREIA, A. F.; et al. Activity of crude extracts from Brazilian cerrado plants against clinically relevant Candida species. BMC Complement Altern Med, v. 16, 2016

CORREIA, A. F.; SEGOVIA, J. F. O.; GONÇALVES, M. C. A.; OLIVEIRA, V. L.; SILVEIRA, D; CARVALHO, J. C. T.; KANZAKI, L. I. B. Amazonian plant crude extract screening for activity against multidrug-resistant bacteria. Eur Rev Med Pharmacol Sci, v. 12, p. 369-380, 2008.

COX, G. M.; MUKHERJEE, J.; COLE, G. T.; CASADEVALL, A.; PERFECT, J. R. Urease as a virulence factor in experimental cryptococcosis. Infect Immun, v. 68, p. 443-448, 2000.

DARZÉ C.; LUCENA, R.; GOMES, I.; MELO, A. Clinical and laboratory characteristics of 104 cryptococcus meningoencephalitis cases. Revista da Sociedade Brasileira de Medicina Tropical, v. 33, p. 21-26, 2000.

DA SILVA, P. R.; et al. Suscetibilidade a antifúngicos de variedades de Cryptococcus neoformans isoladas de pacientes em hospital universitário. Rev. Soc. Bras. Med. Trop., v.41, 2008.

DATTA, K.; BARTLETT, K. H.; BAER, R.; BYRNES, E.; GALANIS, E.; et al. Spread of Cryptococcus gattii into Pacific Northwest region of the United States. Emerg Infect Dis, v. 15, p. 1185-1191, 2009.

DE CAROLIS, E.; VELLA, A.; VACCARO, L.; TORELLI, R.; SPANU, T.; FIORI, B.; POSTERARO, B.; SANGUINETTI, M. Application of MALDI-TOF mass spectrometry in clinical diagnostic microbiology. J Infect Dev Ctries, v. 8, p. 1081-1088, 2014.

DE HOOG, G. S.; GUARRO, J.; GENE, J.; FIGUERAS, M. J. Atlas of Clinical Fungi. Centraalbureau voor Schimmelcultures, Utrecht, The Netherlands. 2000. 
DOERING, T. L. How sweet it is! Cell wall biogenesis and polysaccharide capsule formation in Cryptococcus neoformans. Annu Rev Microbiol, v. 63, p. 223-247, 2009.

DOLANDE FRANCO, M. Factores de virulencia e inmunidad en criptococosis. Revista de la Sociedad Venezolana de Microbiología, v. 21, 2011.

DORA, C. L.; SOUZA, L. C. Novas formas comerciais de anfotericina B. Revista de Ciências Médicas, v. 42, p. 187-197, 2005.

DORIGONI, P. A.; GHEDINI, P. C.; FRÓES, L. F.; BAPTISTA, K. C.; ETHUR, A. B. M.; BALDISSEROTTO, B.; BÜRGER, M. E.; ALMEIDA, C. E.; LOPES, A.M.; ZÁCHIA, R. A. Levantamento de dados sobre plantas medicinais de uso popular no município de São João do Polêsine, RS, Brasil. I - Relação entre enfermidades e espécies utilizadas. Revista Brasileira de Plantas Medicinais, v. 4, p. 69-79, 2001.

DOS SANTOS, W. R. A. et al. Primary endemic Cryptococcosis gattii by molecular type VGII in the state of Pará, Brazil. Mem. Inst. Oswaldo Cruz, v.103, 2008.

DROMER, F.; BERNEDE-BAUDUIN, C.; GUILLEMOT, D.; LORTHOLARY, O. Major role for amphotericin B-flucytosine combination in severe cryptococcosis. PLoS ONE, v.3, 2008 .

DUARTE, A. et al. Genetic and Environmental Influence on Essential Oil Composition of Eugenia dysenterica. Journal of the Brazilian Chemical Society, v. 21, p. 1459-1467, 2010.

DUBOC, E.; GUERRINI, I. A. Desenvolvimento inicial e nutrição da cagaita em áreas de cerrado degradado. Empresa Brasileira de Pesquisa Agropecuária editor. Planaltina, DF: EMBRAPA, 2007;

EISENMAN, H.C.; CASADEVALL, A. Synthesis and assembly of fungal melanin. Appl Microbiol Biotechnol, v. 93, p. 931-940, 2012.

ELLIS, D.H.; PFEIFFER, T. J. Natural habitat of Cryptococccus neoformans var. gattii. J Clin Microbiol, v. 28, p. 1642-1644, 1990.

ENACHE-ANGOULVANT, A.; CHANDENIER, J.; SYMOENS, F.; LACUBE, P.; BOLOGNINI, J.; DOUCHET, C.; POIROT, J. L.; HENNEQUIN, C. Molecular identification of Cryptococcus neoformans serotypes. Journal of Clinical Microbiology, v. 45, p. 1261$1265,2007$.

ESPINEL-INGROFF, A.; CHOWDHARY, A.; CUENCA-ESTRELLA, M.; FOTHERGILL, A.; FULLER, J.; et al. Cryptococcus neoformans/Cryptococcus gattii species complex: an international study of wild-type susceptibility endpoint distributions and epidemiological cutoff values for amphotericin B and flucytosine. Antimicrob Agents Chemother, v. 56, p. 3107-3113, 2012a.

ESPINEL-INGROFF, A.; ALLER, A. I.; CANTON, E.; CASTANON-OLIVARES, L. R.; CHOWDHARY, A.; et al. Cryptococcus neoformans/Cryptococcus gattii species complex: an international study of wild-type susceptibility endpoint distributions and epidemiological 
cutoff values for fluconazole, itraconazole, posaconazole, and voriconazole. Antimicrob Agents Chemother, v. 56, p. 5898-5906, 2012b.

FAGANELLO, J.; ARRUDA, W.; SCHRANK, A.; VAINSTEIN, M. H. An alternative method to prepare samples of the pathogenic yeast Cryptocococcus neoformans for scanning electron microscopy analysis. Journal of Clinical Microbiology, v. 64, p. 416-419, 2006.

FAVALESSA, O. C.; et al. Molecular typing and in vitro antifungal susceptibility of Cryptococcus spp from patients in Midwest Brazil. J Infect Dev Ctries., v. 13, p. 1037-1043, 2014.

FARIA, R. O.; NASCENTE, P. S.; MEINER, A. R. M.; CLEFF, M. B.; ANTUNES, T. A.; NOBRE, M. O.; MEIRELES, M. C. A.; MELLO, J. R. B. Occurrence of Cryptococcus neoformans in pigeon excrement in the city of Pelotas, State of Rio Grande do Sul. Revista da Sociedade Brasileira de Medicina Tropical, v. 43, p. 198-200, 2010.

FARIA JÚNIOR, J. E. Q. O gênero Eugenia L.(Myrtaceae) nos estados de goiás e tocantins, Brasil [Dissertation]. Brasília: Universidade de Brasília, 2010.

FERNANDES, O. F. L.; COSTA, T. R.; COSTA, M. R.; SOARES, A. J. S.; PEREIRA, A. J. S. C.; SILVA, M. R. R. Cryptococcus neoformans isolados de pacientes com AIDS. Revista da Sociedade Brasileira de Medicina Tropical, v. 33, p. 75-78, 2000.

FERREIRA, F. P. S., et al. Eugenia calycina Cambess extracts and their fractions: Their antimicrobial activity and the identification of major polar compounds using electrospray ionization FT-ICR mass spectrometry. Journal of Pharmaceutical and Biomedical Analysis, v. 99, p. 89 - 96, 2014.

FILIPPIN, F. B.; SOUZA, L. C. Eficiência terapêutica das formulações lipídicas de anfotericina B. Revista Brasileira de Ciências Farmacêuticas, v. 42, n. 2, p. 167-193, 2006.

FISHER, F.; COOK, N. B. Micologia: fundamentos e diagnóstico. Revinter, p. 337, 2001.

FLEVARI, A. et al. Treatment of invasive candidiasis in the elderly: a review. Journal of Clinical Interventions in Aging, v. 8, p. 1199-1208, 2013.

FRANZOT, S. P.; HAMDAN, J. S.; CURRIE, B. P.; CASADEVALL, A. Molecularepidemiology of Cryptococcus neoformans in Brazil and the United States: evidence for both local genetic differences and a global clonal population structure. J. Clin. Microbiol, v. 35, p. 2243-2251, 1997.

FRIES, B. C.; TABORDA, C. P.; SERFASS, E.; CASADEVALL, A. Phenotypic switching of Cryptocococcus neoformans occurs in vivo and influence the outcome of infection. $\mathbf{J}$ Clin Invest, v. 108, p. 1639-1648.

FRIESE, G.; DISCHER, T.; FUSSLE, R.; et al.. Development of azole resistance during fluconazole maintenance therapy for AIDS associated cryptococcal disease. AIDS, v.15, p. 2344-2345. 
GALANIS, E.; HOANG, L.; KIBSEY, P.; MORSHED, M.; PHILLIPS, P. Clinical presentation, diagnosis and management of Cryptococcus gattii cases: Lessons learned from British Columbia. Can J Infect Dis Med Microbiol, v. 20, p. 23-28, 2009.

GHANNOUM, M. A. Potential role of phospholipases in virulence and fungal pathogenesis. Clin. Microbiol. Rev, v. 13, p. 122-143, 2000.

GHANNOUM, M. A.; RICE, L. B. Antifungal agents: mode of action, mechanisms of resistance, and correlation of these mechanisms with bacterial resistance. Clinical Microbiology Reviews, v. 12, p. 501-517, 1999.

GOMES, F. S.; SARMENTO, D. N.; ESPÍRITO SANTO, E. P. T.; SILVA, H. M. Quimiotipagem e caracterização fenotípica de Cryptococcus isolados em Belém, Estado do Pará, Brasil. Rev Pan-Amaz Saude, v.1, 2010.

GOVENDER, N. P.; MEINTJES, G.; BICANIC, T.; DAWOOD, H.; HARRISON, T. S.; JARVIS, N.; KARSTAEDT, S.; MAARTENS, G.; MCCARTHY, K. M.; et al. Guideline for the prevention, diagnosis and management of cryptococcal meningitis among HIV-infected persons: 2013 update. Sajhivmed, v. 14, p. 76-86, 2013.

GULLO, E. P.; et al. Cryptococcosis: epidemiology, fungal resistance, and new alternatives for treatment. Eur J Clin Microbiol Infect Dis, 2013.

GUTCH, R. S.; NAWANGE, S. R.; SINGH, S. M.; YADU, R.; TIWARI, A.; GUMASTA, R.; KAVISHWAR, A. Antifungal susceptibility of clinical and environmental Cryptococcus neoformans and Cryptococcus gattii isolates in Jabalpur, a city of Madhya Pradesh in Central India. Brazilian Journal of Microbiology, v. 46, 2015.

HAGEN, F.; KHAYHAN, K.; THEELEN, B.; KOLECKA, A.; POLACHECK, I.; SIONOV, E.; FALK, R.; PARNMEN, S.; THORSTEN LUMBSCH, H.; BOEKHOUT, T.. Recognition of seven species in the Cryptococcus gattii/Cryptococcus neoformans species complex, Fungal Genetics and Biology, 2015.

HARRINGTON, B. J.; HAGEAGE, G. J. Calcofluor White: A Review of its Uses and Applications in Clinical Mycology and Parasitology. Your Lab Focus: Laboratory medicine, v. 34, p. 361-367, 2003.

HATA, J. D. et al. Multicenter Evaluation of the New VITEK 2 Advanced Colorimetric Yeast Identification Card Journal of Clinical Microbiology, v. 45, n. 4 , p. 1087-1092, 2007.

HAYNES, B. C.; SKOWYRA, M. L.; et al. Toward an Integrated Model of Capsule Regulation in Cryptococcus neoformans. PLoS Pathog, v. 7, p.1, 2011.

HERKERT, P. F. et al. Molecular characterisation and antifungal susceptibility of clinical Cryptococcus deuterogattii (AFLP6/VGII) isolates from Southern Brazil. Eur J Clin Microbiol Infect Dis., v.35, p. 1803-1810, 2016.

HENAO-MARTÍNEZ, A. F.; BECKHAM, J. D. Cryptococcosis in solid organ transplant recipients. Curr. Opin. Infect. Dis, v. 28, p. 300-307, 2015. 
HUSTON, S. M.; MODY, C. H. Cryptococcosis: an emerging respiratory mycosis. Clinics in Chest Medicine, v. 30, p. 253-264, 2009.

JACKSON, N. A.; HERRING, D. B. Primary capsule-deficient cutaneous cryptococcosis in a sporotrichoid pattern in an immunocompetent host. Cutis, v. 9, p. 26-29, 2015.

JACOBSON, E. S. Pathogenic Roles of Fungal Melanins. Clin Microbiol Rev, v.13, p. 708$717,2000$.

JOSEPH-HORNE, T. et al. Amphotericin B resistant isolates of Cryptococcus neoformans without alteration in sterol biosynthesis. J Med Vet Mycol, v. 34, p. 223-225, 1996

KIDD, S.E.; CHOW, Y.; MAK, S.; BACH, P. J.; CHEN, H,; et al. Characterization of environmental sources of the human and animal pathogen Cryptococcus gattii in British Columbia, Canada, and the Pacific Northwest of the United States. Appl Environ Microbiol, v. 73, p. 1433-1443, 2007.

KIM, S. H. et al. Misidentification of Candida guilliermondii as Candida famata among strains isolated from blood cultures by the VITEK 2 system. BioMed Research International, p. 1-6, 2014.

KLEIN, K. R.; HALL, L.; DEML, S. M.; RYSAVY, J. M.; WOHLFIEL, S. L. Identification of Cryptococcus gattii by use of L-canavanine glycine bromothymol blue medium and DNA sequencing. J Clin Microbiol, v. 47, p. 3669-3672, 2009.

KWONG-CHUNG, J.; BENNETT, J. Medical Mycology, Philadelfia, PA, 1992.

KWON-CHUNG, J.; FELL, J. W. Filobasidiella. Kwong-Chung. In: Kreger van Rij (ed.). The yeast: a taxonomic study. Elsevier Science Publishers, p.467-495, 1987.

KWON-CHUNG, J.; et al. Cryptococcus neoformans and Cryptococcus gattii, the Etiologic Agents of Cryptococcosis. Cold Spring Harb Perspect Med, v.4, 2014.

LACAZ, C. S.; PORTO, E.; MARTINS, J. E. C.; HEINS-VACCARI, E. M.; MELO. Tratado de Micologia Médica. São Paulo. Sarvier, p. 416-435, 2002.

LAGO, J. H. G., et al. Chemical and Biological Evaluation of Essential Oils from Two Species of Myrtaceae - Eugenia uniflora L. and Plinia trunciflora (O. Berg) Kausel. Molecules, v. 16, p. 9827-9837, 2011.

LARONE, D. H. Medically Important Fungi: a Guide to Identification. Washington: ASM PRESS, p. 136, 1995.

LATOUCHE, G.N.; HUYNH, M.; SORRELL, T.C.; MEYER, W. PCR-Restriction FragmentLength Polymorphism Analysis of the Phospholipase B (PLB1) Gene for Subtyping of Cryptococcus neoformans Isolates. Appl. Environ. Microbiol., v. 69, p. 2080-2086, 2003.

LAZÉRA, M. S.; IGREJA, R. P.; WANKE, B. Criptococose. In: SIDRIM, J. J. C.; ROCHA M. F. G. Micologia Médica: Á luz de autores contemporâneos. Rio de Janeiro: Editora Guanabara Koogan S.A., p. 89-101, 2004. 
LEITE JR, D. P.; AMADIO, J. V. R. S.; MARTINS, E. R.; SIMÕES, S. A. A.; et al.. Cryptococcus spp isolated from dust microhabitat in Brazilian libraries. Journal of Occupational Medicine and Toxicology, 2012.

LEV, S.; LI, C.; DESMARINI, D.; SAIARDI, A.; FEWINGS, N. L.; SCHIBECI, S. D.; SHARMA, R.; SORRELL, T.C.; DJORDJEVIC, J.T. Fungal inositol pyrophosphate IP7 is crucial for metabolic adaptation to the host environment and pathogenicity. mBio, v. 6, 2015.

LEV, S.; LI, C.; DESMARINI, D.; SAIARDI, A.; FEWINGS, N. L.; SCHIBECI, S. D.; SHARMA, R.; SORRELL, T.C.; DJORDJEVIC, J.T. Identification of a major IP5 kinase in Cryptococcus neoformans confirms that PP-IP5/IP7, not IP6, is essential for virulence. Scientific Reports, v.6, 2016.

LEVITZ, S. M.; BOEKOUT, T. Cryptococcus: the once sleeping-giant is fully awake. FEMS Yeast Research, v. 6, p. 461-462, 2006.

LIN, X. Cryptococcus neoformans: Morphogenesis, infection, and evolution. Infection, Genetics and Evolution, v. 9, p. 401-416, 2009.

LIU, Y.; QUNPENG, H.; SHUTIAN, X.; HONGLANG, X. Fatal primary cutane.ous cryptococcosis: case report and review of published literature. Ir J Med Sci, 2015.

LOCKHART, S. R.; IQBAL, N.; et al. Cryptococcus gattii in the United States: Genotypic Diversity of Human and Veterinary Isolates. PLoS ONE, v. 8, p. 1, 2013.

LOPERENA-ALVAREZ, Y.; REN, P.; LI, X.; BOPP, D.J.; RUIZ, A; et al. Genotypic characterization of environmental isolates of Cryptococcus gattii from Puerto Rico. Mycopathologia, v.170: p. 279-285, 2010.

LORENZI, H. Arvores Brasileiras: manual de identificação e cultivo de plantas arbóreas nativas do Brasil. Editora UFV, p. 368, 2002..

LOURENÇO, A. Site: http://www.microbiologia.vet.br. Microbiologia, acessado dia 18 de dezembro as 22:13, 2015.

MANDAL, P.; ROY, T. S.; DAS, T. K.; BANERJEE, U.; XESS, I.; NOSANCHUK, J. D. Differences in the cell wall architecture of melanin lacking and melanin producing Cryptococcus neoformans clinical isolates from India: an electron microscopic study. Braz. J. Microbiol, v. 38, 2007.

MARRA, R. E.; HUANG, J. C.; FUNG, E.; NIELSEN, K.; HEITMAN, J.; VILGALYS, R.; MITCHELL, T. G. A genetic linkage map of CryptococcuJs neoformans variety neoformans serotype D (Filobasidiella neoformans). Genetics. v. 167, p. 619-31, 2004.

MARTINEZ, L. R.; CASADEVALL, A. Biofilm formation by Cryptococcus neoformans. Microbiol. Spectr, v. 3, p. 1-11, 2015. 
MARTINOTTO, C.; PAIVA, R.; SOARES, F. P.; SANTOS, B. R.; NOGUEIRA, R. C. Cagaiteira (Eugenia dysenterica DC.). Lavras-MG: Universidade Federal de Lavras, p. 121, 2008.

MARTINS, N. B. L; HENRIQUES, M.; SILVA, S. Activity of phenolic compounds from plant origin against Candida. Industrial Crops and Products, v. 74, p. 648-670, 2015.

MARTINY, D.; BUSSON, L.; WYBO, I.; EL HAJ, R. A.; DEDISTE, A.; VANDENBERG, O. Comparison of the Microflex LT and Vitek® MS systems for the routine identification of bacteria by Matrix-Assisted Laser Desorption-Ionization Time-Of-Flight Mass Spectrometry. J. Clin. Microbiol, v. 50, p. 1313-1325, 2012.

MASSONET, C.; ELDERE, J. V.; VANEECHOUTTE, M.; BAERE, T.; VERHAEGEN, J.; LAGROU, K. Comparison of VITEK 2 with ITS2-Fragment Length Polymorphism Analysis for Identification of Yeast Species. J. Clin. Microbiol, v. 42, p. 2209-2211, 2004.

MAZUTI SILVA, S. M.; GASCA SILVA, C. A.; FONSECA-BAZZO, Y. M.; Pérola Oliveira MAGALHÃES, P. O.; SILVEIRA, D. Eugenia dysenterica (Mart.) Ex DC. (cagaita): planta brasileira com potencial terapêutico. Infarma: Ciências Farmacêuticas, v. 27, p. 49-95, 2015.

MCCARTY, T. P.; PAPPAS, P. G. Invasive Candidiasis. Infectious Disease Clinics of North America, 2015.

MCCLELLAND, E. E.; HOBBS, L. M.; RIVERA, J.; CASADEVALL, A.; POTTS, W. K.; SMITH, J. M.; et al. The role of host gender in the pathogenesis of Cryptococcus neoformans infections. PLoS ONE, v. 8, 2013.

MCTAGGART, L. R.; LEI, E.; RICHARDSON, S. E.; HOANG, L.; FOTHERGILL, A.; ZHANG, S. X. Rapid Identification of Cryptococcus neoformans and Cryptococcus gattii by Matrix-Assisted Laser Desorption Ionization-Time of Flight Mass Spectrometry. J. Clin. Microbiol, v. 49, p. 3050-305, 2011.

MELHEM, M. S. C.; BERTOLETTI, A.; LUCCA, H. R. L.; SILVA, R. B. O.; MENEGHIN, F.A.; SZESZS, M. W. Use of the VITEK 2 system to identify and test the antifungal susceptibility of clinically relevant yeast species. Brazilian Journal of Microbiology, v. 44, p.1257-1266, 2013.

MEYER, W.; AANENSEN, D. M.; BOEKHOUT, T.; COGLIATI, M.; DIAZ, M. R.; ESPOSTO, M. C.; FISHER, M.; GILGADO, F.; HAGEN, F.; KAOCHAROEN, S.; LITVINTSEVA, A. P.; MITCHELL, T. G.; SIMWAMI, S. P.; TRILLES, L.; VIVIANI, M. A.;

KWON-CHUNG, J. Consensus multi-locus sequence typing scheme for Cryptococcus neoformans and Cryptococcus gattii. Medical Mycology, v. 47, p.561-570, 2009.

MEYER, W.; GILGADO, F.; NGAMSKULRUNGROJ, P.; TRILLES, L. H.; HAGEN, F.; CASTANEDA, E.; BOEKHOUT, T. Molecular typing of the Cryptococcus neoformans/Cryptococcus gattii species complex. In Cryptococcus: From human pathogen to model yeast. ASM, p. 327-357, 2011. 
MEZZARI, A.; WLIEBBELling, A. M. P.; FREITAS, G. S. O.; MAY, G. G; ALBÉ, G. C.; FILIK, H. P.; PORTICH, J. P.; KISSMANN, N.; BEHAR, P.; VILELA, R. M. M..Criptococose em um Hospital Público de Porto Alegre: dados epidemiológicos. J Infect Control, v. 2, p. 135-139, 2013.

MINAMI, P. S. Micologia: métodos laboratoriais de diagnóstico das micoses. Barueri-São Paulo: Manole, p. 199, 2003.

MITCHELL, T. G.; PERFECT, J. R. Cryptococcosis in the era of AIDS - 100 years after the discovery of Cryptococcus neoformans. Clin. Microbiol. Rev., v. 8, p. 515-548, 1995.

MORA, D. J.; FORTUNATO, L. R.; ANDRADE-SILVA, L. E.; FERREIRA-PAIM, K.; ROCHA, I. H.; VASCONCELOS, R. R.; et al. Cytokine Profiles at Admission Can Be Related to Outcome in AIDS Patients with Cryptococcal Meningitis. PLoS ONE, v. 10, 2015.

MORACE, G.; PERDONI, F.; BORGHI, E. Antifungal drug resistance in Candida species. Journal of Global Antimicrobial Resistance, v. 2, p. 254-259, 2014.

NÁGARAJHA, L. D.; KAVIYIL, J. E.; NIRUJOGI, R. S.; MUTHUSAMY, B.; PUTTAMALLESH, V. N.; SUBBANNAYYA, T. Proteogenomic analysis of pathogenic yeast Cryptococcus neoformans using high resolution mass spectrometry. Clin Proteomics, v.11, p.5, 2014.

NAMIQ, A. L.; TOLLEFSON, T.; FAN, F. Criptococcal parotifis presenting as a cystic parotid mass: Report of a case diagnosed by fine-neddle aspiration cytology. Diagn. Cytopathol, v. 33, p. 36-38, 2005.

NASSER, N.; NASSER FILHO, N.; VIEIRA, A. G. Criptococcose cutânea primária em paciente imunocompetente. An Bras Dermatol, v.86, p. 1178-1180, 2011.

NAYAK, J. B.; BRAHMBAHTT, M. N.; SAVALIA, C. V.; PAL, M.; BHANDERI, B. B. Cryptococcosis: A Garded Mycosis Threat. Journal of Veterinary Sciences, v. 3, p.101-112, 2010.

NEPPELENBROEK, K. H. et al. Identification of Candida species in the clinical laboratory: a review of conventional, commercial, and molecular techniques. Oral Diseases, v. 20, p. 32944, 2014.

NEUFELD, P. M. Manual de micologia médica: técnicas básicas de diagnóstico. Rio de Janeiro: Programa Nacional de Controle de Qualidade, p. 230, 1999.

NUCCI, M.; PERFECT, J. R. When primary antifungal therapy fails. Clin Infect Dis, v. 46, p. 1426-1433, 2008.

NWEZE, E. I.; KECHIA, F. A.; DIBUA, U. E.; EZE, C.; ONOJA, U. S. Isolation of Cryptococcus neoformans from environmental samples collected in southeastern nigeria. Revista do Instituto de Medicina Tropical de São Paulo, v. 57, 2015.

NYAZIKA, T.K.; et al.. Cryptococcus tetragattii as a major cause of cryptococcal meningitis among HIVinfected individuals in Harare, Zimbabwe, Journal of Infection, 2016. 
OKABAYASHI, K.; HASEGAWA, A.; WATANABE, T. Microreview: Capsule-associated genes of Cryptococcus neoformans. Mycopathologia, v. 163, p. 1-8, 2007.

OLIVEIRA, V. B.; YAMADA, L. T.; FAGG, C. W.; BRANDÃO, M. G. L. Native foods from Brazilian biodiversity as a source of bioactive compounds. Food Res Int, v.48, p. 170$179,2012$.

OLSZEWSKI, M. A.; NOVERR, M. C.; CHEN, G. H.; TOEWS, G. B.; COX, G. M.; PERFECT, J. R.; HUFFNAGLE, G. B. Urease expression by Cryptococcus neoformans promotes microvascular sequestration, thereby enhancing central nervous system invasion. Am J Pathol, v. 164, p.1761-1771, 2004.

PAL, M.; DAVE, P. Cryptococcosis: A global fungal zoonosis. Intas Polyvet, v. 7, p. 412420, 2006.

PANTOJA, M. G. L.; SILVEIRA, D. M. R.; SILVA, L. D. Disseminated cryptococcosis in a immuncompetent patient: case report. Rev. Paraense Med, 2009.

PARK, B. J.; et al. Estimation of the current global burden of cryptococcal meningitis among persons living with HIV/AIDS. AIDS, v. 23, p. 525-530, 2009.

PAULA, D. A. J.; ROSA E SILVA, L. K.; STAATS, C. C.; VAINSTEIN, M. H.; JOANONI, A. L. P.; NAZAKOTA, L.; DUTRA, V. Identification of genes expressed by Cryptococcus gattii during iron deprivation. Brazilian Journal of Microbiology, v.45, 2014.

PEDROSO, R. S. Caracterização molecular, virulência e suscetibilidade ao Fluconazol de espécies ambientais de Cryptococcus, antes e após inoculação em modelo murinho. Tese (Doutorado) - Faculdade de Ciências Farmacêuticas de Ribeirão Preto, São Paulo, p. 9$16,2008$.

PEDROSO, R. S.; CANDIDO, R. C. Diagnóstico Laboratorial da Criptococose. NewsLab, v. 77, p. 94-102, 2006

PEDROSO, R. S.; FERREIRA, J. C.; CANDIDO, R. C. The isolation and characterization of virulence factors of Cryptococcus spp.. from saprophytic sources in the city of Ribeirão Preto, São Paulo, Brazil. Microbiol Reserch, v. 164, p. 221-227, 2009.

PEDROSO, R. S; COSTA, K. R. C.; FERREIRA, J. C.; CANDIDO, R. C.. Avaliação da produção de melanina por espécies de Cryptococcus em quatro diferentes meios de cultura. Rev. Soc. Bras. Med. Trop, v.40, 2007.

PEMÁN, J.; CANTÓN, E.; ESPINEL-INGROFF, A. Antifungal drug resistance mechanisms. Expert Rev Anti Infect Ther, v. 7, p. 453-460, 2009.

PEREIRA, T. C. D.; BARROS, R. A. M. Cryptococcus neoformans e Cryptococcus gattii: perspectivas sobre a eco-epidemiologia e novos nichos ecológicos. Revista Facider, v. 1, 2012. 
PERFECT, J. R. Fungal diagnosis: how do we do it and can we do better? Curr. Med. Res. Opin, v. 29, p. 3-11, 2013.

PESSOA, C. C. B; SILVA, S. H. M; GOMES, F. S. Production of virulence factors in vitro by isolates of Cryptococcus neoformans and Cryptococcus gattii of clinical origin in Belém, Pará State, Brazil. Revista Pan-Amazônica de Saúde, v. 3, 2012.

PINA, G. O. Efeito alelopático do extrato aquoso foliar de Eugenia dysenterica DC.(Myrtaceae-cagaita) na germinação, crescimento e morfo-anatomia de Sesamum indicum L.(Pedaliaceae-gergelim) e Raphanus sativus L.(Brassicaceae-rabanete) [Dissertation]: Universidade de Brasília; 2008.

PINCUS, D. H.; ORENGA, S.; CHATELLIER, S. Yeast identification - past, present, and future methods. Medical Mycology, v. 45, p. 97-121, 2007.

POSTERARO, B.; VELlA, A.; COGLIATI, M.; CAROLI, E.; FlORIO, A. D.; POSTERARO, P.; SANGUINETTI; TORTORA, A. M. Matrix-Assisted Laser Desorption Ionization-Time of Flight Mass Spectrometry-Based Method for Discrimination between Molecular Types of Cryptococcus neoformans and Cryptococcus gattii. J. Clin. Microbiol. v. 50, p. 2472-2476, 2012.

PROENÇA, C. E. B.; GIBBS, P. E. Reproductive biology of eight sympatric Myrtaceae from Central Brazil. New Phytol, v. 126, p. 343-354, 1994.

QUEIROZ, J. P. A.; SOUSA, F. D. N.; LAGE, R. A.; IZAEL, M. A.; SANTOS, A. G. Criptococose - uma revisão bibliográfica. Acta Veterinaria Brasilica, v. 2, p. 32-38, 2008.

REOLON A.; PEREZ L. R. R.; MEZZARI, A. Prevalência de Cryptococcus neoformans nos pombos urbanos da cidade de Porto Alegre, Rio Grande do Sul. Jornal Brasileiro de Patologia e Medicina Laboratorial, v. 40, p. 29-33, 2004.

RIVERA, V.; GAVIRIA, M.; MUÑOZ-CADAVID, C.; CANO, L.; NARANJO, T.. Validation and clinical application of a molecular method for the identification of Cryptococcus neoformans/Cryptococcus gattii complex DNA in human clinical specimens. Brazilian Journal of Infectious Diseases, v. 19, 2015.

RODRÍGUEZ-TUDELA, J. L.; MARTINEZ-SUAREZ, J. V. Fluconazole and amphotericin B antifungal susceptibility testing by National Committee for Clinical Laboratory Standards broth macrodilution method compared with E-test and semiautomated broth microdilution test. J Clin Microbiol, v. 35, p. 336-337, 1997.

ROSA E SILVA, L. K.; STAATS, C. C.; GOULART, L. S.; MORELLO, L. G.; FUNGARO, M. H. P.; SCHRANK, A.; VAINSTEIN, M. H. Identification of novel temperature-regulated genes in the human pathogen Cryptococcus neoformans using representational difference analysis. Reserch Microbiology, v. 159, p. 221-229, 2008.

SALAS S. D.; BENNETT J. E.; KNOW-CHOUNG K. J.; PERFECT J. R.; WILLIAMSON P. R. Effect of the lacase gene, CNLAC1, on virulence of Cryptococcus neoformans. J Exp Med, v. 184, p. 377-386, 1996. 
SAMBROOK, J.; FRITSCH, E. F.; MANIATIS, T. Working with synthetic nucleotides probes Molecular cloning: a laboratory manual, 2nd ed., vol. 1. Cold Spring Harbor Laboratory Press, 1989.

SANCHINI, A.; et al. Molecular typing of clinical Cryptococcus neoformans isolates collected in Germany from 2004 to 2010. Med. Microbiol. Immunol, v. 203, p. 333-340, 2014.

SANGUINETTI, M.; POSTERARO, B.; LASS-FLÖRL, Candida Antifungal drug resistance among Candida species: mechanisms and clinical impact. Mycoses, v. 58, p. 2-13, 2015.

SANTANGELO, R.T.; NOURI-SORKHABI, M. H.; SORRELL, T. C.; CAGNEY, M.; CHEN, S. C.; KUCHEL, P. W.; et al. Biochemical and functional characterisation of secreted phospholipase activities from Cryptococcus neoformans in their naturally occurring state. $\mathbf{J}$ Med Microbiol, v. 48, p. 731-740, 1999.

SANTOS J. R. A.; HOLANDA, R. A.; FRASES, S.; BRAVIM, M.; ARAUJO, G. D. S.; SANTOS, P. C.; et al. Fluconazole Alters the Polysaccharide Capsule of Cryptococcus gattii and Leads to Distinct Behaviors in Murine Cryptococcosis. PLoS ONE, v. 9, 2014.

SANTOS, L. L.; FERREIRA, F. M.; LOPES, S. F.; CONDAS, L. A.; MURO, M. D.; LUGARINI, C. Pesquisa de Cryptococcus neoformans e Candida spp.. em excretas de psitacídeos e passeriformes cativos. Arq. Ciênc. Vet. Zool. Unipar, Umuarama, v. 12, p. 59, 2009.

SENADIM, S.; ALPAYDIN BASLO, S.; TEKIN GÜVELI, B.; DEDEI DARYAN, M.; KANTAROGLU, E.; OZTURK, O.; ATAKLI, D. A rare cause of cerebral venous thrombosis: cryptococcal meningoencephalitis. Neurol Sci, 2016.

SEVERO, C. B.; GAZZONI, A. F.; SEVERO, L. S. Criptococose pulmonar. J Bras Pneumol, v. 35, p. 1136-1144, 2009.

SILVA, R.; CHAVES, L.; NAVES, R. Caracterização de frutos e arvores de cagaita (Eugenia disenteria DC) no sudeste do estado de Goias, Brasil. Revista Brasileira de Fruticultura, v. 23, p. 330-334, 2001.

SORRELL, T. C..Cryptococcus neoformans variety gattii. Med Mycol, v. 39, p. 155-168, 2001.

SOUZA, P. M. et al. Plants from Brazilian Cerrado with Potent Tyrosinase Inhibitory Activity. Plos One, v. 7, n. 11, p. 1-7, 2012.

SOUZA, L. K. H.; FERNANDES, O. F. L.; PASSOS, X. S.; COSTA, M.; SOUZA JÚNIOR, A. H.; SILVA, M. R. R. Comparação dos Métodos de Identificação de Leveduras por Técnicas Manuais com o Método Automatizado Microscan Rapid Yeast Identification Panel. Revista de Patologia Tropical, v. 30, p. 13-29, 2001.

SOUZA, P. M. et al. Plants from Brazilian Cerrado with Potent Tyrosinase Inhibitory Activity. PLoS ONE, v. 7, n. 11, p. 1-7, 2012. 
SPRINGER, D. J.; CHATURVEDI, V.. Projecting global occurrence of Cryptooccus gattii. Emerg Infect Dis, v. 16, p. 14-20, 2010.

SPITZER, E. D.; SPITZER, S. G. Use of a dispersed repetitive DNA element to distinguish clinical isolates of Cryptococcus neoformans. Journal of Clinical Microbiology, v. 30, p. 1094-1097, 1992.

STEENBERGEN, J. N.; CASADEVALL, A. The origin and maintenance of virulence for the human pathogenic fungus Cryptococcus neoformans. Microbes and Infection, v. 5, p. 667$675,2003$.

STEENBERGEN, J.N.; NOSANCHUK, J. D.; MALLIARIS, S. D.; CASADEVALL, A. Cryptococcus neoformans virulence is enhanced after growth in the genetically malleable host Dictyostelium discoideum. Infection and Immunity, v.71, p. 4862-4872, 2003.

ST GERMAIN, G.; BEAUCHESNE, D. Evaluation of the MicroScan Rapid Yeast Identification panel. J Clin Microbiol., v. 29, p. 2296- 2299, 1991.

TAPIA, C.; CORREA, N. Genero Cryptococcus. Revista Chilena de Infectología, v. 31, p. 719-720, 2014.

TEODORO, V. L. I.; GULlO, F. P.; SARDI, J. C. O. S.; TORRES, E. M.; FUSCOALMEIDA, A. M.; MENDES GIANNIMI, M. J. S. Environmental isolation, biochemical identification, and antifungal drug susceptibility of Cryptococcus species. Rev. Soc. Bras. Med. Trop, v.46, 2013.

TELLO, M.; GUTIÉRREZ, E.; et al. Criptococosis. Revista Médica Risaralda, v.19, p. 147$153,2013$.

TRILLES, L.; LAZÉRA, M. S.; WANKE, B.; OLIVEIRA, R. V.; BARBOSA, G. G.; NISHIKAWA, M. M. Regional pattern of the molecular types of Cryptococcus neoformans and Cryptococcus gattii in Brazil. Mem Inst Oswaldo Cruz, v. 103, p. 455-462, 2008.

TSENG, H. K.; LIU, C. P.; HO, M, W.; LU, P.L.; LO, H.J.; LIN, Y.H.; et al. Microbiological, Epidemiological, and Clinical Characteristics and Outcomes of Patients with Cryptococcosis in Taiwan, 1997-2010. PLoS ONE v. 8, 2013.

VENDRÚSCOLO, G. S.; MENTZ, L. A. Levantamento etnobotânico das plantas utilizadas como medicinais por moradores do bairro Ponta Grossa, Porto Alegre, Rio Grande do Sul, Brasil. Iheringia, Ser. Bot., v. 61, p. 83-103, 2006.

VERON, V.; SIMON, S.; BLAMCHET, D.; AZNAR, C. Real-time polymerase chain reaction detection of Cryptococcus neoformans and Cryptococcus gattii in human samples. Diagn Microbiol Infect Dis, v. 65, p. 69-72, 2009.

VICTORIA, F. N., et al. Essential oil of the leaves of Eugenia uniflora L.: Antioxidant and antimicrobial properties. Food and Chemical Toxicology, v. 50, p. 2668-2674, 2012.

XAVIER, M. O.; OLIVEIRA, F. M.; SEVERO, L. C. Diagnóstico laboratorial das micoses pulmonares. J Bras Pneumol, v. 35, p. 907-919, 2009. 
XU, J.; VILGALYS, R.; MITCHELL, T. G. Multiple gene genealogies reveal recent dispersion and hybridization in the human pathogenic fungus Cryptococcus neoformans. Molecular Ecology, v. 9, p. 1471-1481, 2000.

ZAITZ, C. et al. Compêndio de Micologia Médica. 2. Rio de Janeiro: GUANABARA KOOGAN, 2010.

ZARAGOZA, O.; et al. Equatorial ring-like channels in the Cryptococcus neoformans polysaccharide capsule. FEMS Yeast Res. v.6, p. 662-666, 2006.

WALRAVEN, C.J.; GERSTEIN, W.; HARDISON, S. E.; WORMLEY, F.; LOCKHART, S. R.; HARRIS, J. R.; et al. Fatal Disseminated Cryptococcus gattii Infection in New Mexico. PLoS ONE. V.6, 2011.

WANGY, J.; ZENG, Y.; LUO, W.; XIE, X.; LI, S. The Role of Cryptococcus in the Immune System of Pulmonary Cryptococcosis Patients. PLoS ONE, v.10, 2015.

WANG, Y.; AISEN, P.; CASADEVALL, A. Cryptococcus neoformans melanin and virulence: mechanism of action. Infect Imun, v. 63, p. 3131-3136, 1995.

WANG, Y.; CASADEVALL, A. Decreased susceptibility of melanized Cryptococcus neoformans to UV light. Appl Environ Microbiol, v. 60, p. 3864-3866, 1994.

WONG, B.; PERFECT, J. R.; BEGGS, S.; WRIGHT, K. A. Production of hexitol D-mannitol by Cryptococcus neoformans in vitro and in rabbits with experimental meningitis. Infection and Immunity, v. 58, p. 1664-1670, 1990.

YAMAMURA, A. A. M.; FREIRE, R. L.; YAMAMURA, M. H.; TARODA, A.; FELIX, A. Estudo dos nichos ecológicos de leveduras patogênicas das Crytocococcus neoformans e $C$. gattii na cidade de Londrina, PR. Semina: Ciências Agrárias, v. 34, p. 793-803, 2013. 


\section{ANEXO}

FACULDADE DE CIÊNCIAS DA
SAÚDE DA UNIVERSIDADE DE
BnB
BRASÍLIA - CEPIFS-UNB

\section{PARECER CONSUBSTANCIADO DO CEP}

\section{DADOS DO PROJETO DE PESQUISA}

Título da Pesquisa: Efeito de Eugenia dysenterica DC. (Hexachlamys macedoi Legrand) sobre isolados clínicos de Cryptococcus spp.

Pesquisador: Yanna Karla de Medeiros Nóbrega

Área Temática:

Versão: 2

CAAE: 51353915.1 .0000 .0030

Instituição Proponente: FUNDACAO UNIVERSIDADE DE BRASILIA

Patrocinador Principal: Financiamento Próprio

\section{DADOS DO PARECER}

Número do Parecer: 1.385 .224

\section{Apresentação do Projeto:}

Ha duas especies patogenicas de Cryptococcus, Cryptococcus neoformans (sorotipo Ae D) e Cryptococcus gattii (sorotipos B/C - Cryptococcus neoformans var. gattii). Estas especies sao consideradas emergentes e cosmopolitas, encontradas principalmente no solo, em aves e em arvores. Sua transmissao ocorre atraves do sistema respiratorio e, eventualmente, e disseminado para o cerebro atraves do sistema nervoso central, atravessando a barreira encefalica, causando muita vezes meningoencefalite fatal (BAHN E JUNG, 2013; LIU et al., 2012).O Cryptococcus gattii e a especie, em particular, mais perigosa, por sua capacidade de atacar individuos saudaveis (Bahn e Jung, 2013). Ja o C. neoformans apresenta carater geralmente oportunista, sendo vinculado a presenca de imunossupressao, causada principalmente pelo virus da imunodeficiencia humana (HIV) (LIU et al., 2012). Alem do HIV, outros fatores estao associados a criptococose, entre eles: o uso de medicacoes imunosupressoras (corticosteroides, inibidores de calcineurina, agentes citotoxico e anticorpos monoclonais), transplantes de orgaos e tecidos, doencas autoimunes e outras doencas cronicas (SLOAN E PARRIS, 2014).Mundialmente, cerca de 1 milhao de casos novos de infeccoes criptococicas em individuos infectados com HIV, ocorre a cada ano, resultando em 625.000 mortes. Nos paises, onde as condicoes de saude sao extremamente precarias, como em grande parte da Africa Subsaariana, as infeccoes fatais por Cryptococcus spp. atingem indices

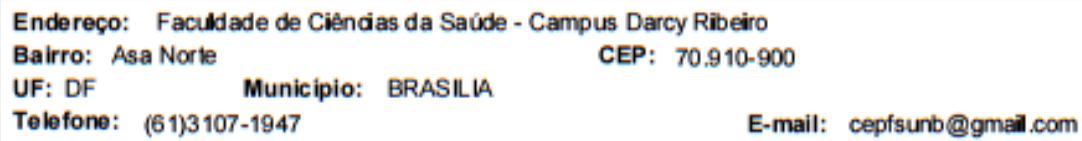




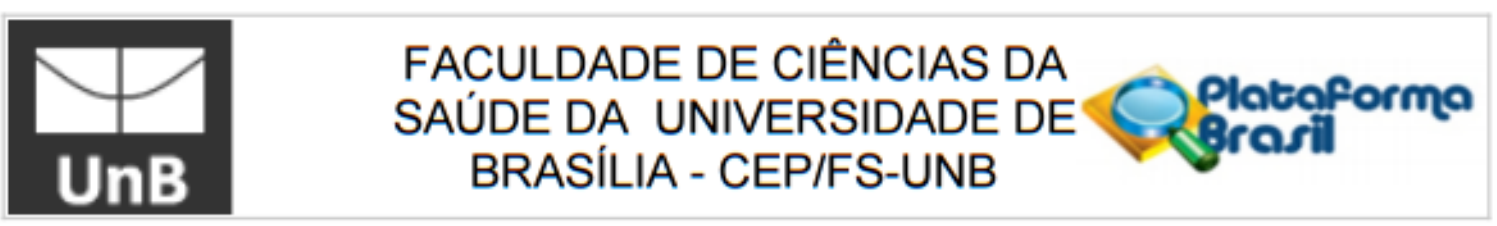

Con§nuaçăo do Paøecer: 1.385 .224

alarmantes, superando o numero de obitos provocados por doencas graves como a tuberculose. Entretanto, em paises emergentes e desenvolvidos, o numero de casos de infeccoes por Cryptococcus spp. tem reduzido nos ultimos anos, fato atribuido a disponibilidade generalizada das terapias antiretrovirais (CDC, 2014).Com relacao ao tratamento das infeccoes causadas por Cryptococcus spp, o numero de opcoes terapeuticas disponiveis e bastante limitado quando comparado a gravidade e relevancia para a saude publica desta infeccao. Desta forma, a aplicacao de metodologias que permitam a determinacao das diversidades genomicas das especies de Cryptococcus spp. e a investigacoes de mecanismos de virulencia associadas a estas especies, tem aumentado com proposito de identificar novos alvos terapeuticos no combate da criptococose (BAHN E JUNG, 2013). Diante destas circunstancias, estrategias farmacologicas vem sendo utilizadas, representadas pela producao de novas formulacoes de antifungicos, combinacoes terapeuticas entre os antifungicos disponiveis e tambem terapias alternativas usando principios ativos obtidos de fontes naturais, materiais sinteticos e materiais polimericos (SPAMPINATO E LEONARDI, 2013). Entre as fontes naturais, os extratos de plantas sao particularmente muito atrativos para a descoberta de futuros compostos terapeuticos e isto se deve principalmente a presenca de diversas substancias quimicas com diferentes propriedades farmacologicas, dentre elas a atividade antifungica (NEGRI et al., 2014).Muito produtos naturais, tem demonstrados propriedades antifungicas contra Cryptococcus spp. Recentemente, ISHIDA et al. (2014) relataram a utilizacao de nanoparticulas de prata contra Cryptococcus neoformans e especies de Candida. Mokoka et al. (2013) utilizaram extrato hexano da planta africana, Maytenus undata (Celastraceae), tambem demonstraram efeito inibitorio contra Cryptococcus neoformans. Funari et al. (2012) apresentaram dados referentes a atividade de extratos, fracoes e compostos puros, de plantas do genero Lippia, contra especies de Candida e Cryptococcus, exibindo a potencialidade destes agentes especialmente contra Cryptococcus neoformans. Alem disso, tambem foi revelada atividade anti-criptococica de compostos isolados como triterpenos (MOKOKA et al., 2013) e flavonoides (DOS S GRECCO et al., 2014).A atividade anti-criptococica de Eugenia dysenterica DC. (Hexachlamys macedoi Legrand) ja foi demonstrada por Costa et al (2000) em seus oleos essenciais extraidos de suas folhas. Esta arvore frutifera exotica, esta presente na Caatinga, Cerrado e Mata Atlantica (SOBRAL et al., 2013) pertencente a familia Myrtaceae e e conhecida como "cagaiteira" ou "caigata" (CARDOSO et al., 2011). Os seus frutos sao comumente utilizados in natura ou para obtencao de bebidas, sorvetes, sucos e geleias. Da polpa do fruto tambem sao produzidos vinagre e alcool e suas folhas e cascas sao utilizadas popularmente como antidiarreico, para diabetes e para ictericia (JORGE et al., 2010). Quanto a suas atividade biologicas, ja foram

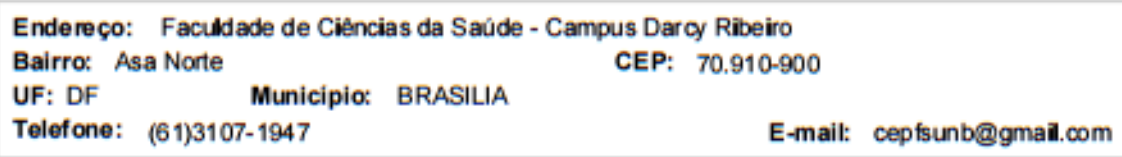




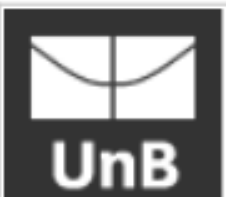

\section{FACULDADE DE CIÊNCIAS DA SAÚDE DA UNIVERSIDADE DE BRASÍLIA - CEP/FS-UNB}

Conanuaçåo do Parecer: 1.385.224

demonstradas atividade antimicrobiana de compostos fenolicos isolados de sua semente (JORGE et al., 2010), atividade antiviral contra rotavirus atribuida a presenca de taninos, flavonoides, terpenos e saponinas isolados do extrato etanolico de folhas (CECILIO et al., 2012) e atividade antifungica por Costa et al., 2000. No entanto, a atividade biologica do extrato aquoso das folhas ainda nao foi relatado.

Metodologia: - Obtencao do material microbiologico As amostras de Cryptococcus spp. utilizadas neste trabalho serao cedidas pelo Nucleo de Parasitologia e Micologia (NPM) do Laboratorio Central de Saude Publica do Distrito Federal (LACEN-DF). A identificacao preliminar dos Cryptococcus spp. consistira em exame direto com tinta nanquim para visualizacao da capsula e/ou cultura em Agar Niger a 25oC. Apos identificacao as amostras serao mantidas viaveis para testes seguintes atraves de cultivo em agar Sabouraud a $370 \mathrm{C}$ e serao congeladas em glicerol 10\% a - 200C (MINAMI, 2003).

- Identificacao por espectrometria de massa MALDI-TOF A fim de confirmar a identificacao fenotipica, os isolados de Cryptococcus spp. serao analisados por

espectrometria de massa na estacao de preparacao Vitek MS (BioMerieux®e, Franca). Para isto, os isolados serao preparados usando metodo direto de extracao. As colonias serao aplicadas em suporte para inoculacao/identificacao (BioMerieux(2), Franca) e em seguida adicionado $0,5 \mathrm{~L}$ de acido formico ( $25 \%$ [vol / vol] - BioMerieux(2), Franca). Apos secagem a temperatura ambiente, $1 \mathrm{~L}$ de matriz de acido -ciano-4hidroxicinamico (3.1\% [peso / vol]) - BioMerieux, Franca) sera aplicado e seco a temperatura ambiente antes da analise por espectrometria de massa. A analise dos resultados sera realizada utilizando o banco de dados SARAMIS.

4.2. Determinacao do perfil de sensibilidade dos isolados de Cryptococcus spp. A determinacao do perfil de sensibilidade dos isolados de Cryptococcus spp., diante aos antifungicos comumente utilizados na clinica sera baseada nas normas M27-A2 (2002) do Clinical and Laboratory Standards Institute (CLSI) dos Estados Unidos da America. Esta norma descreve a tecnica de microdiluicao em caldo, a qual fornece a concentracao inibitoria minima (CIM), apos 24 horas de incubacao e requer tambem a utilizacao de inoculo fungico ( 1 × 106 a $5 \times 106$ celulas de leveduras $/ \mathrm{mL}$ ); meio RMPI-1640, placas de microtitulacao esterieis de fundo chato com 96 pocos e solucoes padroes de agentes antifungicos preparadas em solventes adequados.4.3. Teste de atividade antifungica

- Obtencao do material vegetal Para o teste de atividade antifungica sera utilizada extrato aquoso das folhas de Eugenia dysenterica, obtido da regiao do Cerrado em Brasilia e entorno. Apos secagem em estufa com circulacao de ar, em temperatura inferior a $40 \mathrm{oC}$, o material sera pulverizado em moinho de facas e extraidos por maceracao passiva. Apos extracao a quase

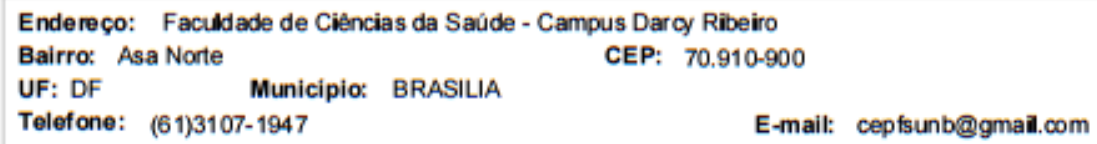




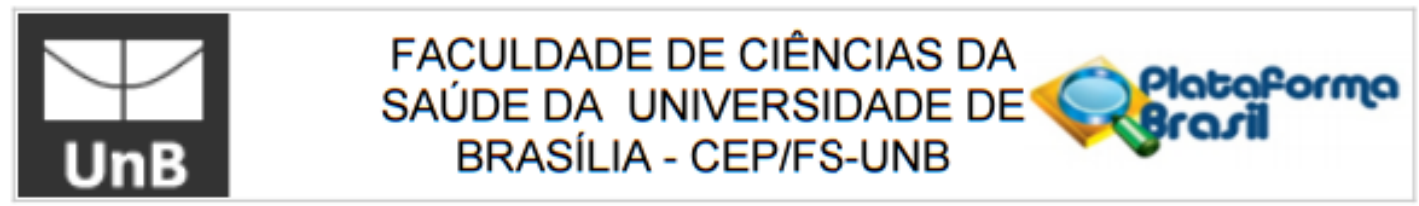

Conฎnuaçăo do Parecer: 1.385.224

completo esgotamento, as solucoes extrativas obtidas serao concentradas em rotavapor a temperatura inferior a 40 oC (CORREIA et al., 2008).

- Teste da Atividade Antifungica As tecnicas usadas no teste da atividade antifungica para o extrato serao: disco difusao e microdiluicao em caldo. As etapas para a realizacao da tecnica de disco difusao consistem em: preparacao da solucao do extrato a ser testado (concentracao final de $100 \mathrm{mg} / \mathrm{mL}$ ); preparacao dos discos de papel, onde serao impregnados a solucao do extrato; preparacao do inoculo fungico ( $1 \times 106$ a $5 \times$ 106 celulas de leveduras $/ \mathrm{mL}$ ) e aplicacao dos discos no agar Mueller-Hinton. A realizacao da tecnica de microdiluicao sera de acordo com a norma M27-A2 (2002) do CLSI, com a seguinte modificacao: os agentes antifungicos serao substituidos pelos extratos brutos.

\section{Objetivo da Pesquisa:}

Objetivo geral: Avaliar o efeito inibitorio de extrato aquoso das folhas de Eugenia dysenterica DC. (Hexachlamys macedoi Legrand) sobre isolados clinicos de Cryptococcus spp. Objetivos especificos: Confirmar, por espectrometria de massa - MALDI-TOF, a identificacao fenotipica dos diferentes isolados clinicos de Cryptococcus spp.

Determinar o perfil de sensibilidade de isolados de Cryptococcus spp. frente aos antifungicos comumente utilizado na clinica; Testar extrato aquoso das folhas de Eugenia dysenterica quanto a atividade inibitoria frente aos isolados de Cryptococcus spp.

\section{Avaliaçăo dos Riscos e Beneficios:}

De acordo com os pesquisadores, os doadores fontes de onde estes materiais clinicos serao isolados nao terao sua identidade revelada, e esta doacao de material nao acarretara nenhum risco direto.

Este projeto tem como foco avaliar o efeito da Eugenia dysenterica sobre Cryptococcus spp. que sao fungos patogenicos com elevada incidencia no pais. A Eugenia dyserterica, assim como varias outras plantas do cerrado brasileiro, sao fontes de compostos quimicos com atividade biologica variaveis com grande potencialidade para o desenvolvimento de novos farmacos. Assim, espera-se que a determinacao do efeito inibitorio de E. dysenterica sobre o Cryptococcus spp. seja o primeiro passo no desenvolvimento de fitoterapicos ou na identificacao de metabolitos secundarios, com atividades antifungicas, que poderao ser utilizados como materia prima para novos farmacos. Almeja-se tambem caracterizar de forma mais especifica as especies de Cryptococcus e tracar seu perfil de susceptibilidade aos antifungicos comumente utilizado na clinica. Isto contribuira para o melhor enterdimento da patologia causada por este microorganismo, bem como para descricao rapida e precisa de novos patogenos emergentes, para

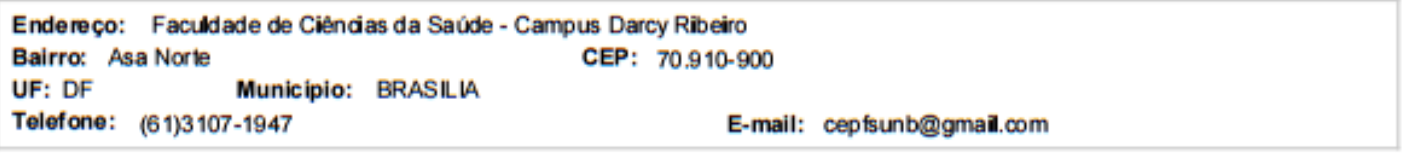




FACULDADE DE CIÊNCIAS DA
SAÚDE DA UNIVERSIDADE DE Platoforma
BnB

Conミnuaçăo do Parecer: 1.385 .224

o sucesso terapeutico e subsequente reducao das taxas de morbidade e mortalidade causadas pela criptococcose.

Comentários e Consideraçōes sobre a Pesquisa:

A presente pesquisa e referente ao projeto de mestrado do Jorge Antonio Chamon Junior sob a orientacao da Profa. Dra. Yanna Karla de Medeiros Nobrega apresentado ao Programa de Pos-Graduacao em Ciencias Farmaceuticas da Faculdade de Ciencias da Saude - Universidade de Brasilia. Trata-se de um estudo in vitro que visa Avaliar o efeito inibitorio de extrato aquoso das folhas de Eugenia dysenterica DC. (Hexachlamys macedoi Legrand) sobre isolados clinicos de Cryptococcus spp.

O documento que contem o projeto encontra-se ainda com as correcoes sugeridas pela orientadora. Ainda, foi solicitado a dispensa do TCLE, uma vez que, isolados clinicos de Cryptococcus spp., provenientes de materiais biologicos de pacientes com suspeita clinica de criptococcose, atendidos nas unidades de saude da rede publicos do Distrito Federal serao provenientes do LACEN-DF. Segundo os autores, o LACEN-DF garante sigilo absoluto dos resultados, tornando-se detentor das amostras. Neste projeto nao serao utilizados dados referentes aos pacientes, nao acarretando nenhum risco aos mesmos. No entanto, nao fci apresentado nenhum documento que comprove a colaboracao com o Nucleo de Parasitologia e Micologia (NPM) do Laboratorio Central de Saude Publica do Distrito Federal (LACEN-DF).

\section{Considerações sobre os Termos de apresentação obrigatória:}

Foram utilizados os seguintes documento para emissão do presente parecer:

1- Informaçōes Básicas do Projeto: PB_INFORMAÇŌES_BÁSICAS_DO_PROJETO_533004.pdf, postado em 04/01/2016;

2- Termo_concordancia_LACEN.pdf, postado em 04/01/2016

3-Resposta_ao_Parecer_Consubstanciado_emitido_pelo_CEP_29_12_15.docx, postado em 29/12/2015;

4- Projeto Detalhado / Brochura Investigador: Projeto_Jorge_Chamon_revisado_29_12_15.doc, postado em 29/12/2015.

\section{Recomendaçōes:}

Năo se aplica.

Conclusōes ou Pendências e Lista de Inadequaçōes:

Solicita-se:

Endereço: Faculdade de Ciências da Saúde - Campus Darcy Ribeiro

Bairro: Asa Norle CEP: $70.910-900$

UF: DF Municipio: BRASILIA

Telefone: (61)3107-1947

E-mail: cepfsunb@gmail.com 


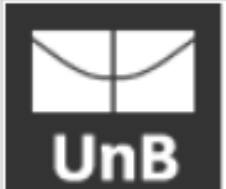

\section{FACULDADE DE CIÊNCIAS DA SAÚDE DA UNIVERSIDADE DE BRASÍLIA - CEP/FS-UNB}

Conفnuaçào do Parecer: 1.385.224

1- O documento contendo o projeto encontra-se ainda em fase de estruturacao, uma vez que a versao encaminhada ao CEP esta com correcoes ao longo do texto. Solicita-se ajustar esse documento. PENDÊNCIA ATENDIDA

2 - Nao foi apresentado nenhum documento que comprove a colaboracao com o Nucleo de Parasitologia e Micologia (NPM) do Laboratorio Central de Saude Publica do Distrito Federal (LACEN-DF). Solicita-se apresentar termo de ciencia dessa colaboracao.PENDÊNCIA ATENDIDA

3 - Inserir o LACEN como instituicao co-participante na Plataforma Brasil de forma que esteja vinculado ao CEP-FEPECS.PENDÊNCIA ATENDIDA

4 - De acordo com o cronograma de execucao, o projeto ja foi iniciado, solicita-se esclarecer. PENDÊNCIA ATENDIDA

5 - Solicita-se esclarecer se o presente projeto tera acesso ao material biologico do individuo ou apenas ao isolado clinico do criptococos. PENDÊNCIA ATENDIDA

As pendências foram sanadas năo existindo óbices éticos.

\section{Considerações Finais a critério do CEP:}

De acordo com a Resoluçăo 466/12 CNS, itens X.1.- 3.b. e XI.2.d, os pesquisadores responsáveis deverăo apresentar relatórios parcial semestral e final do projeto de pesquisa, contados a partir da data de aprovaçăo do protocolo de pesquisa.

Este parecer fol elaborado baseado nos documentos abaixo relacionados:

\begin{tabular}{|c|c|c|c|c|}
\hline Tipo Documento & Arquivo & Postagem & Autor & Situaçăo \\
\hline $\begin{array}{l}\text { Informaç̋̋es Básicas } \\
\text { do Projeto }\end{array}$ & $\begin{array}{l}\text { PB_INFORMAÇŌES_BÁSICAS_DO_P } \\
\text { ROJETO 533004.pdf }\end{array}$ & $\begin{array}{c}04 / 01 / 2016 \\
17: 56: 24\end{array}$ & & Aceito \\
\hline Outros & Termo_concordancia_LACEN.pdf & $\begin{array}{l}04 / 01 / 2016 \\
17: 45 ; 15\end{array}$ & $\begin{array}{l}\text { Yanna Karla de } \\
\text { Medeiros Nóbrega }\end{array}$ & Aceito \\
\hline Outros & $\begin{array}{l}\text { Resposta_ao_Parecer_Consubstanciad } \\
\text { o_emitido_pelo_CEP_29_12_15.docx }\end{array}$ & $\begin{array}{l}29 / 12 / 2015 \\
13: 05: 44\end{array}$ & $\begin{array}{l}\text { Yanna Karla de } \\
\text { Medeiros Nóbrega }\end{array}$ & Aceito \\
\hline $\begin{array}{l}\text { Projeto Detalhado / } \\
\text { Brochura } \\
\text { Investigador }\end{array}$ & $\begin{array}{l}\text { Projeto_Jorge_Chamon_revisado_29_1 } \\
\text { 2_15.doc }\end{array}$ & $\begin{array}{c}29 / 12 / 2015 \\
13: 04: 48\end{array}$ & $\begin{array}{l}\text { Yanna Karla de } \\
\text { Medeiros Nóbrega }\end{array}$ & Aceito \\
\hline Orçamento & orcamento_projeto.pdf & $\begin{array}{l}27 / 11 / 2015 \\
09: 44: 52\end{array}$ & $\begin{array}{l}\text { Yanna Karla de } \\
\text { Medeiros Nóbrega }\end{array}$ & Aceito \\
\hline Outros & carta_encaminhamento_projeto.pdf & $\begin{array}{c}27 / 11 / 2015 \\
09: 42: 58\end{array}$ & $\begin{array}{l}\text { Yanna Karla de } \\
\text { Medeiros Nóbrega }\end{array}$ & Aceito \\
\hline Outros & Termo_responsabilidade_yanna.pdf & $\begin{array}{l}27 / 11 / 2015 \\
09: 42: 25\end{array}$ & $\begin{array}{l}\text { Yanna Karla de } \\
\text { Medeiros Nóbrega }\end{array}$ & Aceito \\
\hline
\end{tabular}

Endereço: Faculdade de Ciências da Saúde - Campus Darcy Ribeiro

Bairro: Asa Norte CEP: 70.910-900

UF: DF Municipio: BRASILIA

Telefone: (61)3107-1947

E-mail: cepfsunb@gmail.com 


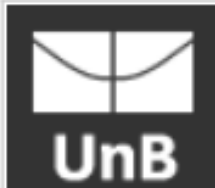

\section{FACULDADE DE CIÊNCIAS DA SAÚDE DA UNIVERSIDADE DE BRASÍLIA - CEP/FS-UNB}

Con§nuaçào do Parecer: 1.385 .224

\begin{tabular}{|c|c|c|c|c|}
\hline $\begin{array}{l}\text { Projeto Detalhado / } \\
\text { Brochura } \\
\text { Investigador }\end{array}$ & Projeto_Jorge_Chamon.doc & $\begin{array}{c}20 / 11 / 2015 \\
11: 59: 53\end{array}$ & \begin{tabular}{|l|} 
Yanna Karla de \\
Medeiros Nóbrega
\end{tabular} & Aceito \\
\hline Outros & Termo_responsabilidade_Amabel.pdf & $\begin{array}{c}20 / 11 / 2015 \\
11: 54: 40\end{array}$ & $\begin{array}{l}\text { Yanna Karla de } \\
\text { Medeiros Nóbrega }\end{array}$ & Aceito \\
\hline Outros & Termo_responsabilidade_Jorge.pdf & $\begin{array}{c}20 / 11 / 2015 \\
11: 54: 15\end{array}$ & $\begin{array}{l}\text { Yanna Karla de } \\
\text { Medeiros Nóbrega }\end{array}$ & Aceito \\
\hline Outros & Lattes_Jorge.pdf & $\begin{array}{c}20 / 11 / 2015 \\
11: 50: 25\end{array}$ & $\begin{array}{l}\text { Yanna Karla de } \\
\text { Medeiros Nóbrega }\end{array}$ & Aceito \\
\hline Outros & Lattes_Amabel.pdf & $\begin{array}{c}20 / 11 / 2015 \\
11: 50: 02\end{array}$ & $\begin{array}{l}\text { Yanna Karla de } \\
\text { Medeiros Nóbrega }\end{array}$ & Aceito \\
\hline Outros & Lattes_Yanna.pdf & $\begin{array}{c}20 / 11 / 2015 \\
11: 49: 37\end{array}$ & $\begin{array}{l}\text { Yanna Karla de } \\
\text { Medeiros Nóbrega }\end{array}$ & Aceito \\
\hline Folha de Rosto & Folha_de_rosto_assinada_final.pdf & $\begin{array}{c}20 / 11 / 2015 \\
11: 44: 28\end{array}$ & $\begin{array}{l}\text { Yanna Karla de } \\
\text { Medeiros Nóbrega }\end{array}$ & Aceito \\
\hline
\end{tabular}

\section{Situação do Parecer:}

Aprovado

Necessita Apreciação da CONEP:

Năo

BRASILIA, 07 de Janeiro de 2016

Assinado por:

Keila Elizabeth Fontana

(Coordenador)

Endereço: Faculdade de Ciênaias da Saúde - Campus Darcy Rỉbeiro

Bairro: Asa Norte CEP: $70.910-900$

UF: DF

Municipio: BRASILIA

Telefone: (61)3107-1947

E-mail: cepfsunb@gmail.com

Pagina 07 de 07 